\title{
Total Synthesis of Isoprekinamycin: Structural Evidence for Enhanced Diazonium Ion Character and Growth Inhibitory Activity Towards Cancer Cells
}

\section{Supporting Information}

Table of contents

Page

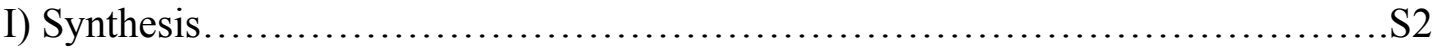

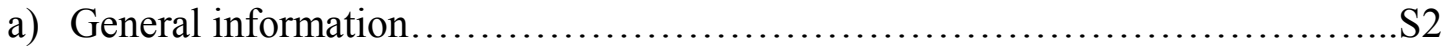

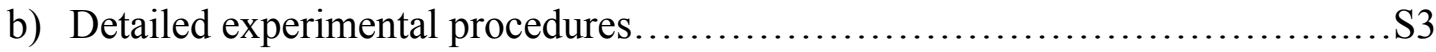

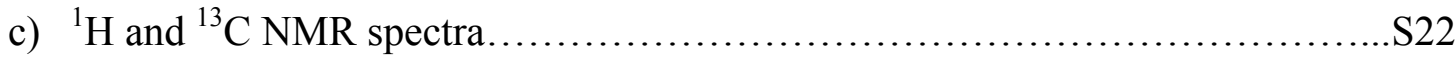

II) Comparison of natural and synthetic isoprekinamycin....................... 56

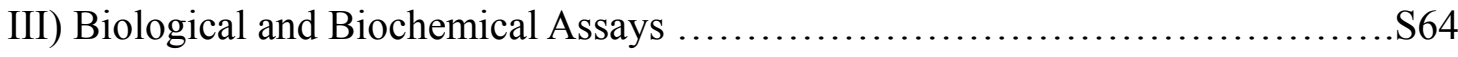

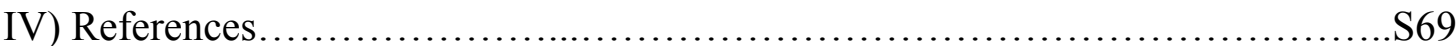




\section{I) Synthesis}

\section{a) General information}

${ }^{1} \mathrm{H}$ NMR spectra were recorded on a Brüker AVANCE500 (500 MHz), Brüker AC300 (300 MHz) and Brüker AVANCE300 (300 MHz) NMR spectrometer. Chemical shifts are reported in parts per million (ppm) relative to tetramethylsilane (TMS). The following abbreviations are used for NMR peak multiplicities: s, singlet; $d$, doublet; $t$, triplet; $q$, quartet; dd, doublet of doublets; dt, doublet of triplet; m, multiplet; b, broad; w, weak. ${ }^{13} \mathrm{C}$ NMR spectra were broad band decoupled and recorded on a Brüker AVANCE500 (125.8 MHz), Brüker AC300 (75.5 MHz) and Brüker AVANCE300 (75.5 MHz) NMR spectrometer using the carbon signal of the deuterated solvent as the internal standard. HMQC and HMBC experiments were performed on a Brüker AVANCE500 spectrometer. IR spectra were determined on a Perkin-Elmer RX I FT-IR spectrometer as $\mathrm{KBr}$ discs unless otherwise indicated. High/low resolution electron impact (EI) mass spectra (MS) were measured by the WATSPEC Mass Spectrometry Facility (Department of Chemistry, University of Waterloo, Waterloo, Ontario, Canada) and the McMaster Regional Center for Mass Spectrometry (Department of Chemistry, McMaster University, Hamilton, Ontario, Canada). Gas chromatography-mass spectrometry (GC-MS) was performed on a HP GCD 1800 with a column (HP5) length of $30.0 \mathrm{~m}$ and diameter of $0.25 \mathrm{~mm}$. The following temperature program was applied: initial temperature $70{ }^{\circ} \mathrm{C}$, rising rate 10 ${ }^{\circ} \mathrm{C} /$ minute, final temperature $265{ }^{\circ} \mathrm{C}$ held for 20.0 minutes. Elemental analyses were performed by the M-H-W Laboratories (Phoenix, Arizona, USA).

Anhydrous THF and $\mathrm{Et}_{2} \mathrm{O}$ were freshly distilled from sodium/benzophenone under nitrogen prior to use. Anhydrous $\mathrm{CH}_{2} \mathrm{Cl}_{2}$ was freshly distilled from $\mathrm{CaH}_{2}$ under nitrogen prior to use. All commercial reagents were purchased from Aldrich Chemical Co., Strem 
Chemicals Inc., Alfa Aesar, Lancaster Synthesis Ltd. or BDH Inc. and were used as received unless otherwise indicated. Deionized water was supplied by a Biolab vertical series reverse osmosis system.

The $-78^{\circ} \mathrm{C}$ and $0{ }^{\circ} \mathrm{C}$ designations refer to dry ice/acetone and ice/water slush respectively. Flash column chromatography was carried out using the Merck silica gel (70-230 mesh)

and SiliCycle silica gel (60 ̊̊). Reactions were magnetically stirred and monitored by thin layer chromatography (TLC) with Merck pre-coated silica gel plates (silica gel 60 $\mathrm{F}_{254}$ on aluminum sheet). All reported yields are isolated yields.

\section{b) Detailed experimental procedures}

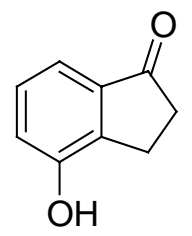

\section{4-Hydroxy-2, 3-dihydroindan-1-one ${ }^{1}$}

$\mathrm{AlCl}_{3}(58.19 \mathrm{~g}, 0.436 \mathrm{~mol})$ and $\mathrm{NaCl}(12.03 \mathrm{~g}, 0.256 \mathrm{~mol})$ were mixed and heated in an oil bath. When the bath temperature was about $150{ }^{\circ} \mathrm{C}$, dihydrocoumarin $(10 \mathrm{~mL}, 0.079$ mol) was added slowly while the bath temperature was maintained between $150{ }^{\circ} \mathrm{C}$ and $180{ }^{\circ} \mathrm{C}$. The bath temperature was then raised to $200{ }^{\circ} \mathrm{C}$ and the mixture was stirred for 1 hour. The mixture was cooled to room temperature and quenched with $100 \mathrm{~g}$ crushed ice and $50 \mathrm{ml}$ conc. $\mathrm{HCl}$ at $0{ }^{\circ} \mathrm{C}$. The suspension was stirred at room temperature for 30 minutes and the crude product $(9.688 \mathrm{~g})$ was obtained as a gray solid upon filtration. 


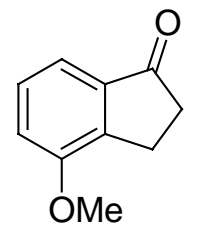

\section{4-Methoxy-2,3-dihydroindan-1-one}

To a solution of the crude indanone $(9.688 \mathrm{~g}, 0.065 \mathrm{~mol})$ and $\mathrm{K}_{2} \mathrm{CO}_{3}(56.94 \mathrm{~g}, 0.411 \mathrm{~mol})$ in acetone $(667 \mathrm{~mL})$ was added $\mathrm{Me}_{2} \mathrm{SO}_{4}(45.36 \mathrm{~g}, 0.360 \mathrm{~mol})$ dropwise at room temperature and the reaction mixture was then refluxed for 2.5 hours. The solution was cooled to room temperature, filtrated and concentrated. The residue was mixed with water $(100 \mathrm{~mL})$ and triethylamine $(100 \mathrm{ml})$, followed by stirring at room temperature for 1 hour. The resulting solution was extracted with EtOAc $(3 \times 200 \mathrm{~mL})$ and the organic phase was dried over $\mathrm{Na}_{2} \mathrm{SO}_{4}$ and concentrated. The residue was purified by flash chromatography $($ EtOAc:Hexane $=1: 9, \mathrm{v} / \mathrm{v})$ to obtain the title compound as a white solid (8.317 g, 65\%). ${ }^{1} \mathrm{H}$ NMR (300 MHz, $\left.\mathrm{CDCl}_{3}\right): \delta$ 7.30-7.34 (m, $\left.2 \mathrm{H}\right), 6.96-7.01(\mathrm{~m}, 1 \mathrm{H})$, 2.97-3.01 (m, $2 \mathrm{H}), 2.62-2.66(\mathrm{~m}, 2 \mathrm{H}) ;{ }^{13} \mathrm{C} \mathrm{NMR}\left(75.5 \mathrm{MHz}, \mathrm{CDCl}_{3}\right): \delta$ 207.2, 156.9, 143.9, 138.5, 128.7, 115.1, 114.6, 55.3, 36.0. 22.4; MS (GC-MS): 13.34 minutes, $\mathrm{m} / \mathrm{z} 162$ $\left(\mathrm{M}^{+}\right)$.

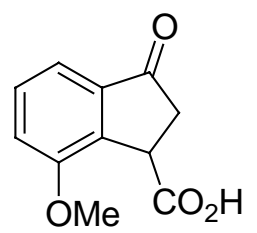

\section{7-Methoxy-3-oxo-2, 3-dihydro-1H-indene-1-carboxylic acid}

Modified literature procedure ${ }^{2}$ was used: To a solution of 4-methoxy-1-indanone $(2.000 \mathrm{~g}$, $12.33 \mathrm{mmol})$ in anhydrous $\mathrm{THF}(25 \mathrm{~mL})$ at $-78{ }^{\circ} \mathrm{C}$ was added freshly prepared LDA in THF (12.95 mmol in $65 \mathrm{~mL})$ dropwise, and the reaction mixture was stirred for 1 hour. $\operatorname{TMSCl}(1.64 \mathrm{~mL}, 12.95 \mathrm{mmol})$ was then added slowly at $-78^{\circ} \mathrm{C}$ and the reaction mixture 
was further stirred for 1 hour. The second batch of freshly prepared LDA in THF (18.50 mmol in $65 \mathrm{~mL}$ ) was added at $-78{ }^{\circ} \mathrm{C}$ and the reaction mixture was stirred for one more hour. Dry ice $(100 \mathrm{~g})$ was added and the reaction mixture was stirred at room temperature for 1.5 hours. The reaction was quenched with $2 \mathrm{M} \mathrm{HCl}$ in an ice bath and then extracted with ether $(3 \times 150 \mathrm{~mL})$. The ether phase was concentrated and the residue was redissolved in enough $2 \mathrm{M}$ aqueous $\mathrm{NaOH}$ solution until the $\mathrm{pH}$ was ca. 12. The basic aqueous solution was washed with ether $(3 \times 20 \mathrm{~mL})$ and then acidified with conc. $\mathrm{HCl}$ until the $\mathrm{pH}$ reached ca. 1. The now acidic aqueous solution was then extracted with a mixture of ether and THF $(9: 1, \mathrm{v} / \mathrm{v}, 4 \times 100 \mathrm{~mL})$. The resulting organic phase was dried over $\mathrm{Na}_{2} \mathrm{SO}_{4}$ and concentrated to give the crude product as a yellow solid (2.270 $\left.\mathrm{g}\right)$.

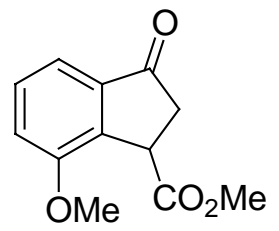

\section{Methyl 7-methoxy-3-oxo-2,3-dihydro-1H-indene-1-carboxylate 9}

To a solution of the crude carboxylic acid $(2.270 \mathrm{~g})$ in methanol $(50 \mathrm{~mL})$ was added conc. $\mathrm{H}_{2} \mathrm{SO}_{4}$ (10 drops) and the reaction mixture was refluxed for 48 hours. The solution was concentrated to ca. $5 \mathrm{~mL}$, followed by addition of saturated aqueous $\mathrm{NaHCO}_{3}$ solution to adjust the $\mathrm{pH}$ to ca. 8 . The solution was extracted with EtOAc $(3 \times 80 \mathrm{~mL})$ and the organic phase was dried over $\mathrm{Na}_{2} \mathrm{SO}_{4}$ and concentrated. The residue was purified by flash chromatograph (EtOAc:Hexane $=1: 4, \mathrm{v} / \mathrm{v})$ to obtain the ester as a yellow solid $(1.845 \mathrm{~g}$, 68\% for two steps). ${ }^{1} \mathrm{H}$ NMR (300 MHz, $\mathrm{CDCl}_{3}$ ): $\delta 7.40$ (t, $\left.7.7 \mathrm{~Hz}, 1 \mathrm{H}\right), 7.33$ (d, 8.1 Hz, $1 \mathrm{H}), 7.04$ (d, $7.8 \mathrm{~Hz}, 1 \mathrm{H}), 4.19$ (dd, $3.5 \mathrm{~Hz}, 8.2 \mathrm{~Hz}, 1 \mathrm{H}), 3.85$ (s, $3 \mathrm{H}), 3.69$ (s, $3 \mathrm{H})$, 2.95 (dd, 8.2 Hz, 11.7 Hz, 1 H), 2.73 (dd, $3.5 \mathrm{~Hz}, 11.7 \mathrm{~Hz}, 1 \mathrm{H}) ;{ }^{13} \mathrm{C}$ NMR (75.5 MHz, $\left.\mathrm{CDCl}_{3}\right): \delta 204.0,173.4,157.0,140.5,138.4,130.6,115.8,115.5,55.8,52.4,41.1,41.0$; Elemental analysis: calculated for $\mathrm{C}_{12} \mathrm{H}_{12} \mathrm{O}_{4}$ : C, 65.45, H, 5.49; found: C, 65.22, H, 5.49. 


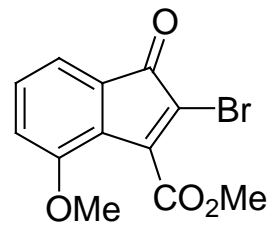

\section{Methyl 2-bromo-7-methoxy-3-oxo-3H-indene-1-carboxylate 10}

To a solution of compound 9 (2.330 g, $10.59 \mathrm{mmol})$ in freshly distilled $\mathrm{CH}_{2} \mathrm{Cl}_{2}(46 \mathrm{~mL})$ was added $\mathrm{Br}_{2}$ in $\mathrm{CH}_{2} \mathrm{Cl}_{2}(1 \mathrm{M}, 26.5 \mathrm{~mL})$ at room temperature and the solution was stirred for 24 hours. The solution was diluted with $\mathrm{CH}_{2} \mathrm{Cl}_{2}(300 \mathrm{~mL})$ and washed with water $\left(3 \times 25 \mathrm{~mL}\right.$ ). The $\mathrm{CH}_{2} \mathrm{Cl}_{2}$ phase was dried over $\mathrm{Na}_{2} \mathrm{SO}_{4}$ and concentrated. The crude product was obtained as a red solid.

To a solution of the above crude product in $\mathrm{CH}_{2} \mathrm{Cl}_{2}(100 \mathrm{~mL})$ at $0{ }^{\circ} \mathrm{C}$ was added $\mathrm{DBU}$ $(1.59 \mathrm{~mL}, 10.59 \mathrm{mmol})$ slowly and the reaction mixture was stirred at this temperature for 1 hour. The reaction solution was washed with water $(3 \times 15 \mathrm{~mL})$, dried over $\mathrm{Na}_{2} \mathrm{SO}_{4}$ and concentrated. The residue was purified by flash chromatograph (EtOAc:Hexane = 1:5, $\mathrm{v} / \mathrm{v})$ to obtain the title compound as a red solid (2.365 g, 75\% for two steps). ${ }^{1} \mathrm{H}$ NMR (300 MHz, $\left.\mathrm{CDCl}_{3}\right): \delta 7.28$ (t, $\left.4.5 \mathrm{~Hz}, 1 \mathrm{H}\right), 7.18(\mathrm{~d}, 7.2 \mathrm{~Hz}, 1 \mathrm{H}), 7.01(\mathrm{~d}, 8.4 \mathrm{~Hz}, 1 \mathrm{H})$, 3.98 (s, $3 \mathrm{H}), 3.85(\mathrm{~s}, 3 \mathrm{H}) ;{ }^{13} \mathrm{C} \mathrm{NMR}\left(75.5 \mathrm{MHz}, \mathrm{CDCl}_{3}\right): \delta 188.9,164.9,152.1,148.4$, 131.7, 129.7, 128.0, 119.6, 117.8, 116.8, 56.4, 52.9; IR (KBr): 1737, $1723 \mathrm{~cm}^{-1}$; MS

(GC-MS): 18.52 minutes, $\mathrm{m} / \mathrm{z} 296\left(\mathrm{M}^{+}\right.$containing $\left.{ }^{79} \mathrm{Br}\right) 298\left(\mathrm{M}^{+}\right.$containing $\left.{ }^{81} \mathrm{Br}\right)(1: 1)$; Elemental analysis: calculated for $\mathrm{C}_{12} \mathrm{H}_{9} \mathrm{BrO}_{4}$ : C, 48.51, H, 3.05; found: $\mathrm{C}, 48.70, \mathrm{H} 3.02$; HRMS: calculated for $\mathrm{C}_{12} \mathrm{H}_{9}{ }^{79} \mathrm{BrO}_{4}$ : 295.9684, found: 295.9689 . 


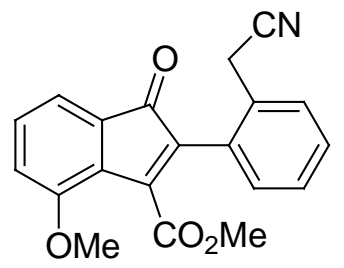

\section{Methyl 2-(2-(cyanomethyl)phenyl)-7-methoxy-3-oxo-3H-indene-1-carboxylate ${ }^{3} 11$} A mixture of compound 10 (273 mg, $0.916 \mathrm{mmol})$, KF (160 mg, $2.49 \mathrm{mmol})$, $\mathrm{Pd}_{2}(\mathrm{dba})_{3} \bullet \mathrm{CHCl}_{3}(51 \mathrm{mg}, 0.049 \mathrm{mmol})$ and $\left[(\mathrm{t}-\mathrm{Bu})_{3} \mathrm{PH}\right] \mathrm{BF}_{4}(28 \mathrm{mg}, 0.099 \mathrm{mmol})$ was deoxygenated five times with an argon balloon and a vacuum pump. Pinacolboronate (200 mg, $0.824 \mathrm{mmol}$ ) was dissolved in a mixture of THF and water $(19: 1, \mathrm{v} / \mathrm{v}, 8 \mathrm{~mL})$ and the solution was deoxygenated three times by the thaw-freeze process. The deoxygenated solution was then added to the solid mixture and stirred for 24 hours at room temperature under argon atmosphere. The solution was diluted with ether $(100 \mathrm{~mL})$ and washed with water $(3 \times 15 \mathrm{~mL})$. The organic phase was dried over $\mathrm{Na}_{2} \mathrm{SO}_{4}$ and concentrated. The residue was purified by flash chromatography $\left(\operatorname{Et}_{2} \mathrm{O}:\right.$ Hexane $\left.=1: 1, \mathrm{v} / \mathrm{v}\right)$ to obtain the product as a red orange solid (255 mg, 93\%). ${ }^{1} \mathrm{H}$ NMR (500 $\left.\mathrm{MHz}, \mathrm{CDCl}_{3}\right)$ : $\delta 7.54(\mathrm{~d}, 7.7 \mathrm{~Hz}, 1 \mathrm{H}), 7.4(\mathrm{dt}, 1.1 \mathrm{~Hz}, 7.5 \mathrm{~Hz}, 1 \mathrm{H}), 7.28(\mathrm{~m}, 2 \mathrm{H}), 7.24$ (d, $7.6 \mathrm{~Hz}, 1 \mathrm{H})$, 7.18 (d, $6.80 \mathrm{~Hz}, 1 \mathrm{H}), 7.03$ (d, $8.4 \mathrm{~Hz}, 1 \mathrm{H}), 3.85$ (s, $3 \mathrm{H}), 3.76$ (s, $3 \mathrm{H}), 3.75(\mathrm{~s}, 2 \mathrm{H})$; ${ }^{13} \mathrm{C}$ NMR $\left(125.8 \mathrm{MHz}, \mathrm{CDCl}_{3}\right): \delta 194.76,165.76,152.95,148.06,132.24,132.10$, $130.46,129.63,129.49,128.96,128.56,127.93,127.61,119.12,117.58,117.11,56.15$, 52.40, 22.49; IR (KBr): 2246, 1735, $1711 \mathrm{~cm}^{-1}$; Elemental analysis: calculated for $\mathrm{C}_{20} \mathrm{H}_{15} \mathrm{NO}_{4}$ : C, 72.06, H, 4.54; found: C, 71.88, H, 4.72; HRMS: calculated for $\mathrm{C}_{20} \mathrm{H}_{15} \mathrm{NO}_{4}$ : 333.1001 , found: 333.0985 . 


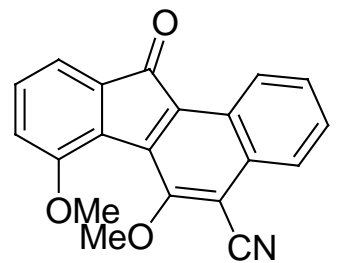

\section{6,7-Dimethoxy-11-oxo-11H-benzo[a]fluorene-5-carbonitrile 12}

To a solution of compound $\mathbf{1 1}(255 \mathrm{mg}, 0.766 \mathrm{mmol})$ in anhydrous THF $(15 \mathrm{~mL})$ at room temperature was added LDA in THF $(0.781 \mathrm{mmol}$ in $6 \mathrm{~mL})$ slowly and the solution was stirred for 1 hour. The reaction was quenched with saturated aqueous $\mathrm{NH}_{4} \mathrm{Cl}$ solution (15 $\mathrm{mL}$ ) leading to the formation of some red orange precipitate. The precipitate was dissolved in EtOAc $(600 \mathrm{~mL})$ and then washed with $\mathrm{H}_{2} \mathrm{O}(3 \times 30 \mathrm{~mL})$. The organic phase was dried over $\mathrm{Na}_{2} \mathrm{SO}_{4}$ and concentrated to obtain the crude product as a red orange solid.

To a solution of the above crude product in DMF $(100 \mathrm{~mL})$ was added $\mathrm{K}_{2} \mathrm{CO}_{3}(0.529 \mathrm{~g}$, $3.83 \mathrm{mmol}$ ) at room temperature and the mixture was stirred for 15 minutes, followed by addition of $\mathrm{CH}_{3} \mathrm{I}(0.48 \mathrm{~mL}, 7.66 \mathrm{mmol})$. The solution was heated at $80{ }^{\circ} \mathrm{C}$ for 45 minutes then filtrated and concentrated. The solution residue was diluted with $\mathrm{CHCl}_{3}(300 \mathrm{~mL})$ and washed with $\mathrm{H}_{2} \mathrm{O}(3 \times 30 \mathrm{~mL})$. The organic phase was dried over $\mathrm{Na}_{2} \mathrm{SO}_{4}$ and concentrated. The residue was purified by flash chromatograph $\left(\mathrm{CHCl}_{3}: \mathrm{Hexane}=3: 1, \mathrm{v} / \mathrm{v}\right)$ to give the product as an orange solid (140 mg, $58 \%$ for two steps). ${ }^{1} \mathrm{H}$ NMR $(300 \mathrm{MHz}$, $\mathrm{CDCl}_{3}$ ): $\delta 9.05$ (m, $\left.1 \mathrm{H}\right), 8.03(\mathrm{~m}, 1 \mathrm{H}), 7.58(\mathrm{~m}, 2 \mathrm{H}), 7.32(\mathrm{~m}, 2 \mathrm{H}), 7.15(\mathrm{~d}, 8.4 \mathrm{~Hz}, 1$ H), $4.04(\mathrm{~s}, 3 \mathrm{H}), 4.00(\mathrm{~s}, 3 \mathrm{H}) ;{ }^{13} \mathrm{C}$ NMR $\left(75.5 \mathrm{MHz}, \mathrm{CDCl}_{3}\right): \delta 194.1,157.8,154.8$, 139.2, 135.6, 135.0, 132.0, 129.2, 129.1, 127.5, 126.8, 124.7, 124.6, 120.2, 117.0, 115.1, $110.8,63.9,56.3$ (one peak missing or overlap). HRMS: calculated for $\mathrm{C}_{20} \mathrm{H}_{13} \mathrm{NO}_{3}$ : 315.0895, found: 315.0896 . 


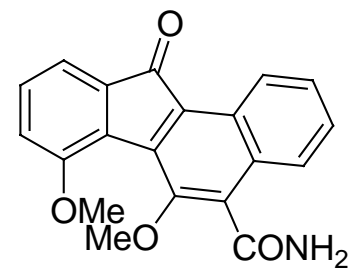

\section{6,7-Dimethoxy-11-oxo-11H-benzo[a]fluorene-5-carboxamide ${ }^{4} 13$}

To a solution of compound 12 (140 $\mathrm{mg}, 0.443 \mathrm{mmol})$ and $\mathrm{K}_{2} \mathrm{CO}_{3}(95 \mathrm{mg}, 0.687 \mathrm{mmol})$ in DMSO $(55 \mathrm{~mL})$ at $0{ }^{\circ} \mathrm{C}$ was added $30 \% \mathrm{H}_{2} \mathrm{O}_{2}(10 \mathrm{~mL})$ slowly, then the mixture was stirred at room temperature for 21 hours. The reaction was quenched with water $(60 \mathrm{~mL})$, followed by extraction with EtOAc $(300 \mathrm{~mL})$. The organic phase was washed with water ( 3 × $30 \mathrm{~mL}$ ), dried over $\mathrm{Na}_{2} \mathrm{SO}_{4}$ and concentrated. The residue was purified by flash chromatograph (EtOAc:Hexane $=3: 1, \mathrm{v} / \mathrm{v})$ to give the product as an orange solid (151 mg, 100\%). ${ }^{1} \mathrm{H}$ NMR (300 MHz, DMSO-d $\left.{ }_{6}\right): \delta 8.88(\mathrm{~d}, 8.3 \mathrm{~Hz}, 1 \mathrm{H}), 8.12(\mathrm{~s}, \mathrm{br}, 1 \mathrm{H})$, 7.88(s, br, 1 H), 7.67 (d, 8.3 Hz, 1 H), 7.52 (m, 2 H), 7.34 (m, 2 H), 7.20 (d, 6.6 Hz, 1 H), 3.93 (s, $3 \mathrm{H}), 3.75$ (s, $3 \mathrm{H}) ;{ }^{13} \mathrm{C}$ NMR (75.5 MHz, DMSO-d 6 ): $\delta$ 194.4, 168.2, 154.8, 149.2, 140.7, 138.7, 135.9, 132.4, 131.7, 129.1, 127.7, 127.6, 127.4, 127.3, 125.5, 123.7, 121.2, 116.7, 63.9, 56.5; IR ( $\mathrm{CH}_{2} \mathrm{Cl}_{2}$ film): 3389.8, 1692.6, 1654.5, 1272.1, $1046.8 \mathrm{~cm}^{-1}$; MS (EI): m/z $333.1\left(100, \mathrm{M}^{+}\right), 316.1$ (44).

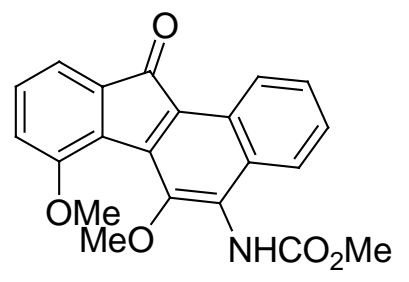

\section{Methyl 6,7-dimethoxy-11-oxo-11H-benzo[a]fluoren-5-ylcarbamate 14}

To a solution of compound $13(151 \mathrm{mg}, 0.453 \mathrm{mmol})$ in methanol $(160 \mathrm{~mL})$ was added $\mathrm{KOH}(64 \mathrm{mg}, 1.13 \mathrm{mmol})$ at room temperature. The solution was cooled to $0{ }^{\circ} \mathrm{C}$ and 
stirred for 10 minutes. $\mathrm{PhI}(\mathrm{OAc})_{2}(146 \mathrm{mg}, 0.453 \mathrm{mmol})$ was added and the mixture was stirred at $0{ }^{\circ} \mathrm{C}$ for additional 15 minutes. The solution was then warmed to room temperature and further stirred for 7 hours. The solution was concentrated and the residue was mixed with $\mathrm{CH}_{2} \mathrm{Cl}_{2}(200 \mathrm{~mL})$ and water $(100 \mathrm{~mL})$. The aqueous phase was extracted with $\mathrm{CH}_{2} \mathrm{Cl}_{2}(2 \times 100 \mathrm{~mL})$. The combined organic phase was dried over $\mathrm{Na}_{2} \mathrm{SO}_{4}$ and concentrated. The residue was purified by flash chromatography (EtOAc:Hexane = 3:1, $\mathrm{v} / \mathrm{v})$ to give the title compound as an orange solid $(115 \mathrm{mg}, 70 \%) .{ }^{1} \mathrm{H} \mathrm{NMR}(300 \mathrm{MHz}$, $\left.\mathrm{CDCl}_{3}\right): \delta 9.05(\mathrm{~d}, 8.4 \mathrm{~Hz}, 1 \mathrm{H}), 7.77(\mathrm{~d}, 8.5 \mathrm{~Hz}, 1 \mathrm{H}), 7.49(\mathrm{t}, 7.5 \mathrm{~Hz}, 1 \mathrm{H}), 7.40$ (t, 7.5 Hz, 1 H), 7.29 (m. 2 H), 7.07 (m, 1 H), 6.81 (s, br, 1 H), 3.98 (s, 3 H), 3.81 (s, 3 H), 3.80 $(\mathrm{s}, 3 \mathrm{H}) ;{ }^{13} \mathrm{C} \mathrm{NMR}\left(75.5 \mathrm{MHz}, \mathrm{CDCl}_{3}\right): \delta 194.2,155.6,154,3,147.5,139.8,136.7,133.6$, $131.3,130.8,128.6,128.3,128.0,126.6,124.4,123.9,119.5,116.8,62.6,56.3,53.1$; IR $\left(\mathrm{CH}_{2} \mathrm{Cl}_{2}\right.$ film): $3275.8,1730.0,1690.0,1283.6,1261.9,1238.0 \mathrm{~cm}^{-1} ; \mathrm{MS}(\mathrm{EI}): \mathrm{m} / \mathrm{z} 363.1$ $\left(80, \mathrm{M}^{+}\right), 331.1(100), 316.1(60), 288.1(19)$.

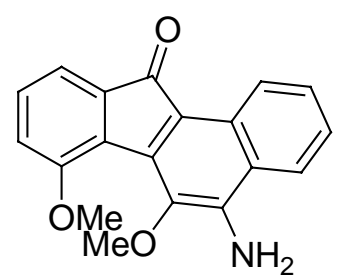

\section{5-Amino-6, 7-dimethoxy-11H-benzo[a]fluoren-11-one (15)}

To a solution of compound $14(115 \mathrm{mg}, 0.317 \mathrm{mmol})$ in ethanol $(125 \mathrm{~mL})$ was added aqueous $\mathrm{LiOH}$ solution $(2 \mathrm{M}, 0.79 \mathrm{~mL})$ slowly at room temperature and the reaction mixture was refluxed for 21 hours. The solution was concentrated and the residue was dissolved in EtOAc $(300 \mathrm{~mL})$ and washed with water $(3 \times 30 \mathrm{~mL})$. The organic phase was dried over $\mathrm{Na}_{2} \mathrm{SO}_{4}$ and concentrated. The residue was purified by flash chromatograph $($ EtOAc:Hexane $=2: 3, \mathrm{v} / \mathrm{v})$ to give the product as a red solid $(99 \mathrm{mg}, 100 \%) .{ }^{1} \mathrm{H} \mathrm{NMR}$ (300 MHz, DMSO-d $): \delta 8.85(\mathrm{~d}, 8.4 \mathrm{~Hz}, 1 \mathrm{H}), 8.12(\mathrm{~d}, 8.6 \mathrm{~Hz}, 1 \mathrm{H}), 7.44(\mathrm{t}, 7.6 \mathrm{~Hz}, 1 \mathrm{H})$, 
7.27 (m, 2 H), 7.18 (s, 1 H), 7.15 (m, 2 H), 7.06 (d, 6.9 Hz, 1 H), 3.91 (s, 3 H), 3.66 (s, 3 H); ${ }^{13} \mathrm{C}$ NMR (75.5 MHz, DMSO-d 6 ): $\delta 190.8,154.7,148.0,140.5,139.1,136.7,131.9$, $130.2,129.4,126.6,124.2,123.9,123.6,121.3,119.3,115.2,112.9,61.7,56.5$; IR ( $\mathrm{CH}_{2} \mathrm{Cl}_{2}$ film): $3315.8,3216.1,1654.0,1613.2,1546.9,1519.9,1285.9,1212.8,1097.7$, $1055.4 \mathrm{~cm}^{-1} ; \mathrm{MS}(\mathrm{EI}): \mathrm{m} / \mathrm{z} 305.1\left(100, \mathrm{M}^{+}\right), 290.1(81)$.

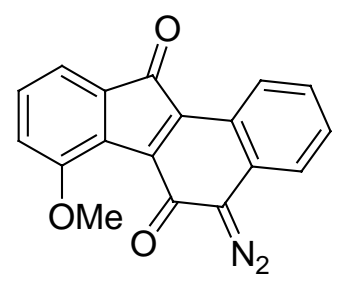

\section{5-Diazo-5H-7-methoxy-11H-benzo[a]fluoren-6, 11-dione 16}

To a solution of compound 15 (99 $\mathrm{mg}, 0.33 \mathrm{mmol})$ in ethanol $(150 \mathrm{ml})$ was added conc. $\mathrm{HCl}(2.5 \mathrm{~mL})$ at room temperature. The solution was cooled to $0{ }^{\circ} \mathrm{C}$, and an aqueous $\mathrm{NaNO}_{2}$ solution $(28 \mathrm{mg} / 0.41 \mathrm{mmol}$ in $5 \mathrm{~mL})$ was added slowly. The solution was stirred at $0{ }^{\circ} \mathrm{C}$ for 4 hours, followed by addition of $\mathrm{NaHCO}_{3}$ powder $(2.5 \mathrm{~g})$, and the mixture was stirred for additional 20 minutes. The remained $\mathrm{NaHCO}_{3}$ was filtered and the filtrate was concentrated. The residue was dissolved in EtOAc $(300 \mathrm{~mL})$ and washed with water $(3 \mathrm{x}$ $30 \mathrm{~mL}$ ). The organic phase was dried over $\mathrm{Na}_{2} \mathrm{SO}_{4}$ and concentrated. The residue was purified by flash chromatograph (EtOAc:Hexane $=1: 1, \mathrm{v} / \mathrm{v}$ ) to obtain the title compound as a purple solid (58 mg, 59\%). ${ }^{1} \mathrm{H}$ NMR $\left(500 \mathrm{MHz}, \mathrm{CD}_{2} \mathrm{Cl}_{2}\right): \delta 8.86(\mathrm{~d}, 8.1 \mathrm{~Hz}, 1 \mathrm{H})$, 7.51 (t, $7.4 \mathrm{~Hz}, 1 \mathrm{H}), 7.40$ (d, $8.0 \mathrm{~Hz}, 1 \mathrm{H}), 7.33$ (m, 2 H), 7.25 (d, $6.7 \mathrm{~Hz}, 1 \mathrm{H}), 7.13$ (d, $8.1 \mathrm{~Hz}, 1 \mathrm{H}), 3.96(\mathrm{~s}, 3 \mathrm{H}) ;{ }^{13} \mathrm{C} \mathrm{NMR}\left(125.8 \mathrm{MHz}, \mathrm{CD}_{2} \mathrm{Cl}_{2}\right) *: \delta 196.2,170.5,154.8,133.7$, 133.6, 131.4, 129.4, 128.6, 127.5, 126.5, 125.7, 122.2, 121.2, 119.5, 117.0, 56.5 (missing two peaks); IR ( $\mathrm{CH}_{2} \mathrm{Cl}_{2}$ solution): 3061.0, 2945.0, 2838.1, 2095.7, 1710.8, 1620.1, 1480.1 $1336.0 \mathrm{~cm}^{-1}$; MS (EI): m/z $302.1\left(30, \mathrm{M}^{+}\right), 274.1$ (96), 259.1 (100), 231.1 (25), 187.1 (24), 175.1 (23); HRMS (EI): calculated for $\mathrm{C}_{18} \mathrm{H}_{10} \mathrm{O}_{3} \mathrm{~N}_{2}: 302.0691$, found: 302.0691 . 
*As a result of low solubility of the title compound in $\mathrm{CD}_{2} \mathrm{Cl}_{2}$, no ${ }^{13} \mathrm{C}$ NMR signal was observed for the quaternary carbon attached to the diazo group. A cross peak at $90.0 \mathrm{ppm}$, assignable to the carbon atom attached to the diazo group, is a clear evidence, however, in the HMBC experiment.

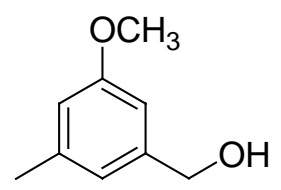

\section{(3-methoxy-5-methylphenyl)methanol ${ }^{6}$}

To a solution of 3,5-dimethylanisole $(4.752 \mathrm{~g}, 34.90 \mathrm{mmol})$ in HOAc $(50 \mathrm{~mL})$ were added $N$-hydroxyphthalimide $(0.569 \mathrm{~g}, 3.490 \mathrm{mmol})$ and $\mathrm{Co}(\mathrm{OAc})_{2} \bullet 4 \mathrm{H}_{2} \mathrm{O}(0.174 \mathrm{~g}, 0.698$ mmol). The solution was stirred at $100{ }^{\circ} \mathrm{C}$ for 72 hours. The solution was concentrated, and $1 \mathrm{M}$ aqueous $\mathrm{NaOH}$ solution was added to the residue to adjust the $\mathrm{pH}$ to ca. 12. The resulting solution was extracted with $\mathrm{CH}_{2} \mathrm{Cl}_{2}(3 \times 100 \mathrm{~mL})$, and the organic phase was dried over $\mathrm{Na}_{2} \mathrm{SO}_{4}$ and concentrated. The residue was purified by flash chromatography $($ EtOAc:Hexane $=1: 20, \mathrm{v} / \mathrm{v})$ to recover the starting material 3,5-dimethylanisole $(1.712 \mathrm{~g}$, $36 \%$ ) and meanwhile to obtain the crude aldehyde. The $\mathrm{pH}$ of the basic aqueous phase was adjusted to ca. 1 by adding conc. $\mathrm{HCl}$ and the resulting solution was extracted with EtOAc $(100 \mathrm{~mL} \times 4)$. The EtOAc Phase was dried over $\mathrm{Na}_{2} \mathrm{SO}_{4}$ and concentrated to obtain the crude carboxylic acid. The crude aldehyde and carboxylic acid were combined $(3.425 \mathrm{~g})$ and subjected to the next reduction step.

To a mixture of $\mathrm{LiAlH}_{4}(1.299 \mathrm{~g}, 34.25 \mathrm{mmol})$ suspended in anhydrous THF $(75 \mathrm{~mL})$ at $0{ }^{\circ} \mathrm{C}$ was added slowly the anhydrous THF solution of the above crude products $(3.425 \mathrm{~g}$ in $9 \mathrm{~mL}$ ), and the reaction mixture was further stirred at $0{ }^{\circ} \mathrm{C}$ for 15 minutes. The solution was then warmed to room temperature and stirred for 20 hours. Saturated aqueous $\mathrm{NH}_{4} \mathrm{Cl}$ solution was added at $0{ }^{\circ} \mathrm{C}$ to quench the excess $\mathrm{LiAlH}_{4}$ until no more gas bubbles were 
generated, followed by filtration. The filtrate was dried over $\mathrm{Na}_{2} \mathrm{SO}_{4}$ and concentrated. The residue was purified by flash chromatograph (EtOAc:Hexane $=1: 5, \mathrm{v} / \mathrm{v})$ to obtain the title compound as a white solid (1.487 g, 28\% for two steps). ${ }^{1} \mathrm{H}$ NMR (300 MHz, $\left.\mathrm{CDCl}_{3}\right): \delta 6.71(\mathrm{~s}, 1 \mathrm{H}), 6.68(\mathrm{~s}, 1 \mathrm{H}), 6.62(\mathrm{~s}, 1 \mathrm{H}), 4.53(\mathrm{~s}, 2 \mathrm{H}), 3.74(\mathrm{~s}, 3 \mathrm{H}), 3.08(\mathrm{~s}, 1$ H), $2.30(\mathrm{~s}, 3 \mathrm{H}) ;{ }^{13} \mathrm{C}$ NMR $\left(75.5 \mathrm{MHz}, \mathrm{CDCl}_{3}\right): \delta$ 159.7, 142.4, 139.5, 120.0, 113.9, 109.2, 64.9, 55.1, 21.4; IR ( $\mathrm{CH}_{2} \mathrm{Cl}_{2}$ film): 3366.1, 2999.8, 2940.0, 2871.3, 2839.1, 1613.5, 1462.7, 1325.3, 1295.3, 1193.6, 1152.5, $1068.2 \mathrm{~cm}^{-1}$; MS (EI): m/z $152.09\left(100, \mathrm{M}^{+}\right)$, 137.07 (23), 123.09 (39), 109.07 (22), 91.05 (18), 77.02 (11).

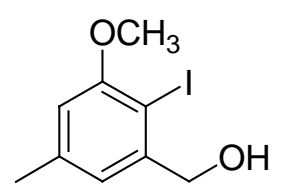

\section{(2-iodo-3-methoxy-5-methylphenyl)ethanol (17)}

To a solution of compound $16(3.743 \mathrm{~g}, 24.62 \mathrm{mmol})$ in anhydrous diethyl ether $(160 \mathrm{~mL})$ was added $n$-BuLi in hexane (1.6 M, $33.86 \mathrm{~mL})$ slowly, and the solution was warmed to room temperature and stirred for 4 hours, after which the solution was cooled to $0{ }^{\circ} \mathrm{C}$ again. Anhydrous THF $(80 \mathrm{ml})$ was then added to the solution and the reaction mixture was stirred for 1 hour, followed by slow addition of $\mathrm{I}_{2}(7.687 \mathrm{~g}, 30.29 \mathrm{mmol})$ dissolved in minimum amount of THF and the mixture was further stirred for 30 minutes at $0{ }^{\circ} \mathrm{C}$. The reaction mixture was washed with $10 \%$ aqueous $\mathrm{Na}_{2} \mathrm{~S}_{2} \mathrm{O}_{3}$ solution and then mixed with saturated aqueous $\mathrm{NH}_{4} \mathrm{Cl}$ solution $(50 \mathrm{~mL})$, followed by extraction with $\mathrm{Et}_{2} \mathrm{O}(100 \mathrm{~mL} \times$ 3). The organic phase was dried over $\mathrm{Na}_{2} \mathrm{SO}_{4}$ and concentrated. The residue was purified by flash chromatograph (EtOAc:Hexane = 1:5, v/v) to obtain the title compound as a white solid (5.068 g, 74\%). ${ }^{1} \mathrm{H}$ NMR (300 MHz, $\left.\mathrm{CDCl}_{3}\right): \delta 6.86(\mathrm{~s}, 1 \mathrm{H}), 6.54(\mathrm{~s}, 1 \mathrm{H})$, $4.59(\mathrm{~s}, 2 \mathrm{H}), 3.83(\mathrm{~s}, 3 \mathrm{H}), 2.60(\mathrm{~s}, 1 \mathrm{H}), 2.30(\mathrm{~s}, 3 \mathrm{H}) ;{ }^{13} \mathrm{C} \mathrm{NMR}\left(75.5 \mathrm{MHz}, \mathrm{CDCl}_{3}\right): \delta$ 157.7, 144.0, 139.7, 121.7, 111.1, 85.2, 69.4, 56.5, 21.4; IR $\left(\mathrm{CH}_{2} \mathrm{Cl}_{2}\right.$ film): 3262.1, 2902.6, 1651.8, 1575.5, 1457.7, 1433.9, 1409.8, 1356.2, 1307.6, 1168.2, 1099.7, 1041.8, 
1009.6, 839.7, 582.0 $\mathrm{cm}^{-1}$; MS (EI): m/z $278.0\left(100, \mathrm{M}^{+}\right), 263.0(5)$.

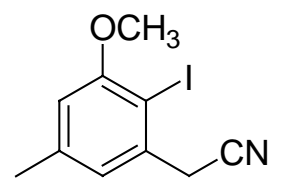

\section{2-(2-iodo-3-methoxy-5-methylphenyl)acetonitrile (18)}

To a solution of compound $17(5.068 \mathrm{~g}, 18.23 \mathrm{mmol})$ in anhydrous $\mathrm{CH}_{2} \mathrm{Cl}_{2}(100 \mathrm{~mL})$ was added $\mathrm{CBr}_{4}(6.348 \mathrm{~g}, 19.14 \mathrm{mmol})$ at room temperature. The solution was cooled to $0{ }^{\circ} \mathrm{C}$ and $\mathrm{PPh}_{3}(5.021 \mathrm{~g}, 19.14 \mathrm{mmol})$ was added slowly. The solution was then warmed to room temperature and stirred for 6 hours. The solution was concentrated and the residue was purified by flash chromatograph (EtOAc:Hexane $=1: 50, \mathrm{v} / \mathrm{v}$ ) to obtain the title compound as a white solid.

To a solution of the above white solid in anhydrous DMSO $(30 \mathrm{~mL})$ was added $\mathrm{NaCN}$ $(1.340 \mathrm{~g}, 27.35 \mathrm{mmol})$ and the mixture was stirred for 36 hours. The reaction mixture was diluted with water $(150 \mathrm{ml})$ and extracted with $\mathrm{CH}_{2} \mathrm{Cl}_{2}(2 \times 100 \mathrm{~mL})$. The organic phase was dried over $\mathrm{Na}_{2} \mathrm{SO}_{4}$ and concentrated. The residue was purified by flash chromatograph $($ EtOAc:Hexane $=1: 20, \mathrm{v} / \mathrm{v})$ to obtain the title compound as a white solid (3.606 g, 69\% for two steps). ${ }^{1} \mathrm{H}$ NMR $\left(300 \mathrm{MHz} \mathrm{CDCl}_{3}\right): \delta 6.91(\mathrm{~s}, 1 \mathrm{H}), 6.55(\mathrm{~s}, 1 \mathrm{H})$, $3.82(\mathrm{~s}, 3 \mathrm{H}), 3.73(\mathrm{~s}, 2 \mathrm{H}), 2.30(\mathrm{~s}, 3 \mathrm{H}) ;{ }^{13} \mathrm{C} \mathrm{NMR}\left(75.5 \mathrm{MHz}, \mathrm{CDCl}_{3}\right): \delta 158.4,140.3$, 134.5, 122.2, 117.6, 111.4, 87.4, 56.6, 30.2, 21.4; IR $\left(\mathrm{CH}_{2} \mathrm{Cl}_{2}\right.$ film): 3020.3, 2968.7, 2942.4, 2920.1, 2250.9, 1572.7, 1458.9, 1408.0, 1391.9, 1319.7, 1298.3, 1243.0, 1184.4, 1081.5, $1015.7 \mathrm{~cm}^{-1}$; MS (EI): m/z $287.0\left(100, \mathrm{M}^{+}\right), 272.0$ (9); HRMS (EI): calculated for $\mathrm{C}_{10} \mathrm{H}_{10} \mathrm{ONI}: 286.9807$, found: 286.9816. 


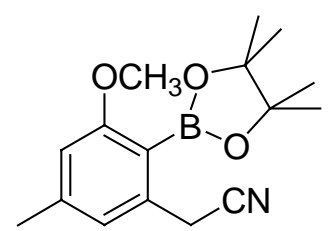

\section{2-(3-methoxy-5-methyl-2-(4,4,5,5-tetramethyl-1,3,2-dioxaborolan-2-yl)phenyl) acetonitrile $^{7}(19)$}

To a solution of compound $18(1.500 \mathrm{~g}, 5.226 \mathrm{mmol})$ in anhydrous dioxane $(18 \mathrm{~mL})$ were added pinacolborane $(2.28 \mathrm{~mL}, 15.98 \mathrm{mmol})$ and $\mathrm{Et}_{3} \mathrm{~N}(2.91 \mathrm{~mL}, 20.91 \mathrm{mmol})$, and the mixture was degassed three times by the thaw-freeze process. $\mathrm{Pd}(\mathrm{OAc})_{2}(59 \mathrm{mg}, 0.2613$ mmol) and (2-biphenyl)dicyclohexyl-phosphine $(366 \mathrm{mg}, 1.045 \mathrm{mmol})$ were added to the mixture then the reaction mixture was degassed again by the thaw-freeze process. The mixture was stirred at $100{ }^{\circ} \mathrm{C}$ for 4 hours. Saturated aqueous $\mathrm{NH}_{4} \mathrm{Cl}$ solution $(20 \mathrm{~mL})$ was added to the solution at $0{ }^{\circ} \mathrm{C}$ followed by extraction with $\mathrm{CH}_{2} \mathrm{Cl}_{2}(2 \times 100 \mathrm{~mL})$. The organic phase was dried over $\mathrm{Na}_{2} \mathrm{SO}_{4}$ and concentrated, and the residue was purified by flash chromatograph $($ EtOAc:Hexane $=1: 10, \mathrm{v} / \mathrm{v})$ to obtain the title compound as a white solid (1.229 g, 82\%). ${ }^{1} \mathrm{H}$ NMR (300 MHz, $\left.\mathrm{CDCl}_{3}\right): \delta 6.77$ (s, $\left.1 \mathrm{H}\right), 6.56(\mathrm{~s}, 1 \mathrm{H}), 3.76$ (s, $2 \mathrm{H}), 3.71(\mathrm{~s}, 3 \mathrm{H}), 2.28(\mathrm{~s}, 3 \mathrm{H}), 1.31(\mathrm{~s}, 12 \mathrm{H}) ;{ }^{13} \mathrm{C} \mathrm{NMR}\left(75.5 \mathrm{MHz}, \mathrm{CDCl}_{3}\right): \delta 164.2$, 142.3, 135.7, 121.6, 118.5, 110.8, 83.8, 55.8, 24.7, 23.4, 21.7; IR ( $\mathrm{CH}_{2} \mathrm{Cl}_{2}$ film): 3458.1, 2978.7, 2935.6, 2838.5, 2249.0, 1612.1, 1567.3, 1144.2, 1084.9, $1063.8 \mathrm{~cm}^{-1}$; MS (EI): m/z $287.2\left(100, \mathrm{M}^{+}\right), 286.2$ (27), 272.2 (26), 228.2 (38), 214.2 (25), 200.2 (37), 187.1 (99), 186.1 (32), 161.1 (18), 131.1 (26), 130.1 (12); HRMS (EI): calculated for $\mathrm{C}_{16} \mathrm{H}_{22} \mathrm{O}_{3} \mathrm{~N}^{10} \mathrm{~B}: 286.1729$, found: 286.1722 . 


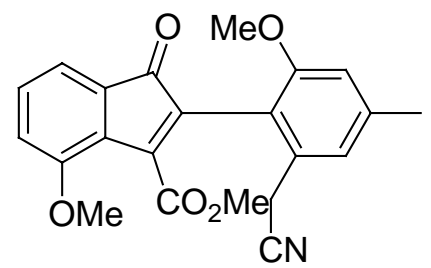

\section{Methyl 2-(2-(cyanomethyl)-6-methoxy-4-methylphenyl)-7-methoxy-3-oxo-3H-indene -1-carboxylate (20)}

Compound 10 (132 mg, $0.443 \mathrm{mmol}$ ) was mixed with KF (77 mg, $1.329 \mathrm{mmol})$, $\mathrm{Pd}_{2}(\mathrm{dba})_{3} \cdot \mathrm{CHCl}_{3}(23 \mathrm{mg}, 0.022 \mathrm{mmol})$ and $\left[(t-\mathrm{Bu})_{3} \mathrm{PH}\right] \mathrm{BF}_{4}(13 \mathrm{mg}, 0.044 \mathrm{mmol})$ and the mixture was deoxygenated five times with an argon balloon and vacuum pump. Compound 19 (114 mg, $0.339 \mathrm{mmol})$ was dissolved in a mixture of THF and water (19:1, $\mathrm{v} / \mathrm{v}, 4 \mathrm{~mL}$ ) and the solution was deoxygenated three times using the thaw-freeze process. The deoxygenated solution was then added to the mixture of solids and the reaction mixture was stirred at room temperature for 24 hours under argon atmosphere. The solution was then diluted with $\mathrm{Et}_{2} \mathrm{O}(100 \mathrm{~mL})$ and washed with $\mathrm{H}_{2} \mathrm{O}(3 \times 10 \mathrm{~mL})$. The aqueous phase was extracted with $\mathrm{Et}_{2} \mathrm{O}(2 \times 50 \mathrm{~mL})$ and all $\mathrm{Et}_{2} \mathrm{O}$ phases were combined. The organic phase was dried over $\mathrm{Na}_{2} \mathrm{SO}_{4}$ and concentrated. The residue was purified by flash chromatograph (EtOAc:Hexane $=1: 3, \mathrm{v} / \mathrm{v}$ ) to obtain the title compound as an orange solid (127 mg, 85\%). ${ }^{1} \mathrm{H}$ NMR (300 MHz, $\left.\mathrm{CDCl}_{3}\right): \delta 7.27$ (m, $\left.1 \mathrm{H}\right), 7.16(\mathrm{~d}, 6.8$ $\mathrm{Hz}, 1 \mathrm{H}), 7.01$ (d, $8.3 \mathrm{~Hz}, 1 \mathrm{H}), 6.93(\mathrm{~s}, 1 \mathrm{H}), 6.67$ (s, $1 \mathrm{H}), 3.83$ (s, $3 \mathrm{H}), 3.75(\mathrm{~s}, 3 \mathrm{H})$, 3.73 (d, 19.0 Hz, 1 H), 3.69 (s, $3 \mathrm{H}), 3.64$ (d, $19.0 \mathrm{~Hz}, 1 \mathrm{H}), 2.35$ (s, $3 \mathrm{H}) ;{ }^{13} \mathrm{C}$ NMR (75.5 $\left.\mathrm{MHz}, \mathrm{CDCl}_{3}\right): \delta 195.1,166.0,158.1,152.8,148.3,141.0,131.8,131.1,130.8,130.4$, $128.0,121.2,119.0,118.0,117.0,115.1,111.4,56.2,55.8,52.4,22.0,21.8 ; \mathrm{IR}\left(\mathrm{CH}_{2} \mathrm{Cl}_{2}\right.$ film): 2950.0, 2842.3, 2251.6, 1733.1, 1717.1, 1610.0, 1575.8, 1479.4, 1464.0, 1337.9, 1274.2, 1242.6, 1202.1, 1173.8, 1092.5, $1055.1 \mathrm{~cm}^{-1}$; MS (EI): m/z $377.2\left(100, \mathrm{M}^{+}\right)$, 345.1 (25), 318.1 (40), 286.1 (65), 59.2 (12); HRMS (EI): calculated for $\mathrm{C}_{22} \mathrm{H}_{19} \mathrm{NO}_{5}$ : 377.1263, found: 377.1263 . 


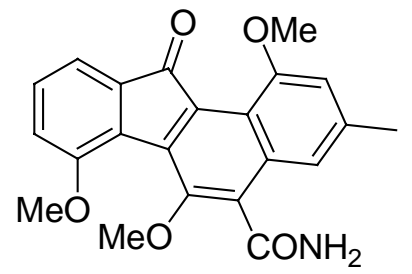

\section{1, 6, 7-trimethoxy-3-methyl-11-oxo-11H-benzo[a]fluorene-5-carboxamide (27)}

Preparation of lithium complex solution ${ }^{8}$ : To a solution of $i-\mathrm{Bu}_{2} \mathrm{AlH}(1.75 \mathrm{~mL}, 1.75$ mmol) in anhydrous THF $(2.05 \mathrm{~mL})$ at $-78{ }^{\circ} \mathrm{C}$ was added $n$-BuLi in hexane $(1.20 \mathrm{~mL}$, $1.75 \mathrm{mmol}$ ) slowly, the mixture was further stirred for 1 hour.

Preparation of LDA: To a solution of $i-\mathrm{Pr}_{2} \mathrm{NH}(0.26 \mathrm{~mL}, 1.834 \mathrm{mmol})$ in anhydrous THF $(8.54 \mathrm{~mL})$ at $0{ }^{\circ} \mathrm{C}$ was added $n$-BuLi in hexane $(1.20 \mathrm{~mL}, 1.75 \mathrm{mmol})$ slowly, and the mixture was further stirred for 30 minutes.

To a solution of compound $20(66 \mathrm{mg}, 0.175 \mathrm{mmol})$ in anhydrous THF $(4 \mathrm{~mL})$ at $-78{ }^{\circ} \mathrm{C}$ was added the above lithium complex solution $(0.5 \mathrm{~mL})$ slowly, and the reaction mixture was further stirred for 1 hour, followed by slow addition of the freshly prepared LDA solution $(1.25 \mathrm{~mL})$. The solution was stirred for 1 hour at $-78{ }^{\circ} \mathrm{C}$ and then warmed to room temperature to be further stirred for 5 hours. Saturated aqueous $\mathrm{NH}_{4} \mathrm{Cl}$ solution (10 $\mathrm{mL}$ ) was added to quench the reaction and the mixture was stirred for 20 minutes at $0{ }^{\circ} \mathrm{C}$. The resulting solution was extracted with $\mathrm{CH}_{2} \mathrm{Cl}_{2}(3 \times 50 \mathrm{~mL})$. The organic phase was dried over $\mathrm{Na}_{2} \mathrm{SO}_{4}$ and concentrated to obtain the crude product as a red orange solid (75 $\mathrm{mg})$.

To a solution of the above crude product $(75 \mathrm{mg})$ in anhydrous DMF $(10 \mathrm{~mL})$ was added $\mathrm{K}_{2} \mathrm{CO}_{3}(121 \mathrm{mg})$ and the reaction mixture was stirred at room temperature for 10 minutes, followed by addition of $\mathrm{CH}_{3} \mathrm{I}(0.11 \mathrm{~mL})$. The reaction mixture was heated and stirred at 
$80{ }^{\circ} \mathrm{C}$ for 45 minutes. The solution was cooled to room temperature and diluted with $\mathrm{H}_{2} \mathrm{O}$ $(100 \mathrm{~mL})$, followed by extraction with $\mathrm{Et}_{2} \mathrm{O}(3 \times 100 \mathrm{~mL})$. The organic phase was washed with $\mathrm{H}_{2} \mathrm{O}(3 \times 30 \mathrm{~mL})$, dried over $\mathrm{Na}_{2} \mathrm{SO}_{4}$ and concentrated to obtain the crude product as a red orange solid $(63 \mathrm{mg})$.

To a solution of the above crude product $(63 \mathrm{mg})$ and $\mathrm{K}_{2} \mathrm{CO}_{3}(37 \mathrm{mg})$ in DMSO $(25 \mathrm{ml})$ at $0{ }^{\circ} \mathrm{C}$ was added slowly $30 \% \mathrm{H}_{2} \mathrm{O}_{2}(5 \mathrm{~mL})$. The solution was warmed to room temperature and stirred for 24 hours. The reaction mixture was diluted with $\mathrm{H}_{2} \mathrm{O}(100 \mathrm{~mL})$ and then extracted with EtOAc $(3 \times 100 \mathrm{~mL})$. The EtOAc phase was washed with $\mathrm{H}_{2} \mathrm{O}$ $(30 \mathrm{~mL} \times 3)$, dried over $\mathrm{Na}_{2} \mathrm{SO}_{4}$ and concentrated. The residue was purified by flash

chromatograph (EtOAc:Hexane = 2:1, v/v) to obtain the title compound as a red orange solid (34 mg, 51\% for three steps). ${ }^{1} \mathrm{H}$ NMR (300 MHz, DMSO-d $\left.\mathrm{d}_{6}\right): \delta 8.04(\mathrm{~s}, 1 \mathrm{H}), 7.78$ (s, $1 \mathrm{H}), 7.35(\mathrm{~m}, 1 \mathrm{H}), 7.26(\mathrm{~d}, 8.2 \mathrm{~Hz}, 1 \mathrm{H}), 7.15$ (d, $6.8 \mathrm{~Hz}, 1 \mathrm{H}), 7.00$ (s, $1 \mathrm{H}), 6.83$ (s, $1 \mathrm{H}), 3.91(\mathrm{~s}, 3 \mathrm{H}), 3.87(\mathrm{~s}, 3 \mathrm{H}), 3.70(\mathrm{~s}, 3 \mathrm{H}), 2.38(\mathrm{~s}, 3 \mathrm{H}) ;{ }^{13} \mathrm{C}$ NMR $(75.5 \mathrm{MHz}$, DMSO-d 6 ): $\delta 190.4,168.5,156.2,154.4,149.5,140.1,138.0,137.3,135.8,133.6,131.8$, 131.6, 126.9, 120.2, 118.4, 116.5, 116.4, 110.1, 63.5, 56.1, 55.6, 22.2; IR $\left(\mathrm{CH}_{2} \mathrm{Cl}_{2}\right.$ film): $3425.0,3337.5,2937.5,2837.5,1706.3,1670.9,1605.8,1554.6,1483.8,1355.5,1266.3$, $1047.6 \mathrm{~cm}^{-1}$; MS (EI): m/z $377.2\left(100, \mathrm{M}^{+}\right)$; HRMS (EI): Calc for $\mathrm{C}_{22} \mathrm{H}_{19} \mathrm{O}_{5} \mathrm{~N}: 377.1263$, found: 377.1268 .

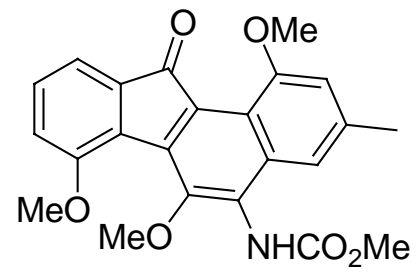

Methyl 1, 6, 7-trimethoxy-3-methyl-11-oxo-11H-benzo[a]fluoren-5-ylcarbamate (28) To a solution of compound $27(24 \mathrm{mg}, 0.065 \mathrm{mmol})$ and $\mathrm{KOH}(9 \mathrm{mg}, 0.16 \mathrm{mmol})$ in 
anhydrous methanol $(14 \mathrm{~mL})$ at $0{ }^{\circ} \mathrm{C}$ was added $\mathrm{PhI}(\mathrm{OAc})_{2}(21 \mathrm{mg}, 0.065 \mathrm{mmol})$. The reaction mixture was stirred for 30 minutes at $0{ }^{\circ} \mathrm{C}$, then warmed to room temperature and stirred for 3 hours. The solution was diluted with EtOAc $(150 \mathrm{~mL})$ and washed with brine $(3 \times 15 \mathrm{~mL})$. The organic phase was dried over $\mathrm{Na}_{2} \mathrm{SO}_{4}$ and concentrated. The residue was purified by flash chromatograph (EtOAc:Hexane $=1: 1, \mathrm{v} / \mathrm{v}$ ) to obtain the title compound as a red orange solid (26 mg, 99\%). ${ }^{1} \mathrm{H} \mathrm{NMR}\left(300 \mathrm{MHz}, \mathrm{CD}_{2} \mathrm{Cl}_{2}\right): \delta 7.24$ (m, $2 \mathrm{H}), 7.12(\mathrm{~s}, 1 \mathrm{H}), 7.06(\mathrm{~d}, 7.9 \mathrm{~Hz}, 1 \mathrm{H}), 6.82(\mathrm{~s}, 1 \mathrm{H}), 6.66(\mathrm{~s}, 1 \mathrm{H}), 3.94(\mathrm{~s}, 6 \mathrm{H})$, $3.78(\mathrm{~s}, 3 \mathrm{H}), 3.73(\mathrm{~s}, 3 \mathrm{H}), 2.37(\mathrm{~s}, 3 \mathrm{H}) ;{ }^{13} \mathrm{C}$ NMR $\left(75.5 \mathrm{MHz}, \mathrm{CD}_{2} \mathrm{Cl}_{2}\right): \delta 190.3,156.3$, 155.6, 153.9, 149.0, 139.8, 137.6, 136.4, 133.7, 132.1, 130.7, 130.5, 127. 3, 118.9, 118.6, 116.1, 114.8, 109.6, 61.8, 56.0, 55.6, 52.7, 21.8; IR $\left(\mathrm{CH}_{2} \mathrm{Cl}_{2}\right.$ film): 3304.4, 2939.3, 1706.2, 1605.5, 1559.8, 1483.9, 1273.5, $1045.8 \mathrm{~cm}^{-1}$; MS (EI): $407.1\left(100, \mathrm{M}^{+}\right), 375.1$ (15); HRMS (EI): calculated for $\mathrm{C}_{23} \mathrm{H}_{21} \mathrm{O}_{6} \mathrm{~N}$ : 407.1369, found: 407.1377.

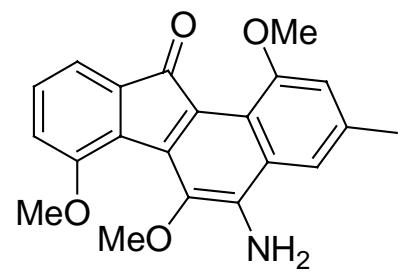

\section{5-amino-1,6,7-trimethoxy-3-methyl-11H-benzo[a]fluoren-11-one (29)}

To a solution of compound $28(26 \mathrm{mg}, 0.065 \mathrm{mmol})$ in ethanol $(16 \mathrm{~mL})$ was added aqueous $\mathrm{LiOH}$ solution $(4 \mathrm{M}, 0.16 \mathrm{~mL}, 0.65 \mathrm{mmol}$ ) and the mixture was refluxed for 24 hours. The solution was concentrated to ca. $5 \mathrm{~mL}$ and then diluted with $\mathrm{CH}_{2} \mathrm{Cl}_{2}(100 \mathrm{~mL})$. The resulting solution was washed with $\mathrm{H}_{2} \mathrm{O}(3 \times 10 \mathrm{~mL})$, and the aqueous phase was extracted with $\mathrm{CH}_{2} \mathrm{Cl}_{2}(2 \times 50 \mathrm{~mL})$. The combined $\mathrm{CH}_{2} \mathrm{Cl}_{2}$ phase was dried over $\mathrm{Na}_{2} \mathrm{SO}_{4}$ and concentrated. The residue was purified by flash chromatograph (EtOAc:Hexane = 1:1, $\mathrm{v} / \mathrm{v}$ ) to obtain the title compound as a dark red solid (23 mg, 100\%). ${ }^{1} \mathrm{H}$ NMR (300 MHz, DMSO-d $)): \delta 7.46(\mathrm{~s}, 1 \mathrm{H}), 7.26(\mathrm{~m}, 1 \mathrm{H}), 7.13(\mathrm{~d}, 8.3 \mathrm{~Hz}, 1 \mathrm{H}), 7.02(\mathrm{~d}, 6.9 \mathrm{~Hz}, 1 \mathrm{H})$, 
6.75 (m, br, 3 H), 3.88 (s, $3 \mathrm{H}), 3.82$ (s, $3 \mathrm{H}), 3.62$ (s, $3 \mathrm{H}), 2.36$ (s, $3 \mathrm{H}) ;{ }^{13} \mathrm{C}$ NMR $(75.5$ MHz, DMSO-d $\left.{ }_{6}\right): \delta$ 187.5, 156.6, 154.2, 146.1, 140.8, 138.9, 136.8, 134.6, 131.3, 126.6, 123.8, 120.7, 118.7, 115.9, 115.1, 114.6, 110.7, 61.1, 56.6, 55.8, 22.0; $\mathrm{IR}\left(\mathrm{CH}_{2} \mathrm{Cl}_{2}\right.$ film): 3394.6, 1627.8, 1513.1, 1457.0, $1269.9 \mathrm{~cm}^{-1}$; MS (EI): m/z $349.1\left(100, \mathrm{M}^{+}\right), 334.1$ (27), 319.1 (18); HRMS (EI): calculated for $\mathrm{C}_{21} \mathrm{H}_{19} \mathrm{O}_{4} \mathrm{~N}$ : 349.1314 , found: 349.1323.

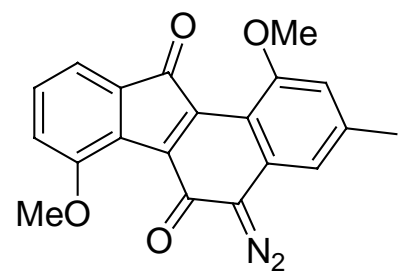

\section{Dimethylisoprekinamycin (30)}

To a solution of compound $29(15 \mathrm{mg}, 0.044 \mathrm{mmol})$ in ethanol and water $(5: 1, \mathrm{v} / \mathrm{v}, 12 \mathrm{~mL})$ at $0{ }^{\circ} \mathrm{C}$ was added dilute $\mathrm{HCl}(1.2 \mathrm{M}, 0.91 \mathrm{~mL})$ slowly and the mixture was stirred for 10 minutes. An aqueous solution of $\mathrm{NaNO}_{2}(4 \mathrm{mg} / 0.044 \mathrm{mmol}$ in $0.5 \mathrm{~mL})$ was added and the reaction was stirred at $0{ }^{\circ} \mathrm{C}$ for 1 hour, followed by addition of aqueous $\mathrm{NaHCO}_{3}$ solution $\left(150 \mathrm{mg}\right.$ in $2.0 \mathrm{~mL}$ ), and the mixture was stirred at $0{ }^{\circ} \mathrm{C}$ for additional 20 minutes. The reaction mixture was diluted with EtOAc $(150 \mathrm{~mL})$ and washed with $\mathrm{H}_{2} \mathrm{O}(3 \times 20 \mathrm{~mL})$. The organic phase was dried over $\mathrm{Na}_{2} \mathrm{SO}_{4}$ and concentrated. The residue was purified by flash chromatograph (EtOAc:Hexane $=1: 2, \mathrm{v} / \mathrm{v}$ ) to obtain the title compound as a dark purple solid (10 mg, 63\%). ${ }^{1} \mathrm{H}$ NMR (500 MHz, $\left.\mathrm{CD}_{2} \mathrm{Cl}_{2}\right): \delta 7.33(\mathrm{~m}, 1 \mathrm{H}), 7.27(\mathrm{~d}, 6.5$ Hz, 1 H), 7.16 (d, 8.2 Hz, 1 H), 6.86 (s, 1 H), 6.69 (s, 1 H), 3.99 (s, 3 H), 3.98 (s, 3 H), $2.48(\mathrm{~s}, 3 \mathrm{H}) ;{ }^{13} \mathrm{C}$ NMR $\left(125.8 \mathrm{MHz}, \mathrm{CD}_{2} \mathrm{Cl}_{2}\right) *: \delta$ 192.2, 171.2, 158.3, 154.4, 142.1, $140.9,139.2,133.9,130.9,130.4,127.4,120.5,116.7,112.5,110.7,109.1,56.7,55.8$, 21.7; IR ( $\mathrm{CH}_{2} \mathrm{Cl}_{2}$ solution): 2996.6, 2926.9, 2852.8, 2112.6, 1722.3, 1608.6, 1563.4, 1483.9, 1468.0, $1361.4 \mathrm{~cm}^{-1}$; MS (EI): m/z $346.1\left(78, \mathrm{M}^{+}\right), 318.1$ (100), 303.1 (97), 275.1 (27), 247.1 (22), 219.1 (15), 189.1 (23), 187.1 (12); HRMS (EI): calculated for 
$\mathrm{C}_{20} \mathrm{H}_{14} \mathrm{O}_{4} \mathrm{~N}_{2}: 346.0954$, found: 346.0953 .

*As the result of low solubility of the title compound in $\mathrm{CD}_{2} \mathrm{Cl}_{2}$, no ${ }^{13} \mathrm{C}$ NMR signal was observed for the quaternary carbon attached to the diazo group. A cross peak at $88.0 \mathrm{ppm}$, assignable to the carbon atom attached diazo group, is a clear evidence, however, in the HMBC experiment.

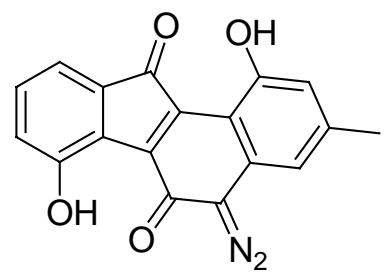

\section{Isoprekinamycin 4}

To a solution of compound $\mathbf{3 0}(8 \mathrm{mg}, 0.022 \mathrm{mmol})$ in anhydrous $\mathrm{CH}_{2} \mathrm{Cl}_{2}(2 \mathrm{~mL})$ at $-78{ }^{\circ} \mathrm{C}$ was added slowly a $\mathrm{CH}_{2} \mathrm{Cl}_{2}$ solution of $\mathrm{BCl}_{3}(1 \mathrm{M}, 0.09 \mathrm{~mL}, 0.09 \mathrm{mmol})$, and the reaction mixture was stirred for 30 minutes. The reaction mixture was warmed to room temperature and further stirred for 90 minutes, followed by addition of ice $(1 \mathrm{~g})$ and $\mathrm{CH}_{2} \mathrm{Cl}_{2}(100 \mathrm{~mL})$. The $\mathrm{CH}_{2} \mathrm{Cl}_{2}$ solution was washed with water $(3 \times 10 \mathrm{~mL})$, dried over $\mathrm{Na}_{2} \mathrm{SO}_{4}$ and concentrated. The residue was purified by flash chromatograph $\left(\mathrm{Et}_{2} \mathrm{O}: \mathrm{CH}_{2} \mathrm{Cl}_{2}=1: 200, \mathrm{v} / \mathrm{v}\right)$ to obtain the title compound as a dark purple solid (5 mg, 64\%). $\mathrm{H}^{1} \mathrm{NMR}\left(500 \mathrm{MHz}, \mathrm{CD}_{2} \mathrm{Cl}_{2}\right): \delta$ 12.32(s, $\left.1 \mathrm{H}\right), 11.61(\mathrm{~s}, 1 \mathrm{H}), 7.26(\mathrm{~d}, 6.7 \mathrm{~Hz}, 1 \mathrm{H})$, $7.18(\mathrm{t}, 7.6 \mathrm{~Hz}, 1 \mathrm{H}), 7.06$ (d, $8.3 \mathrm{~Hz}, 1 \mathrm{H}), 6.72(\mathrm{~s}, 1 \mathrm{H}), 6.69$ (s, $1 \mathrm{H}), 2.41$ (s, $1 \mathrm{H})$; IR $\left(\mathrm{CH}_{2} \mathrm{Cl}_{2}\right.$ solution): 3686.1, 3600.7, 2926.6, 2855.0, 2126.1, 1733.9, 1686.8, 1611.5, 1560.5, $1466.5 \mathrm{~cm}^{-1}$; UV-vis (HPLC): 211.0, 247.4, 284.0, $561.3 \mathrm{~nm}$. 


\section{c) ${ }^{1} \mathrm{H}$ and ${ }^{13} \mathrm{C}$ NMR spectra}

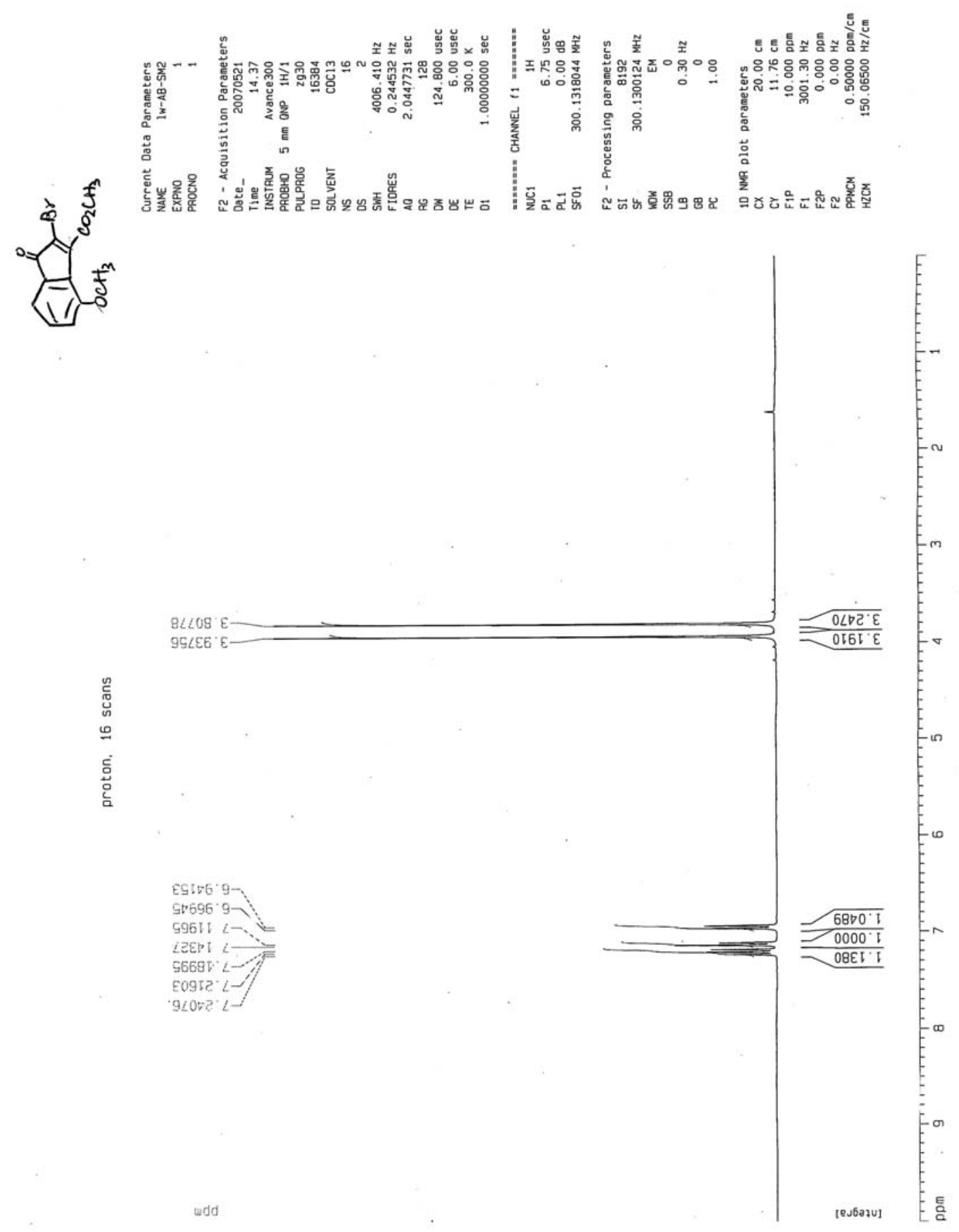



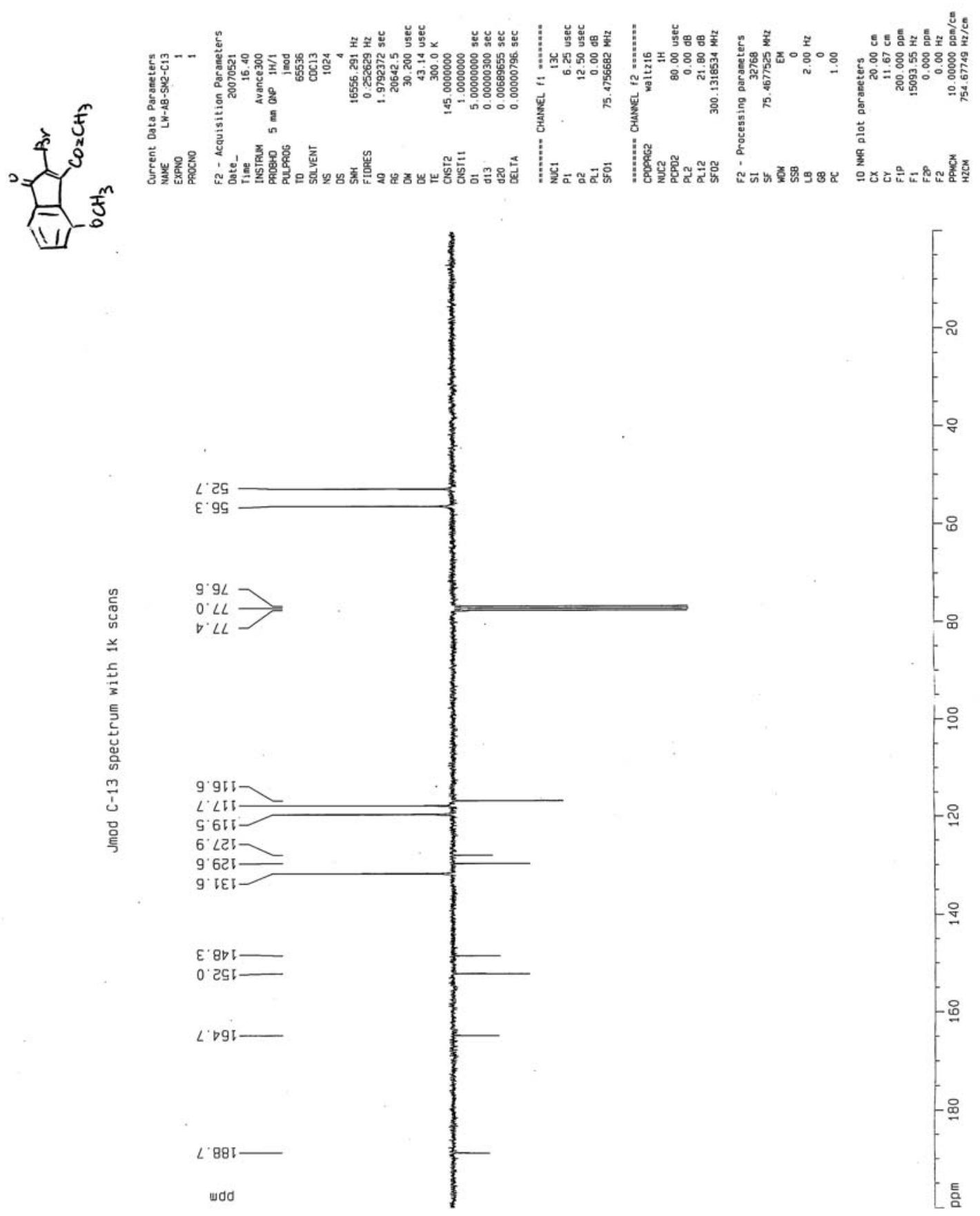

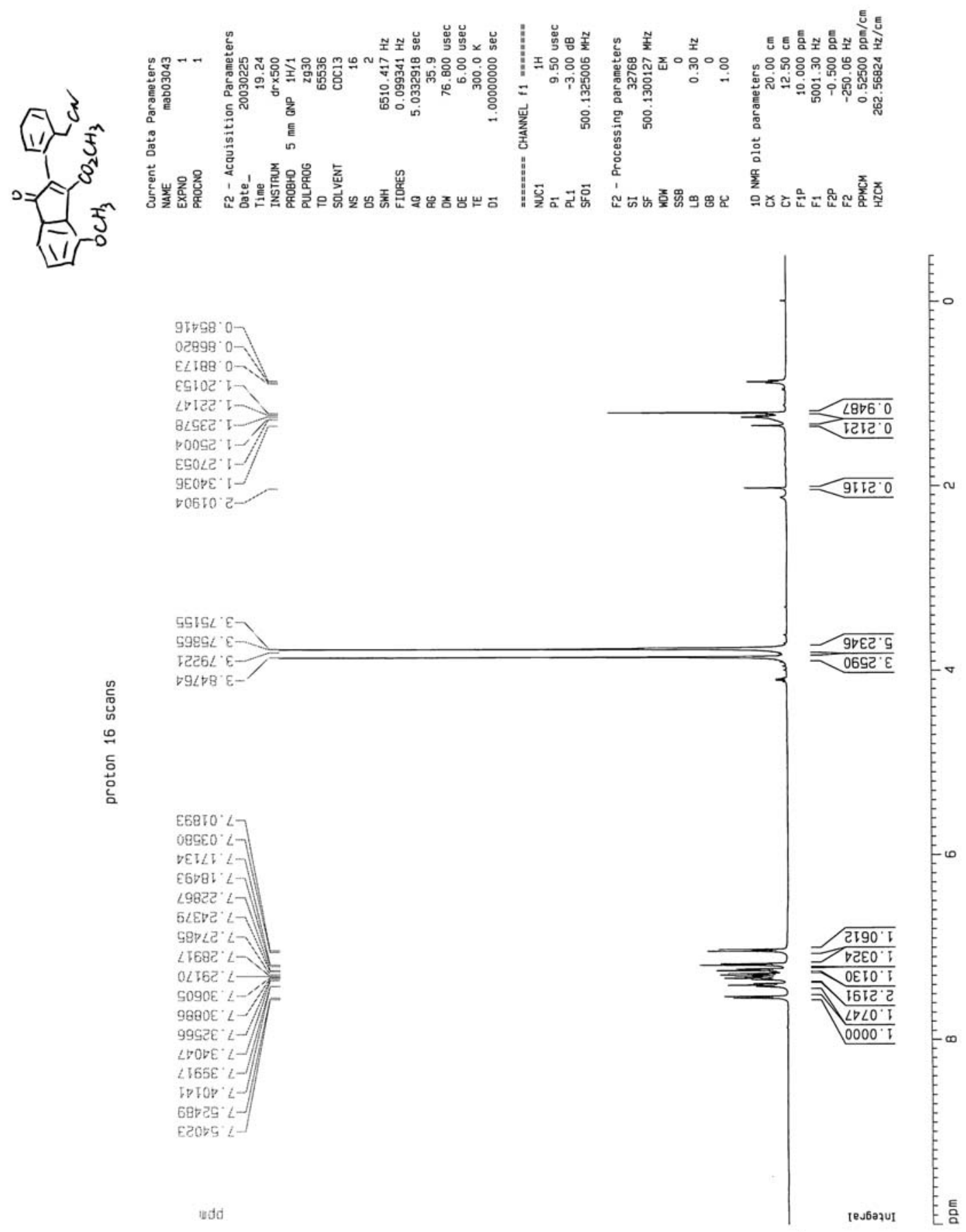

udd

SSISL $E$

$5989 t \cdot \varepsilon-$

$\checkmark 9 \angle \nabla B E-$

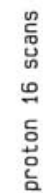

E6810 $\angle$

$08560^{\circ}[7$

EITL

$\angle 982 C^{\prime}:$

6tEv己' $t-$

$58 \nabla 2 e^{\circ} L=$

toge 2

SO90E :

$98800^{\circ}<-/ \mid$

S9GZE $L-$

$\checkmark O V E^{\circ} L-$

$\angle$ I65E $~ i-$

Iplop ' $L$

68025 L $L$

E20:5 2$]$ 

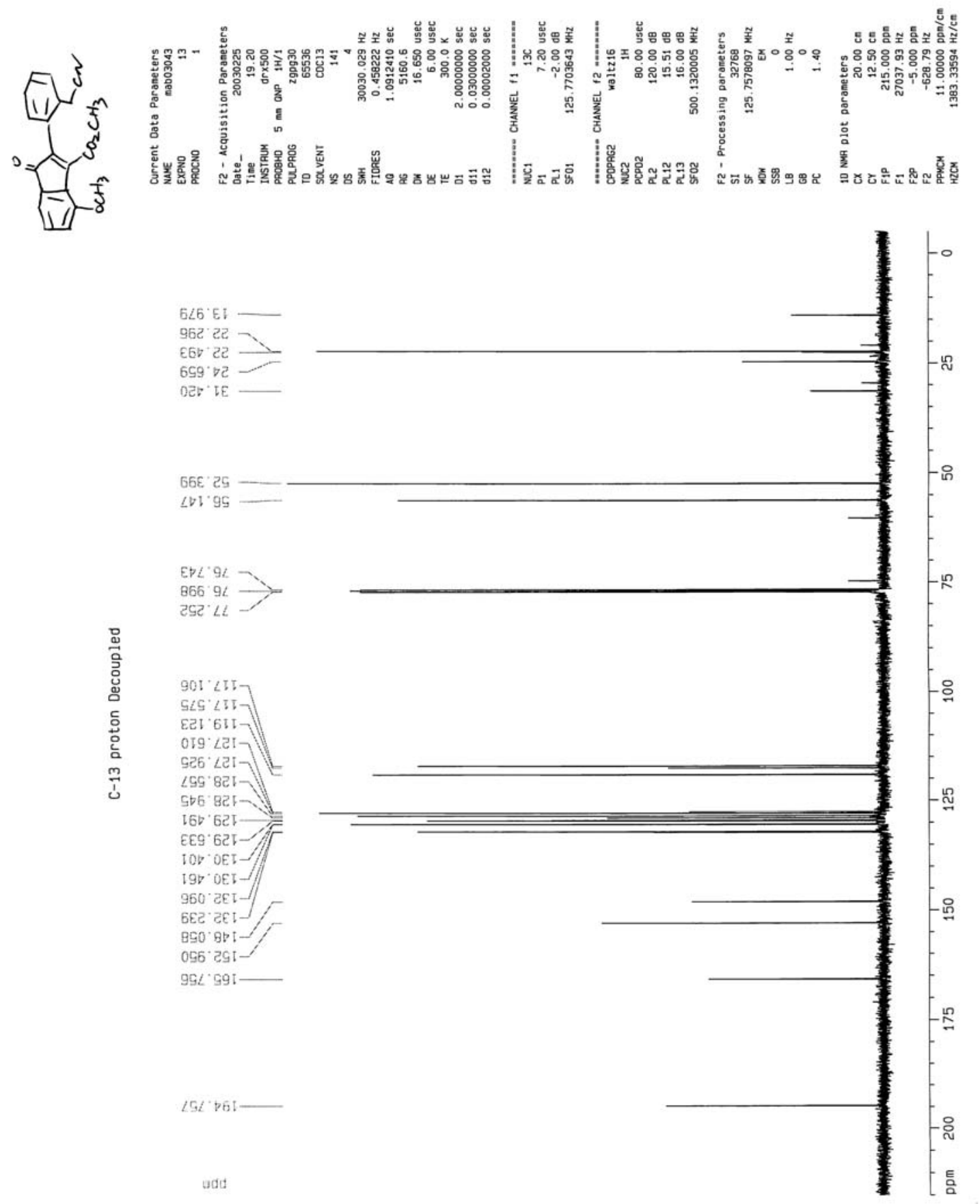

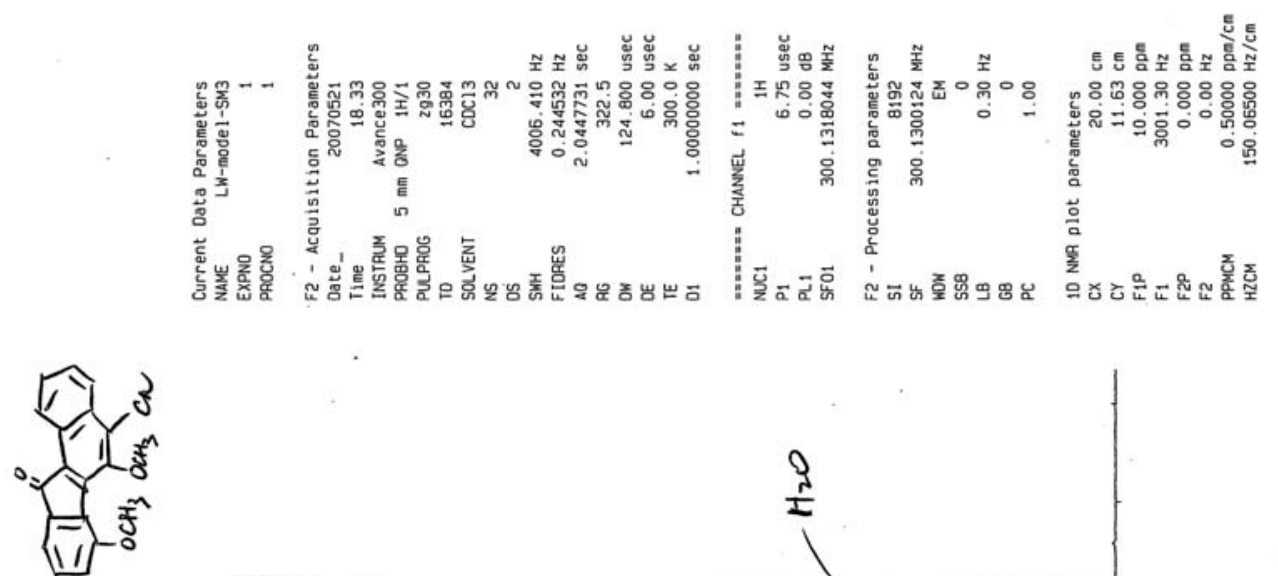

GSEES:
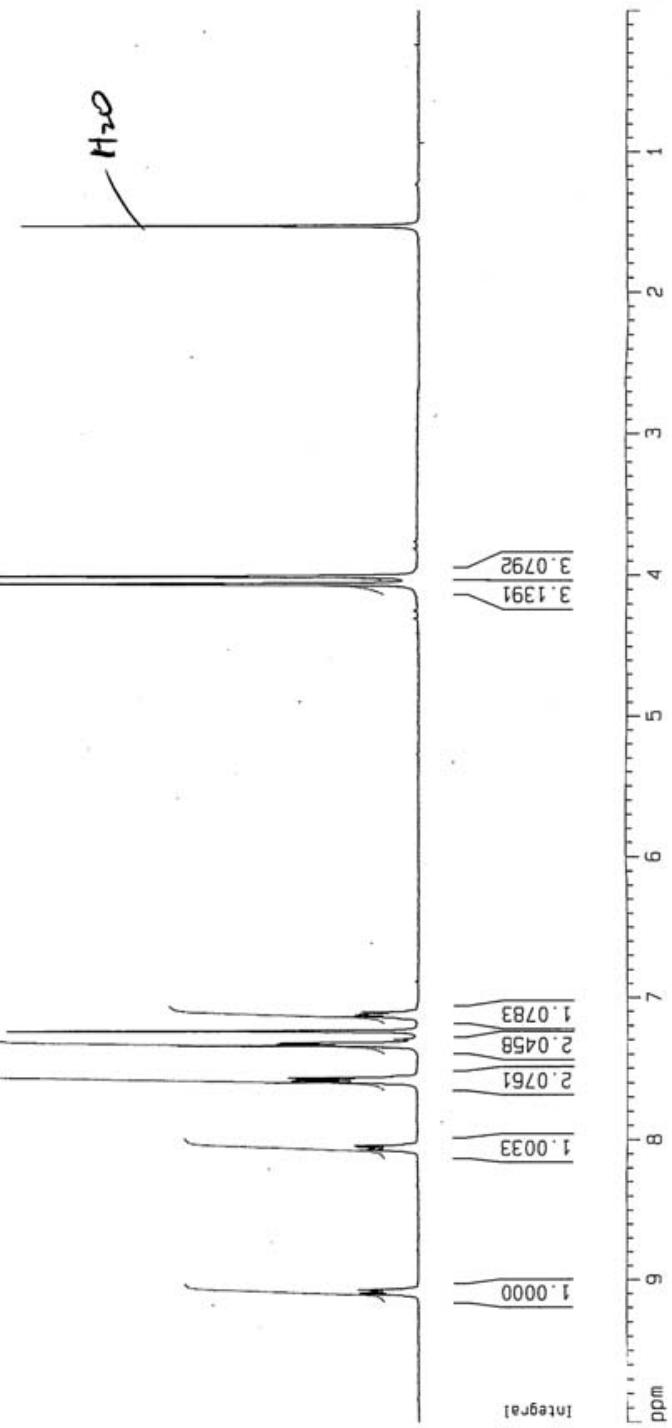

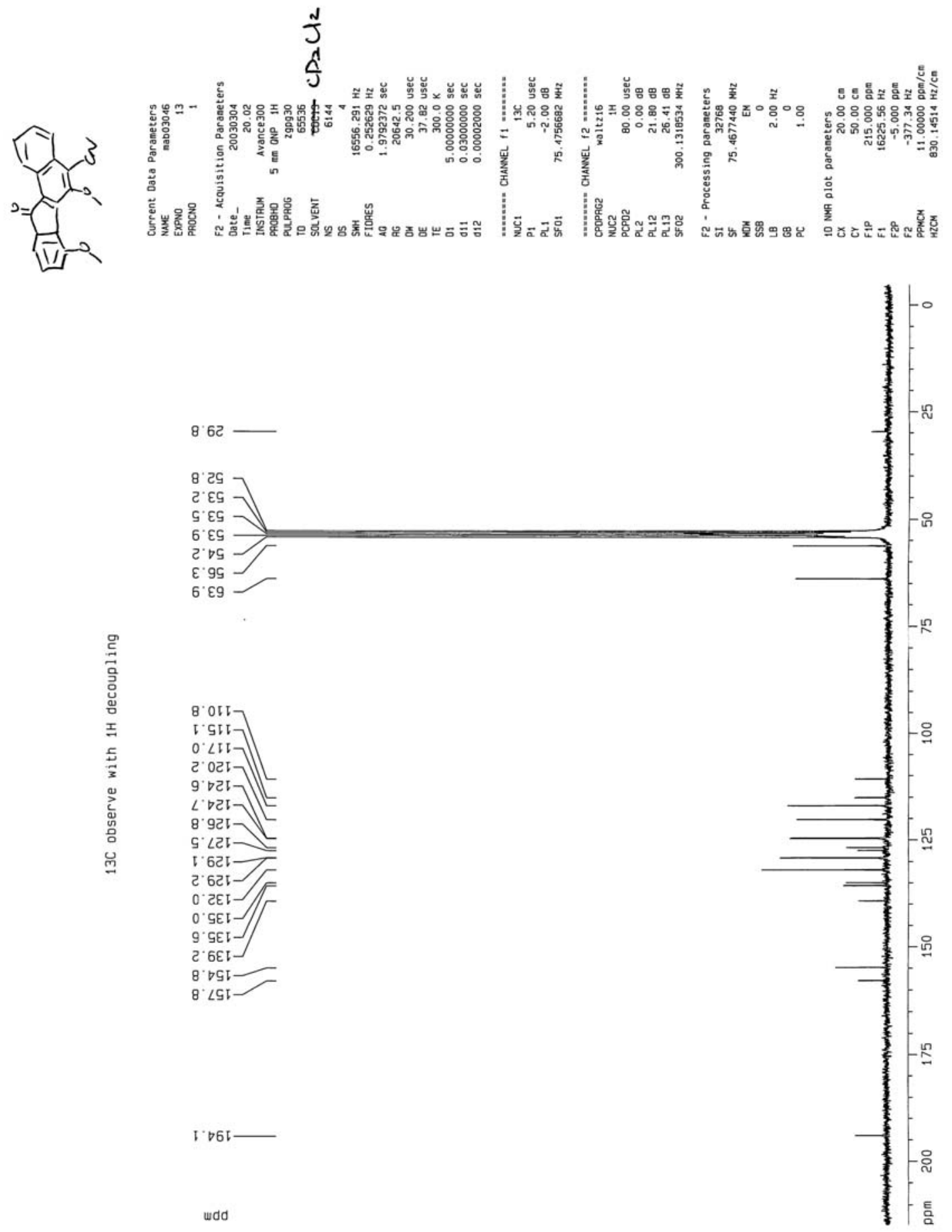


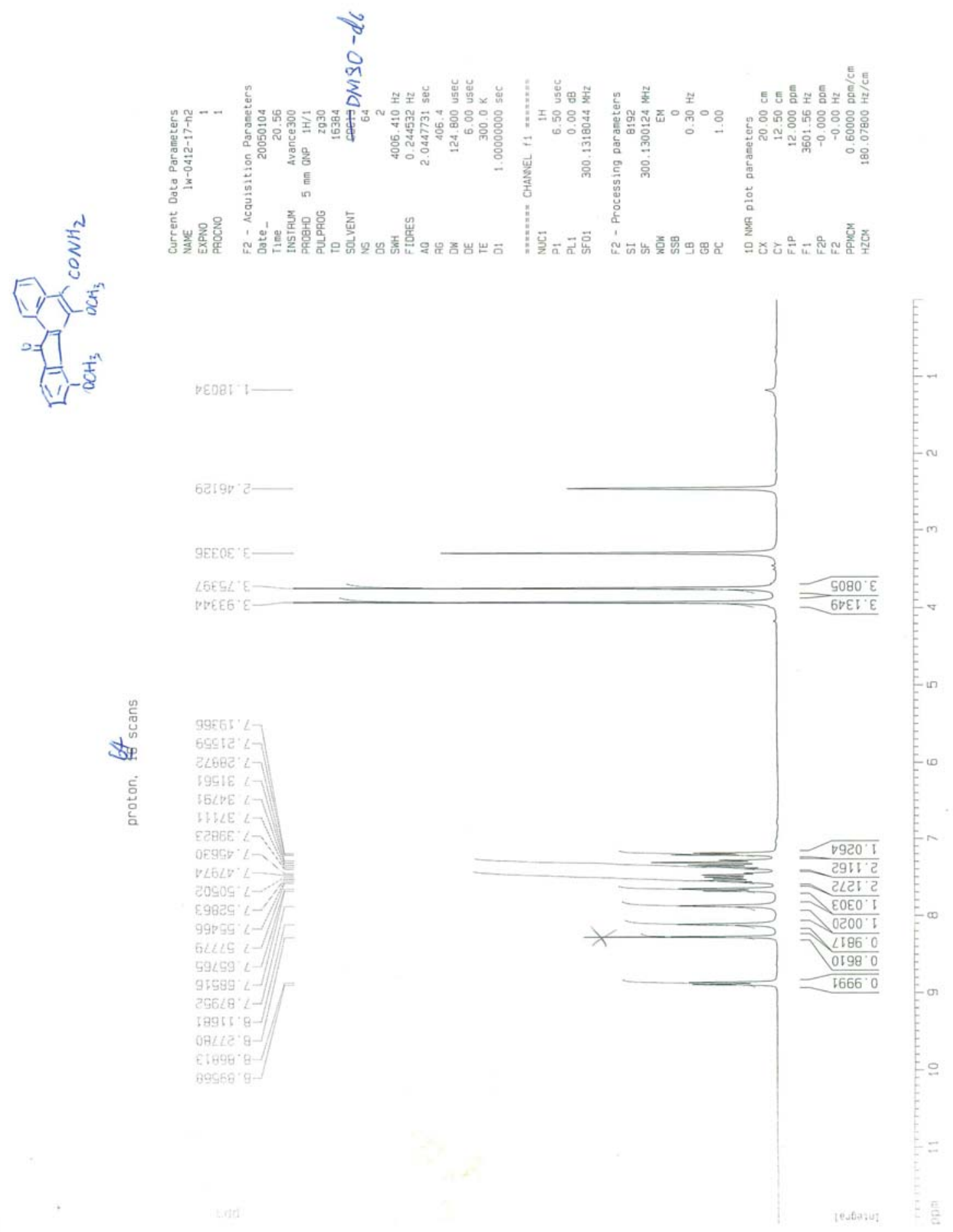




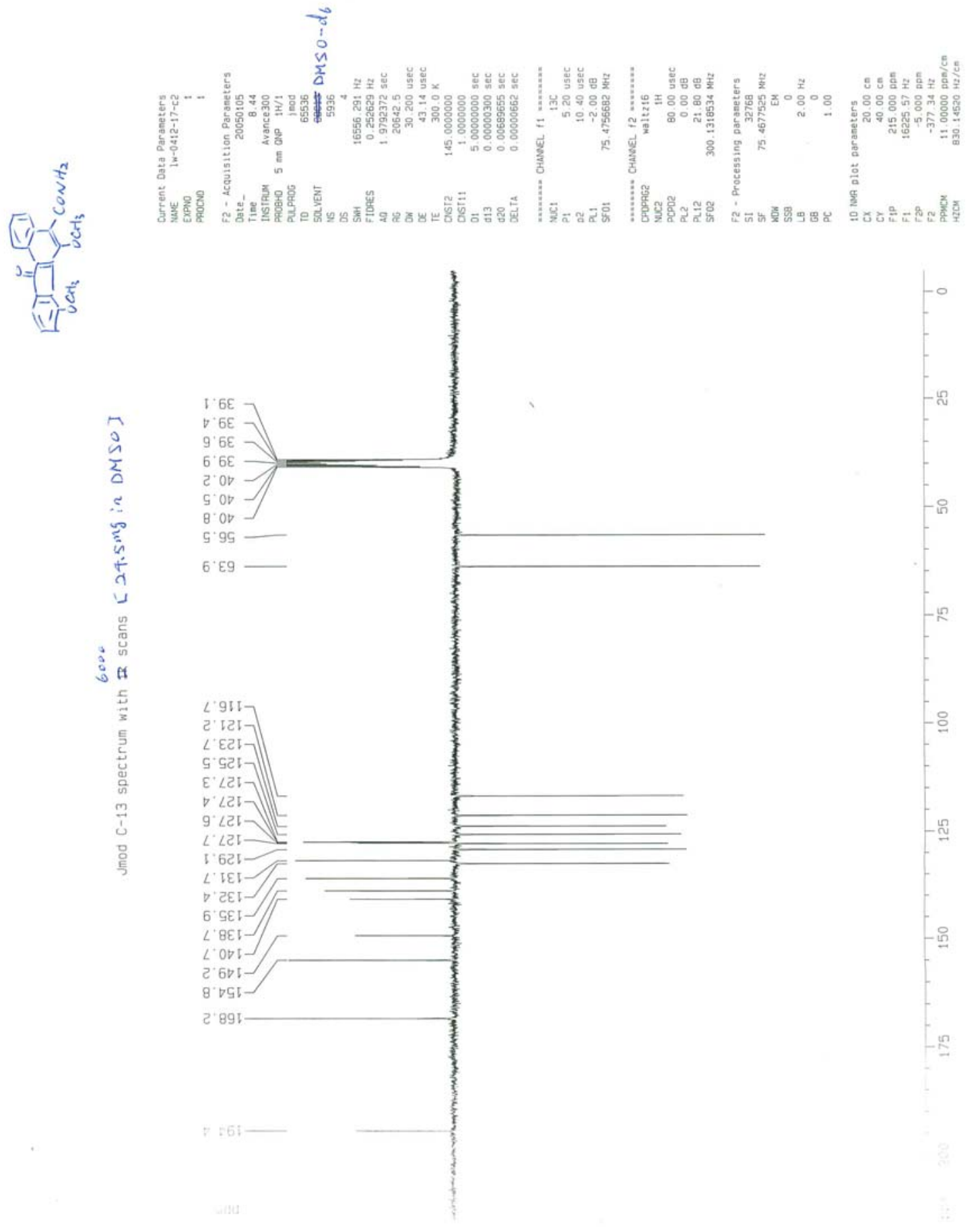




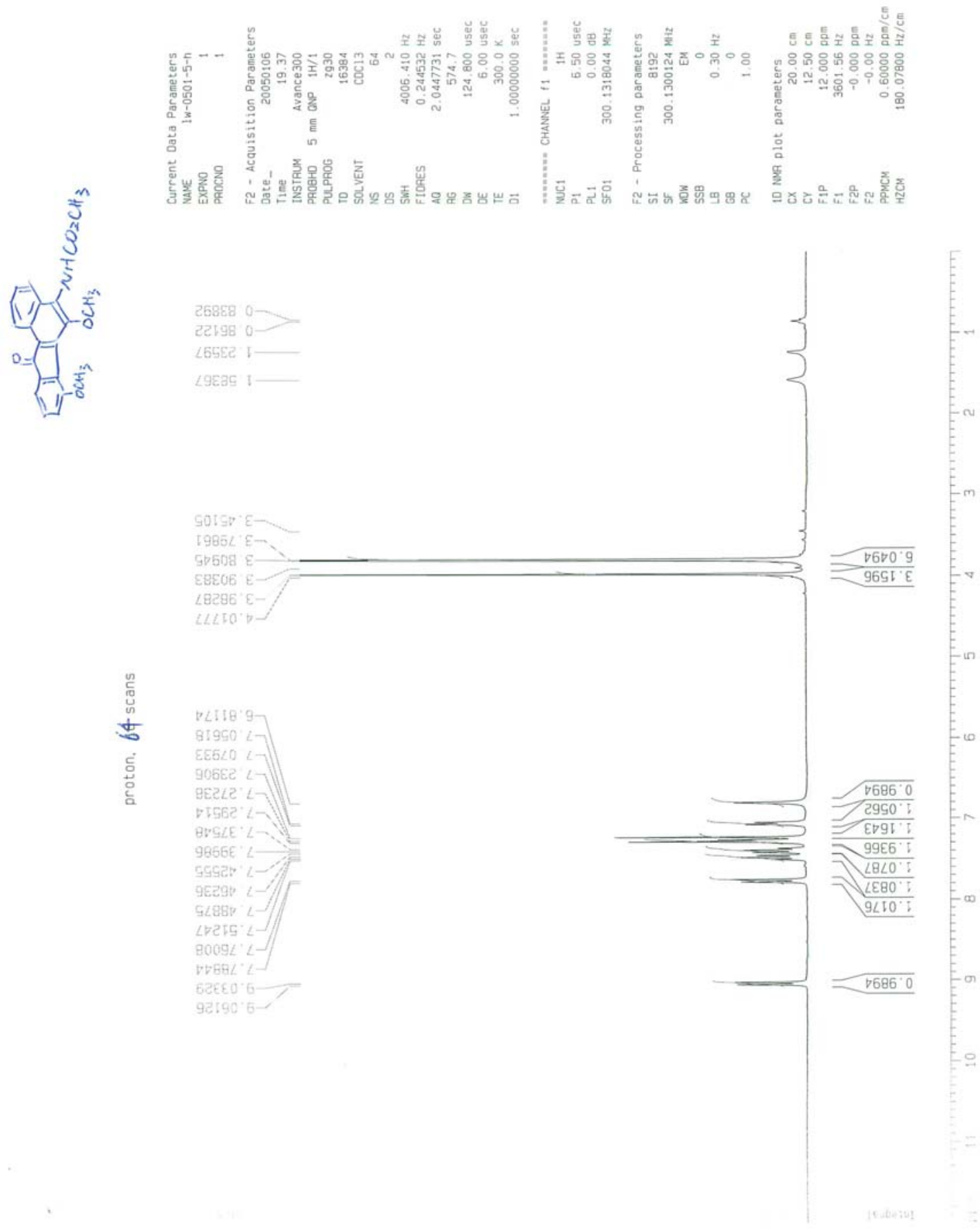



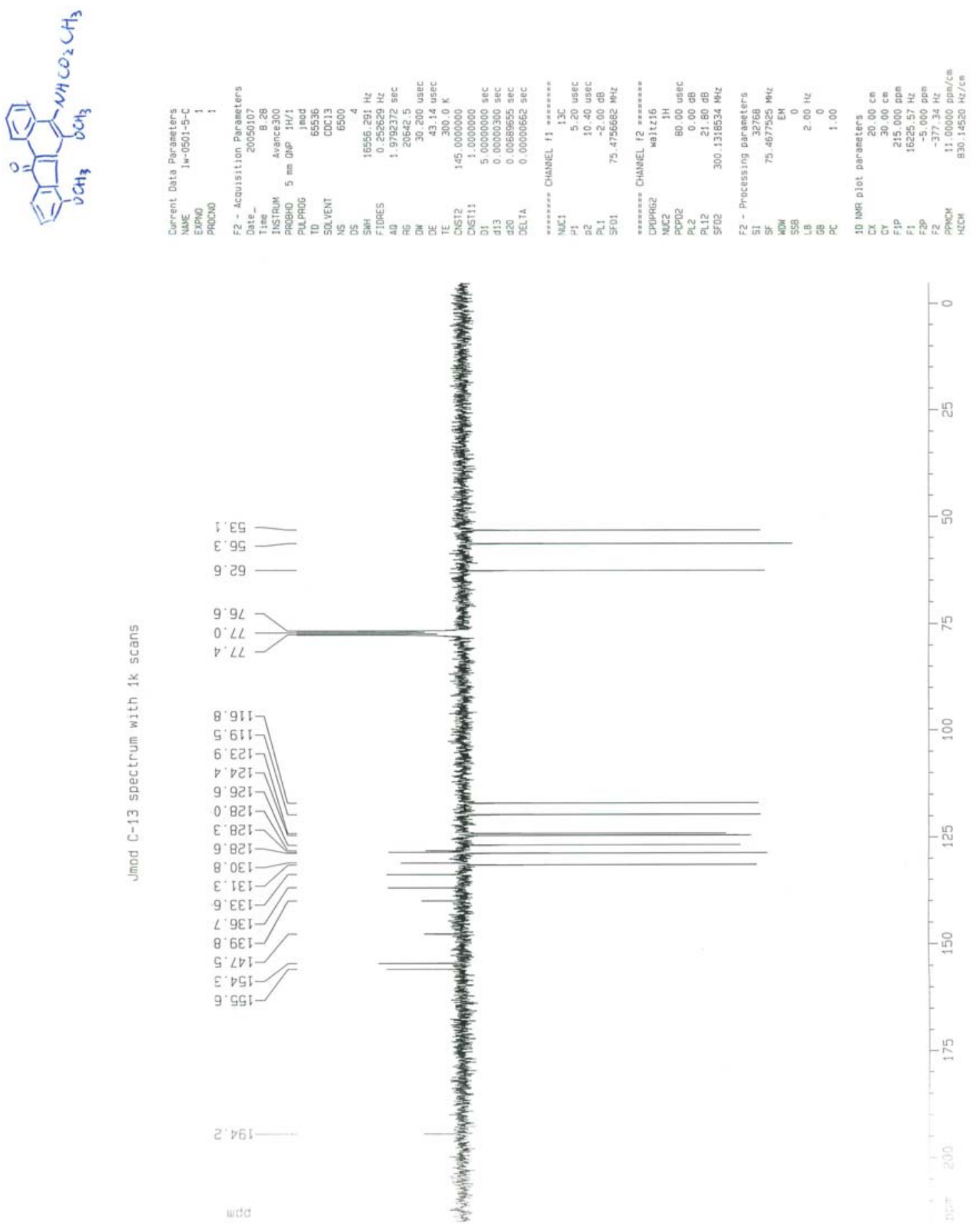


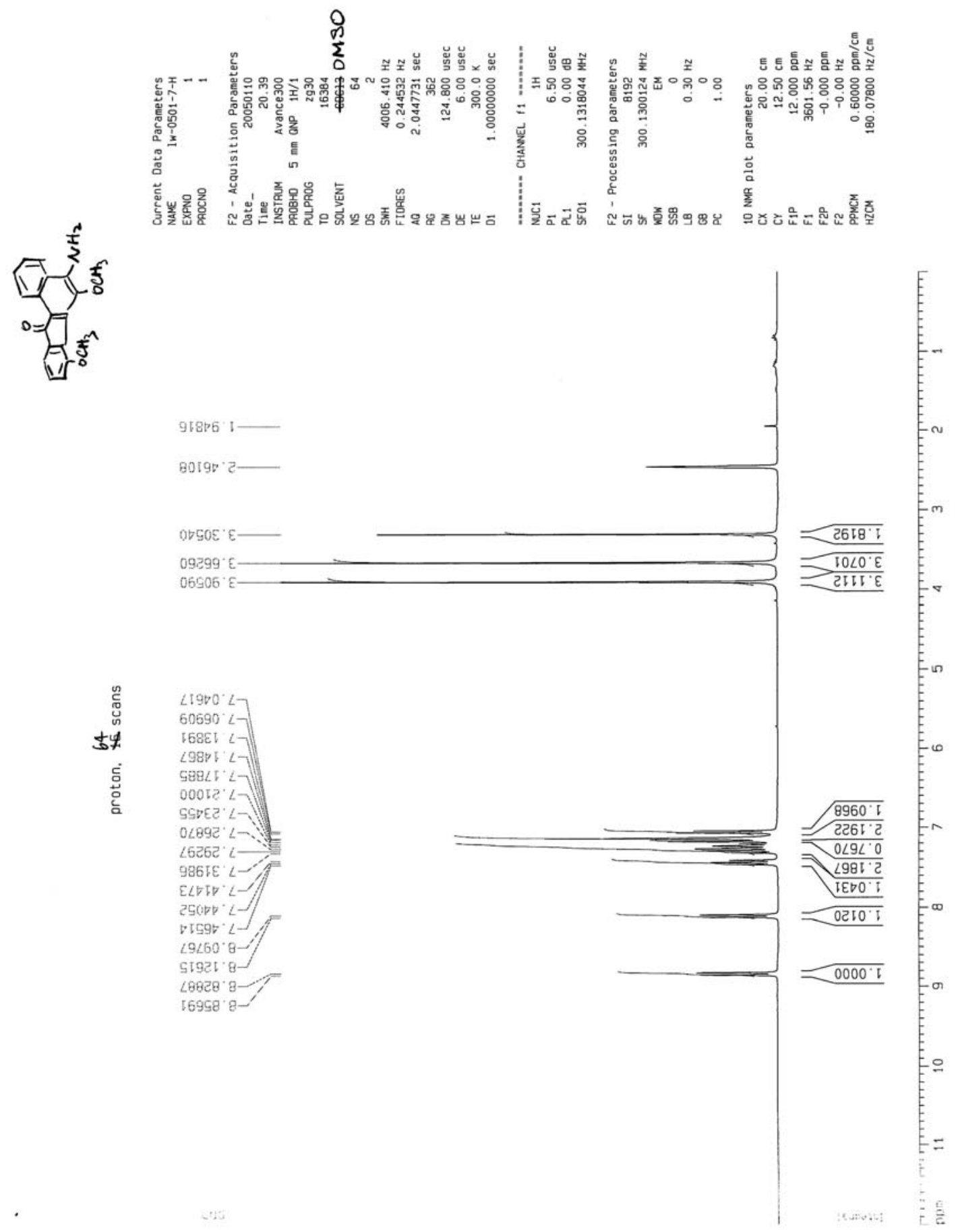



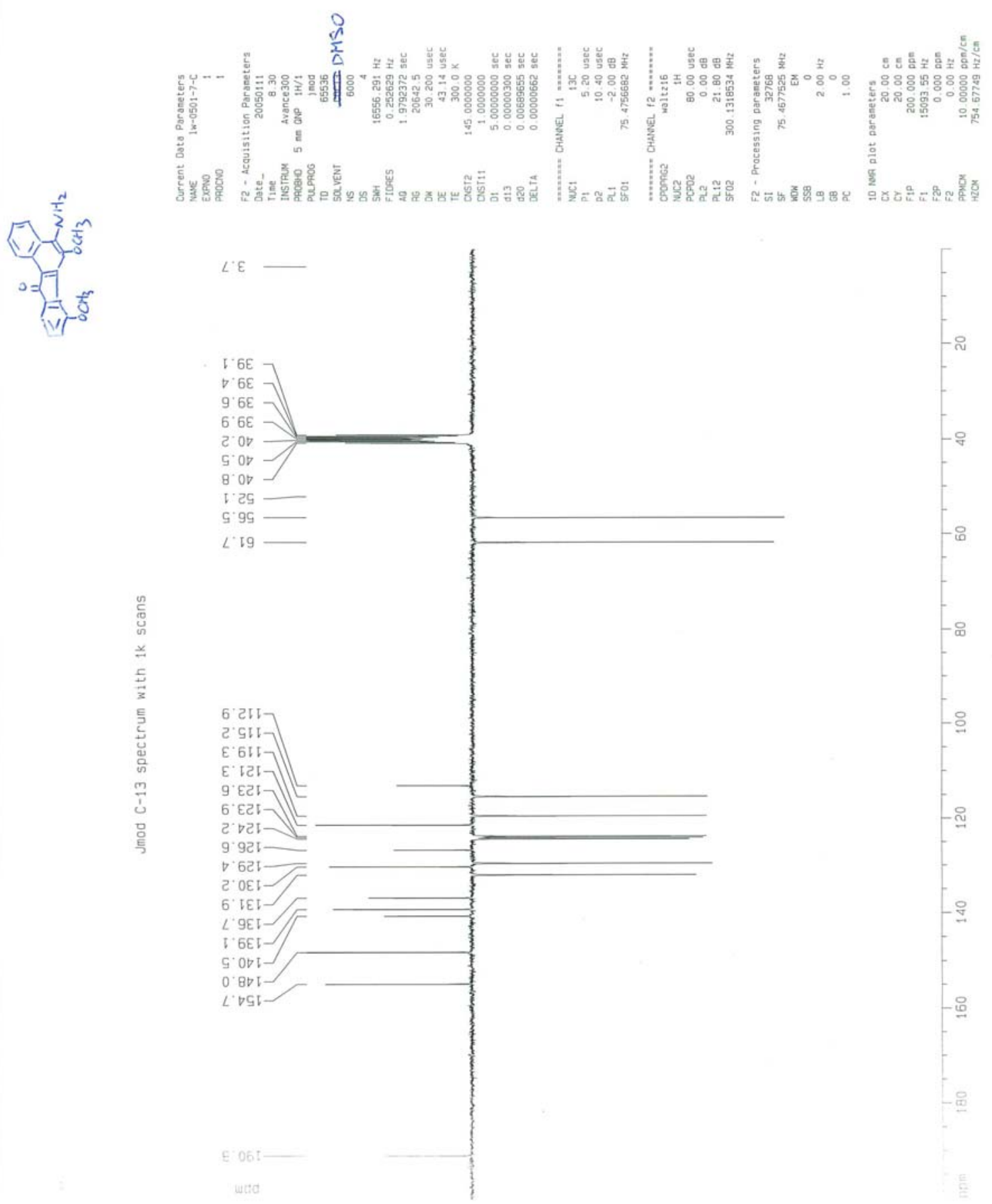


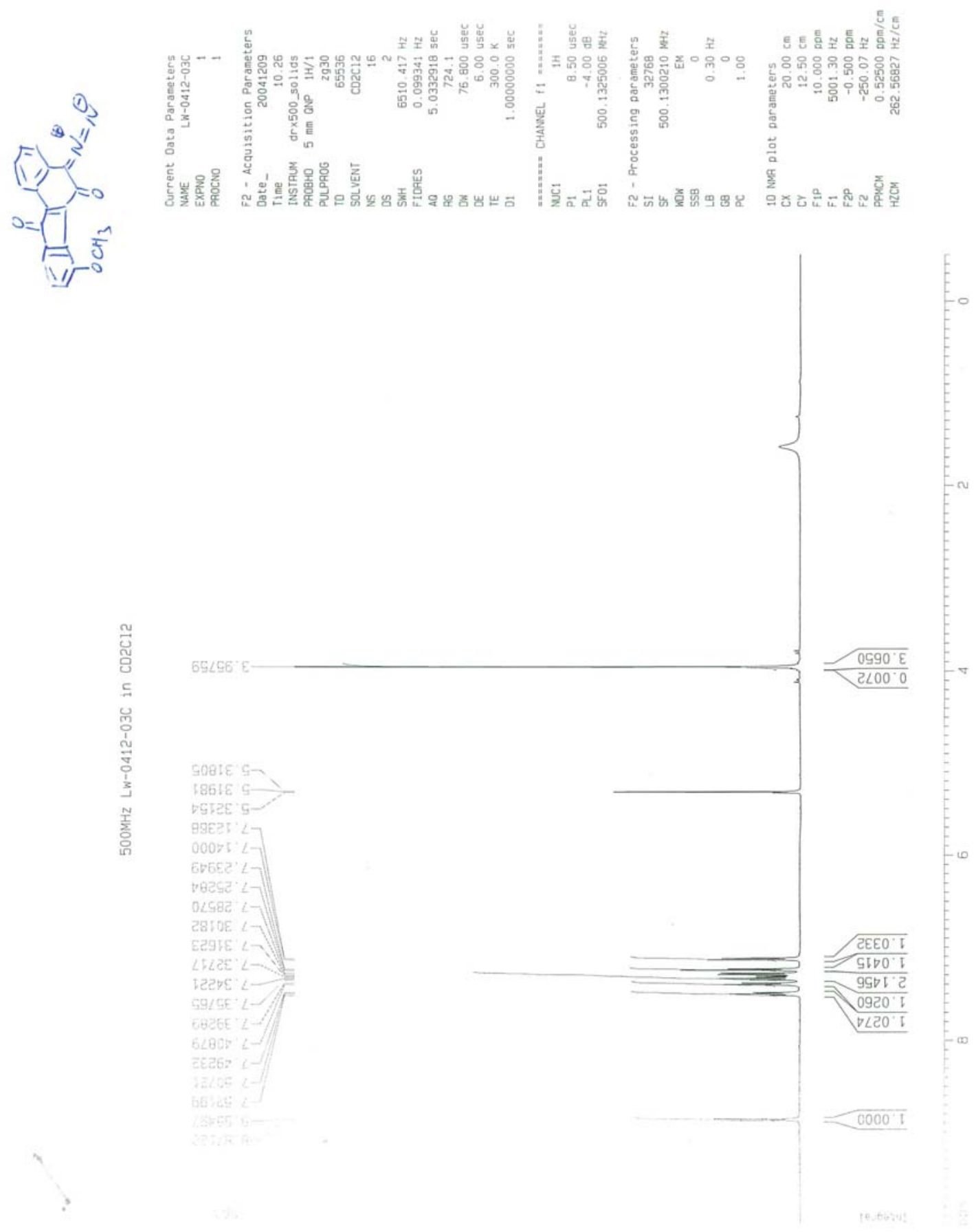



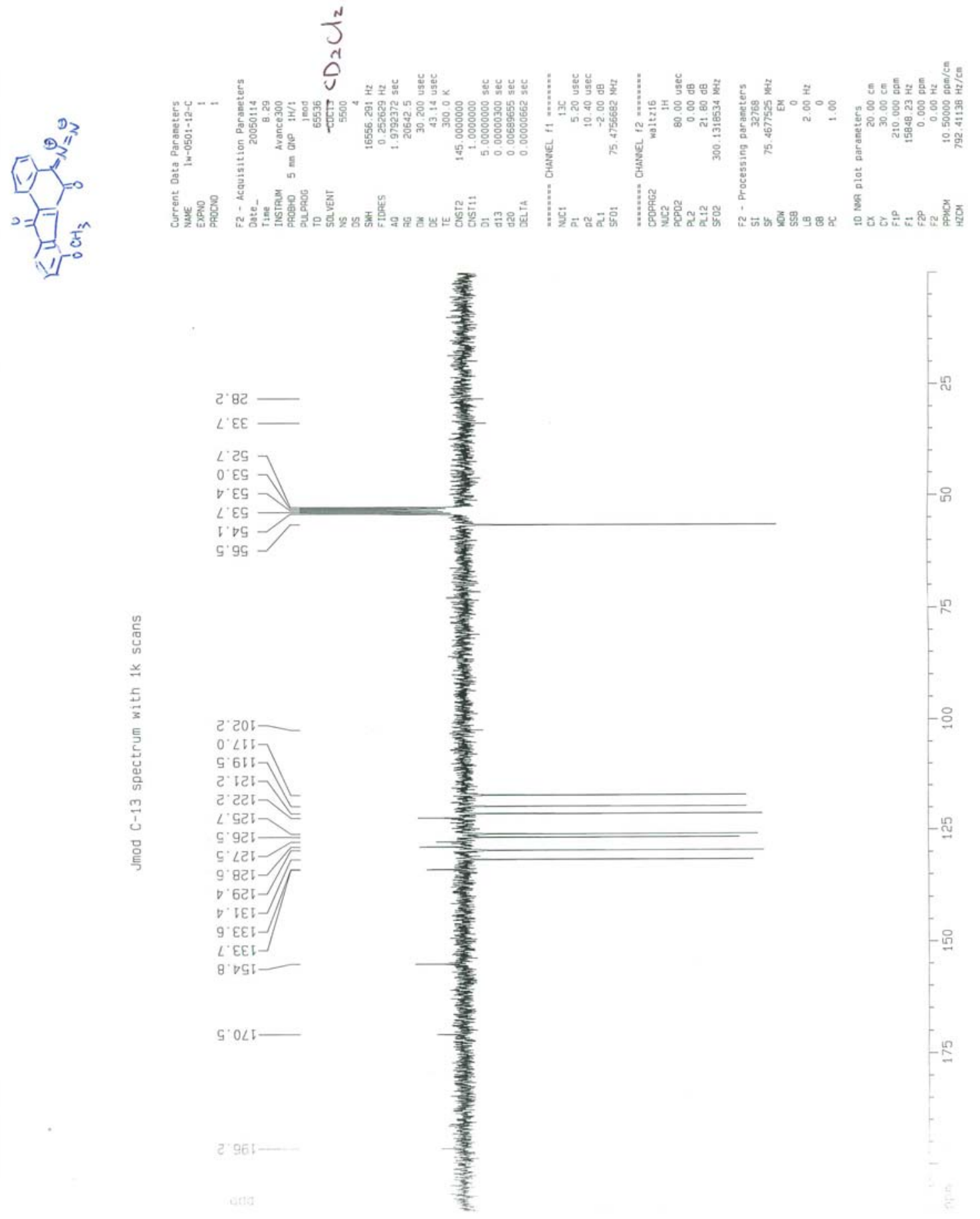


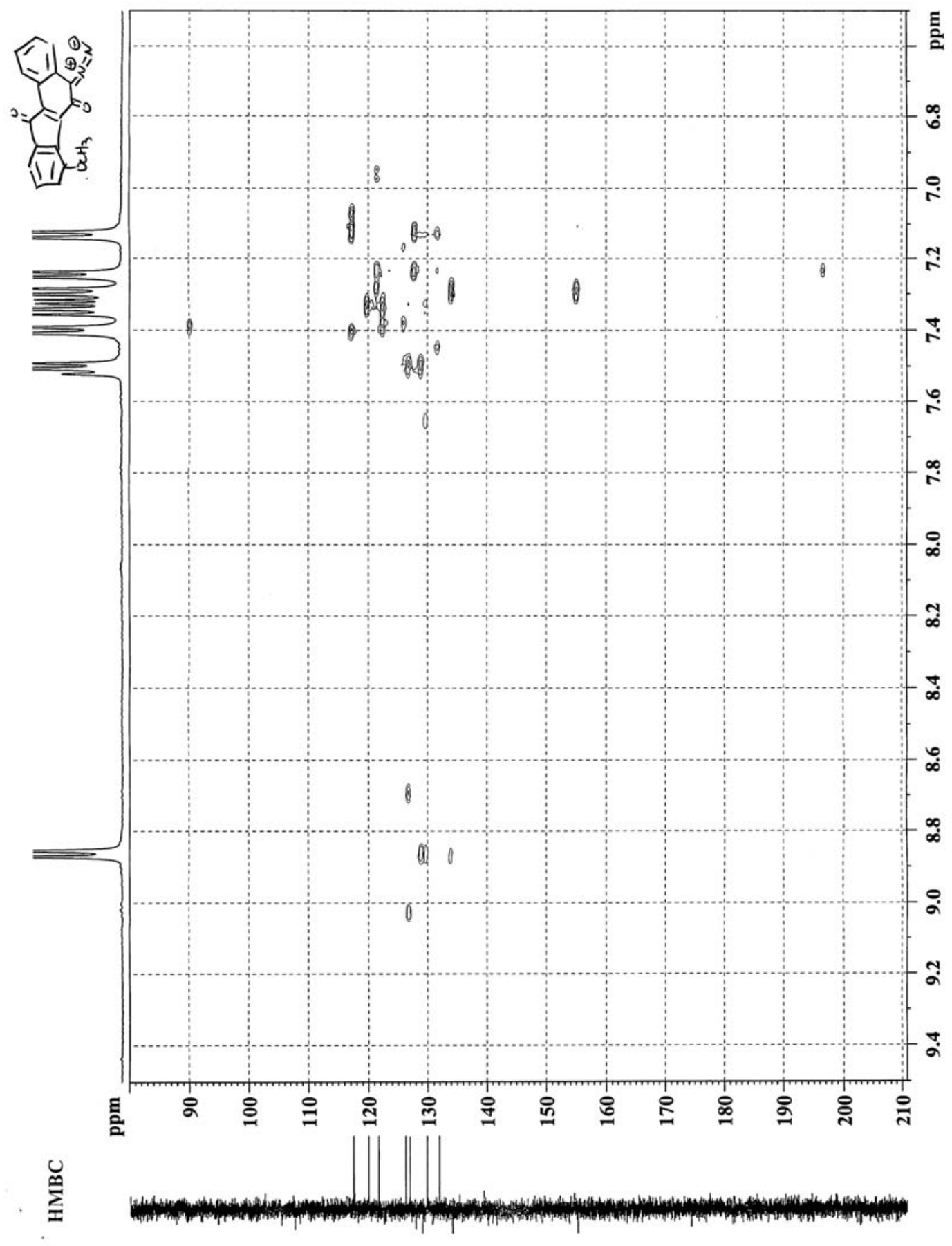




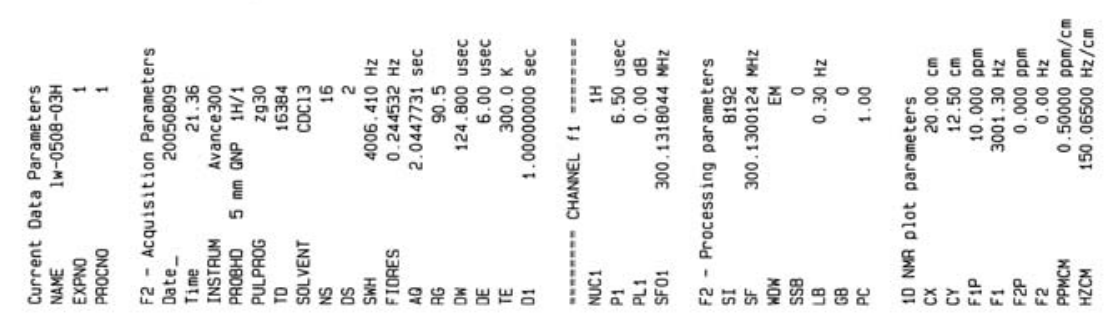

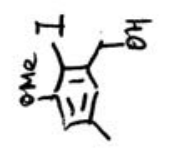

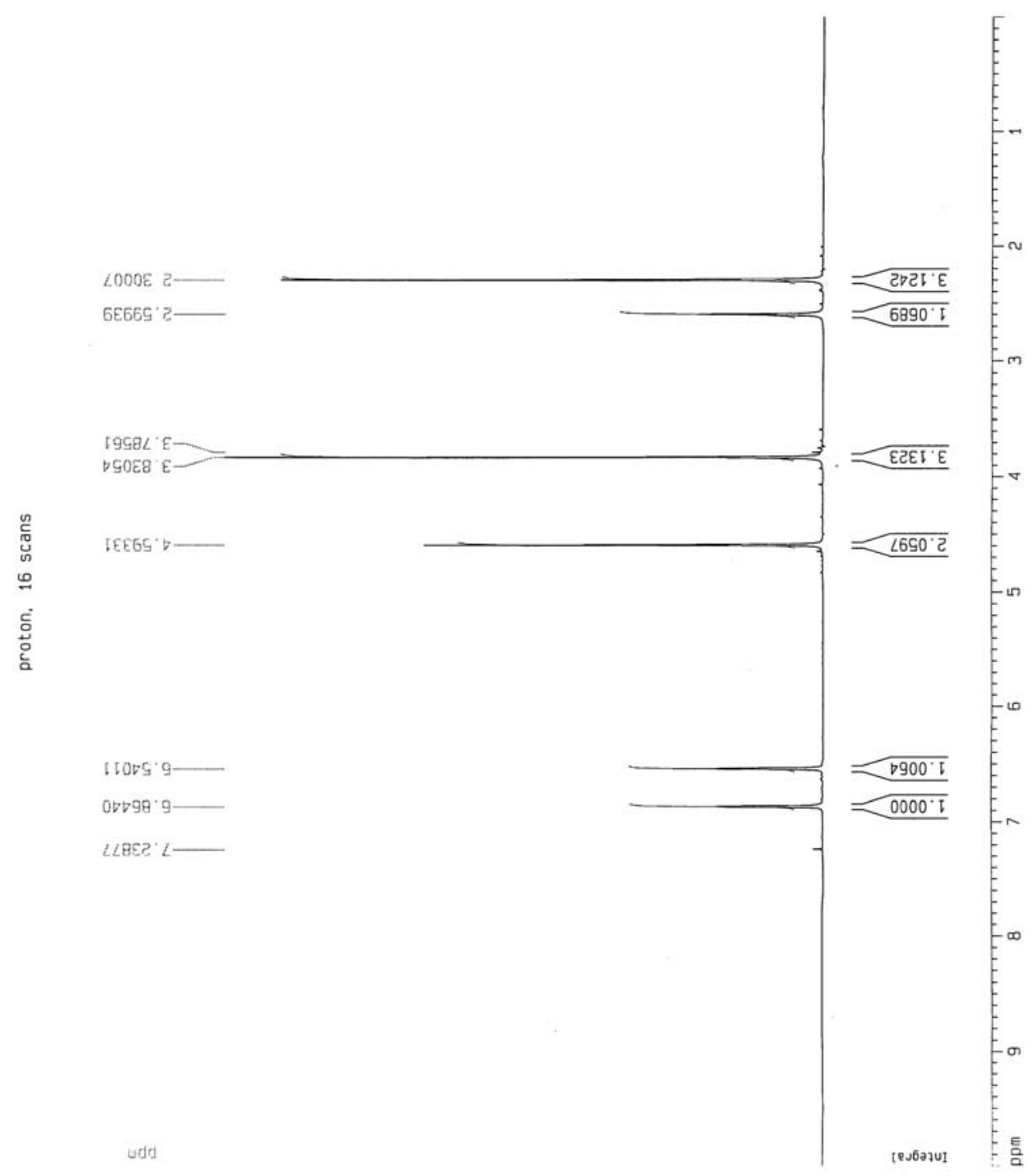




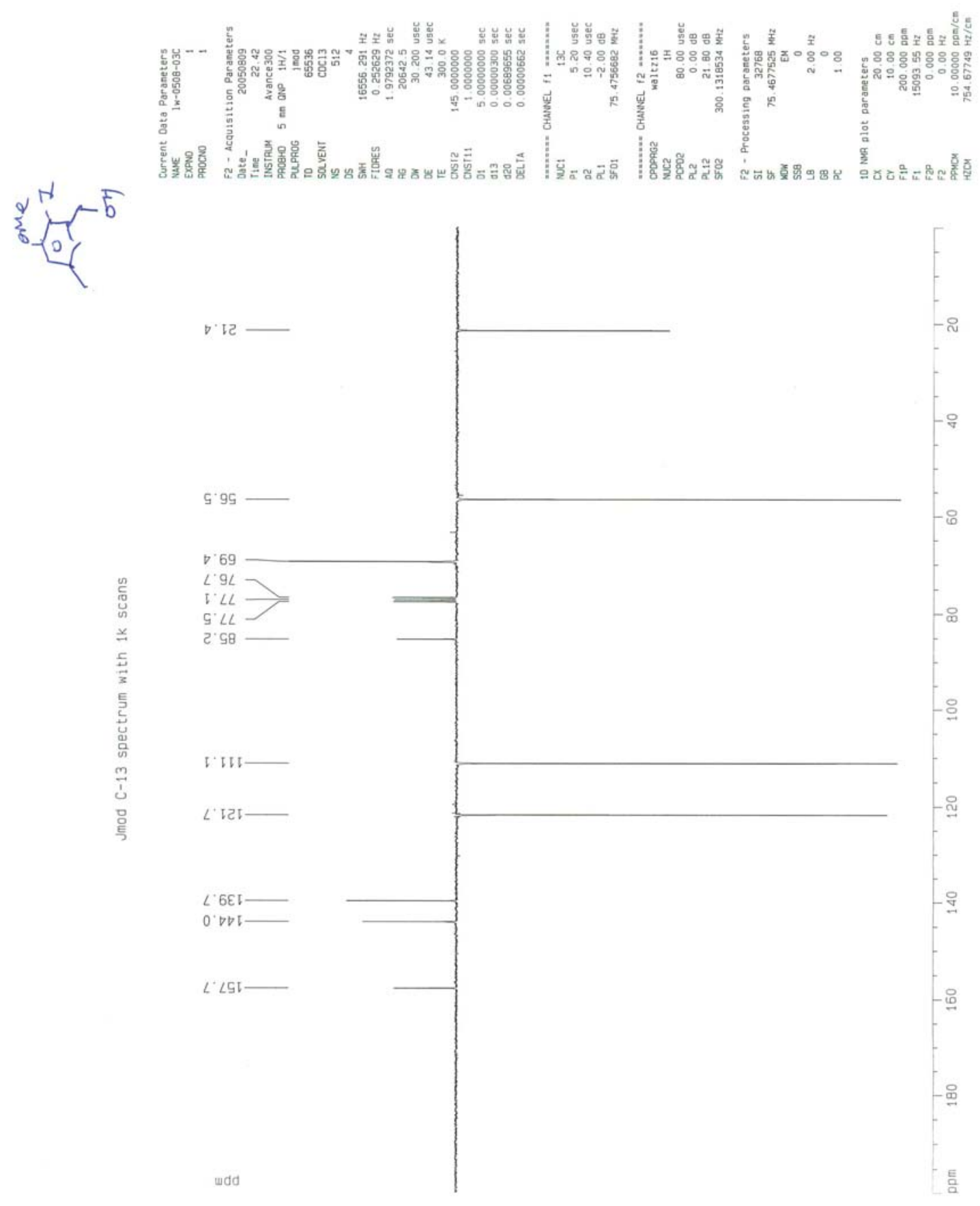



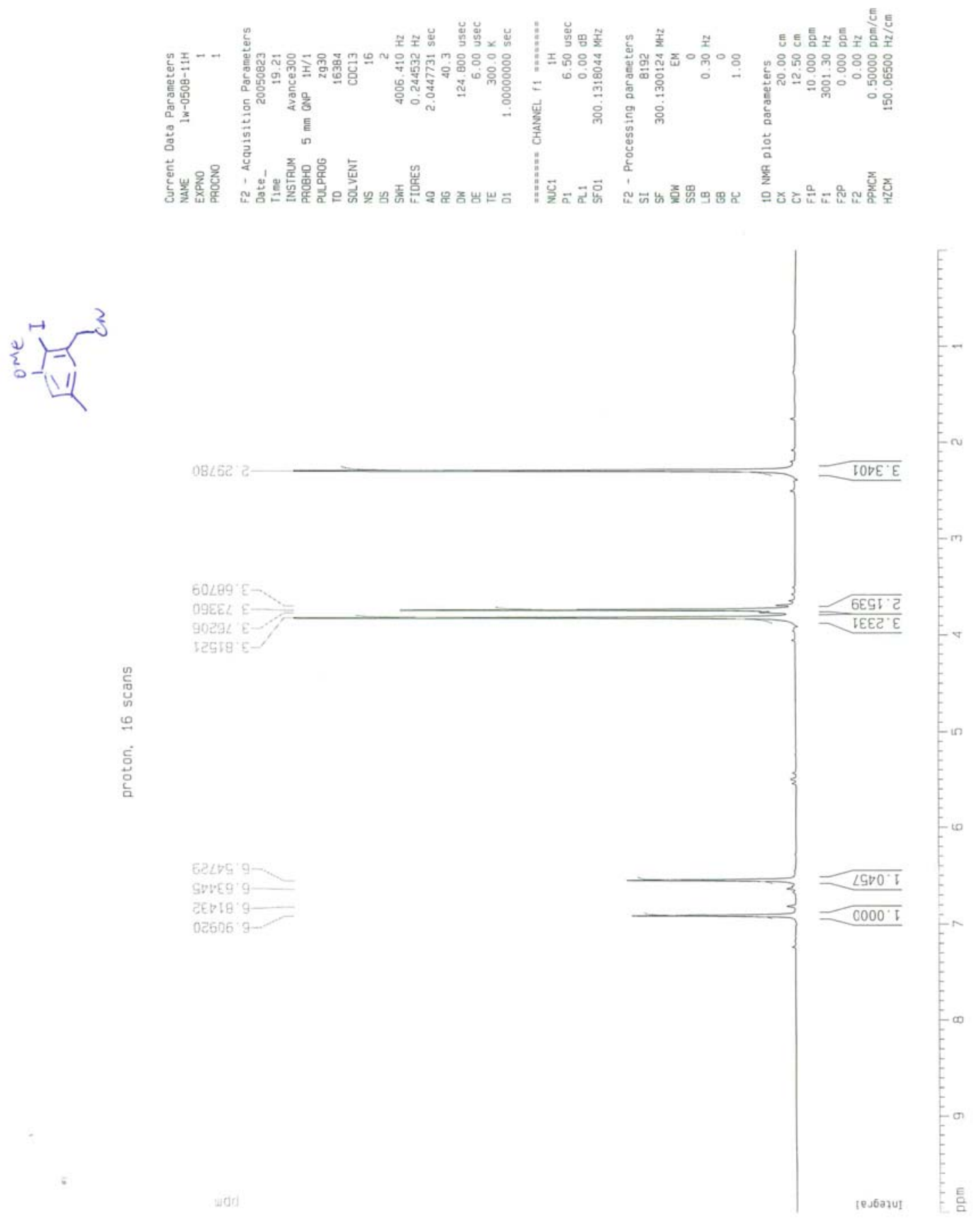

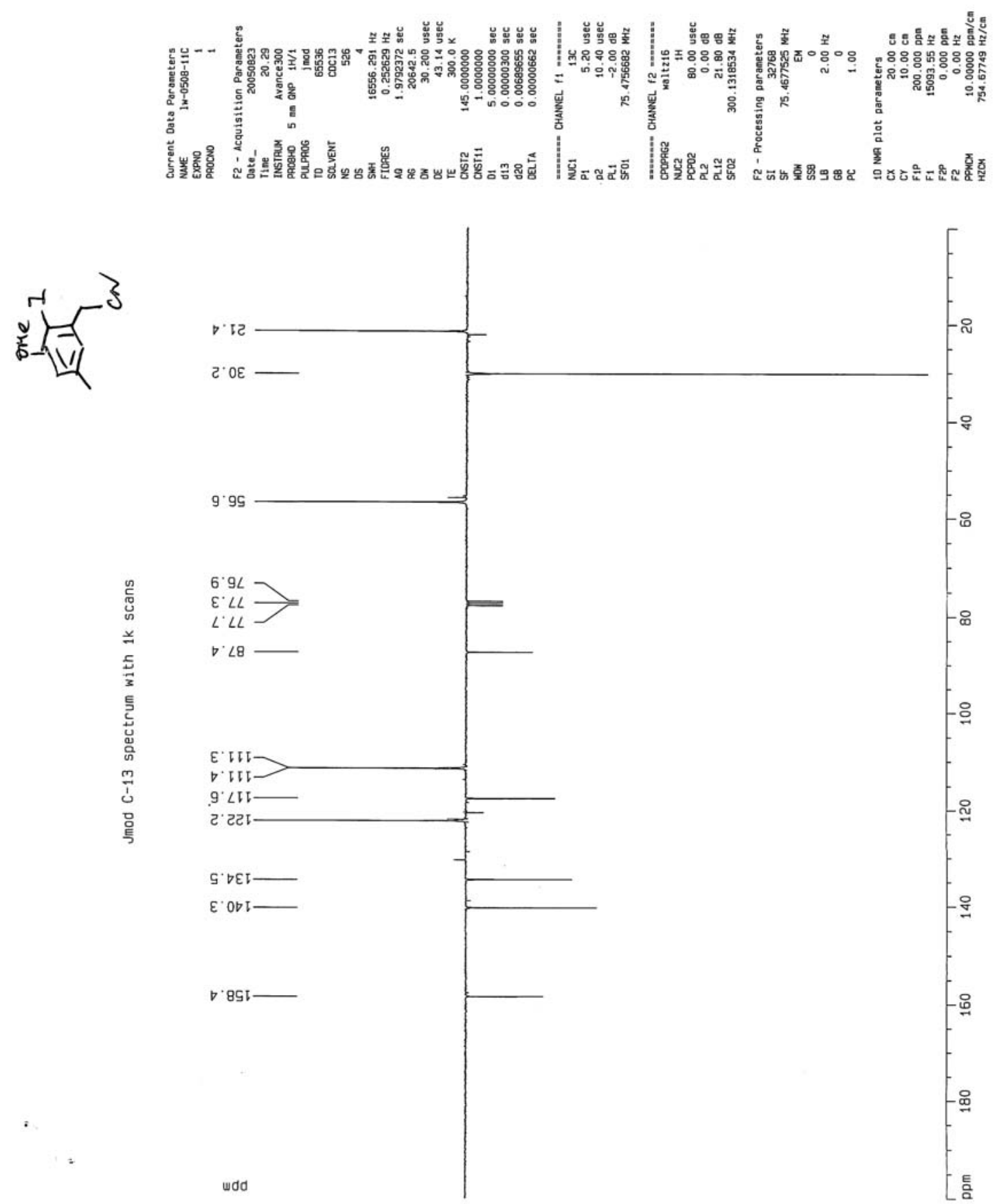

응

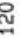

:

吕

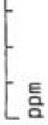



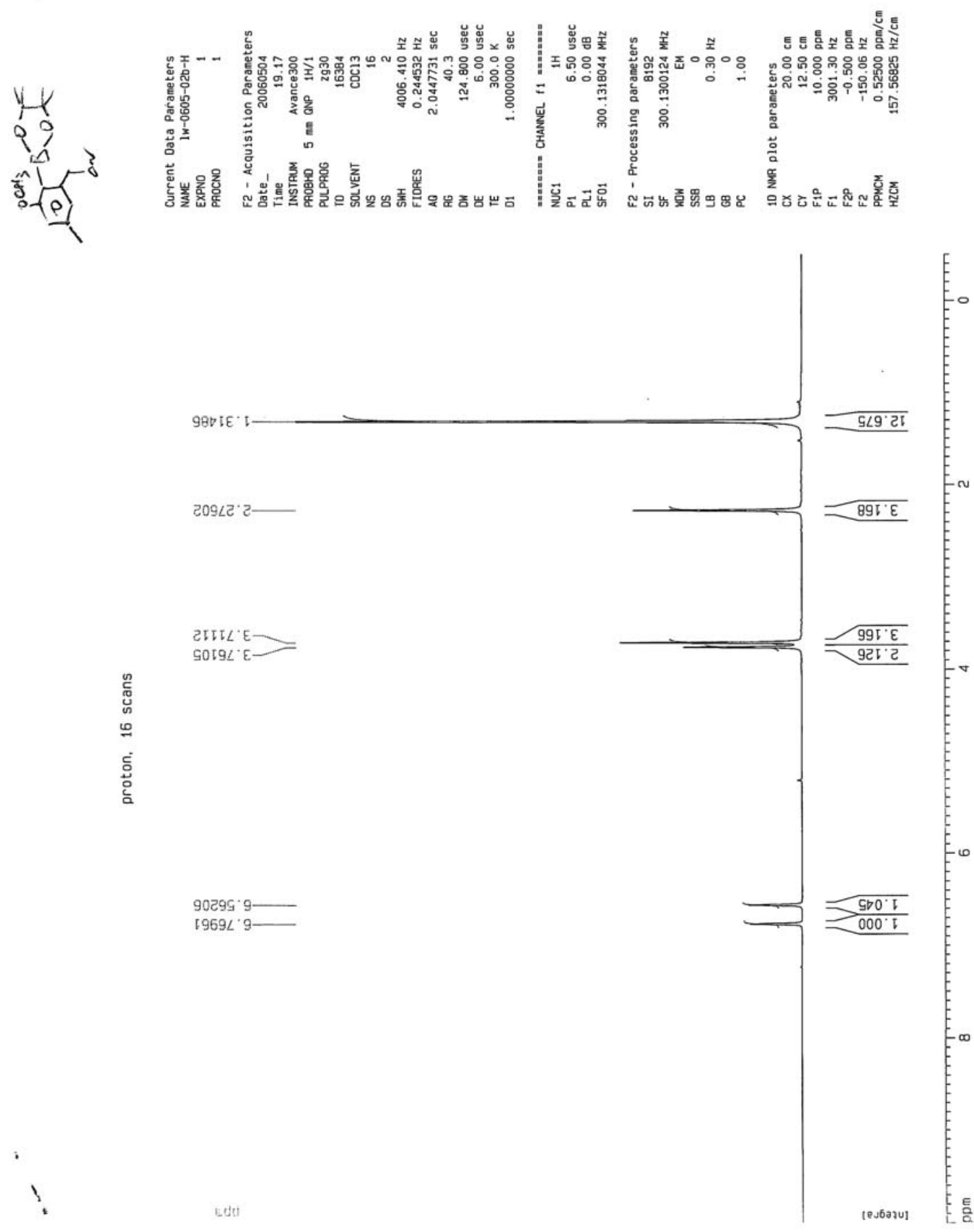


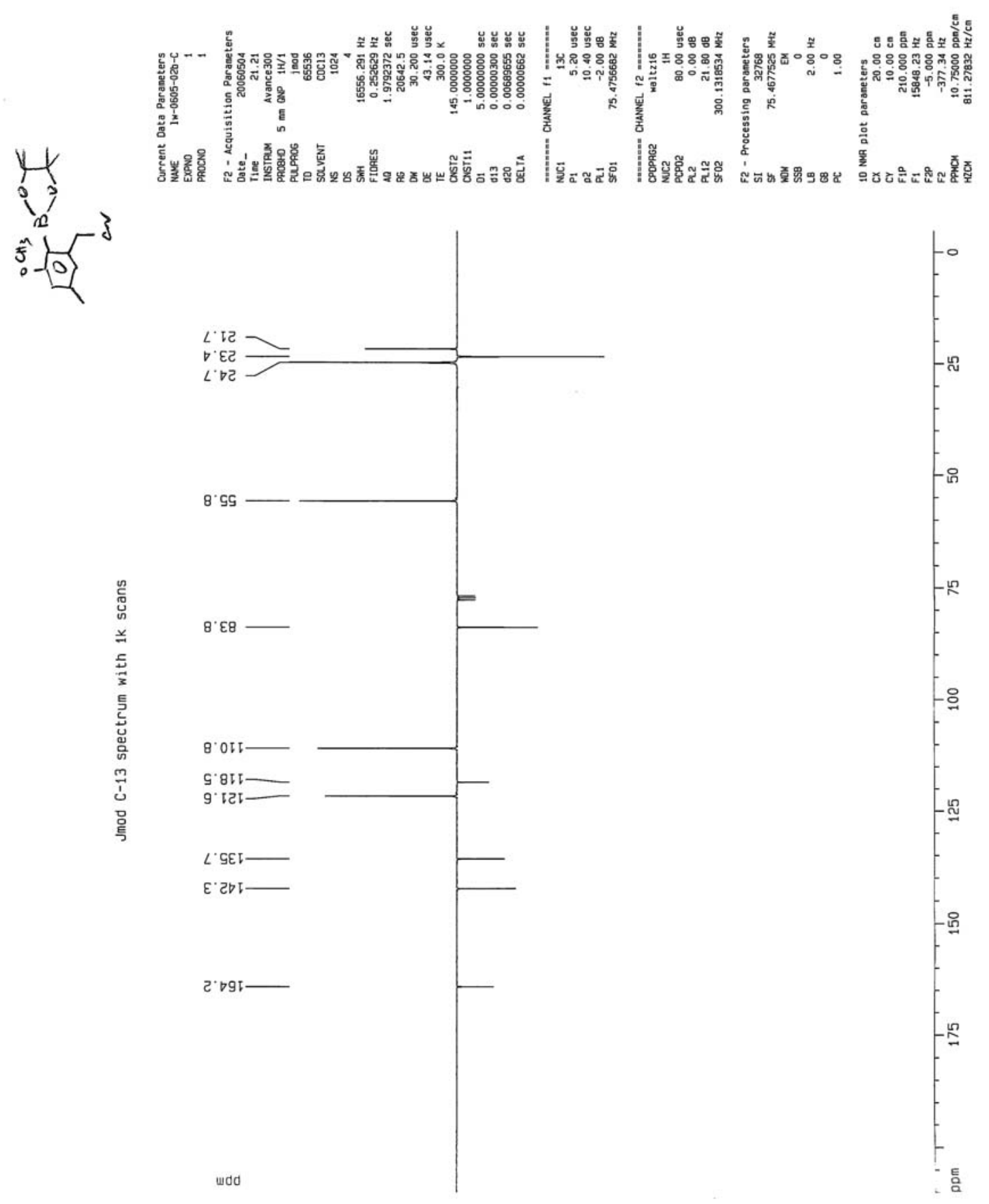




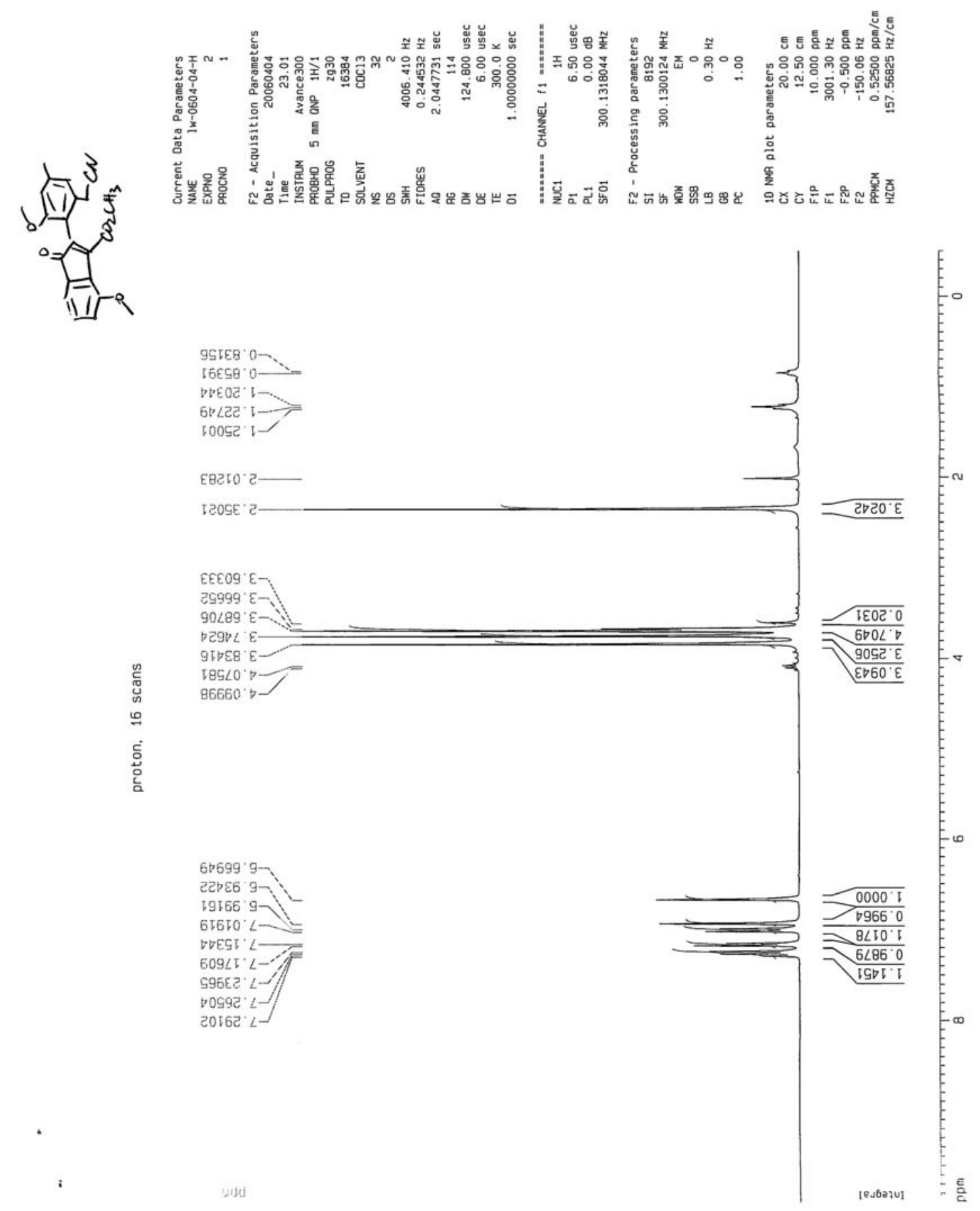



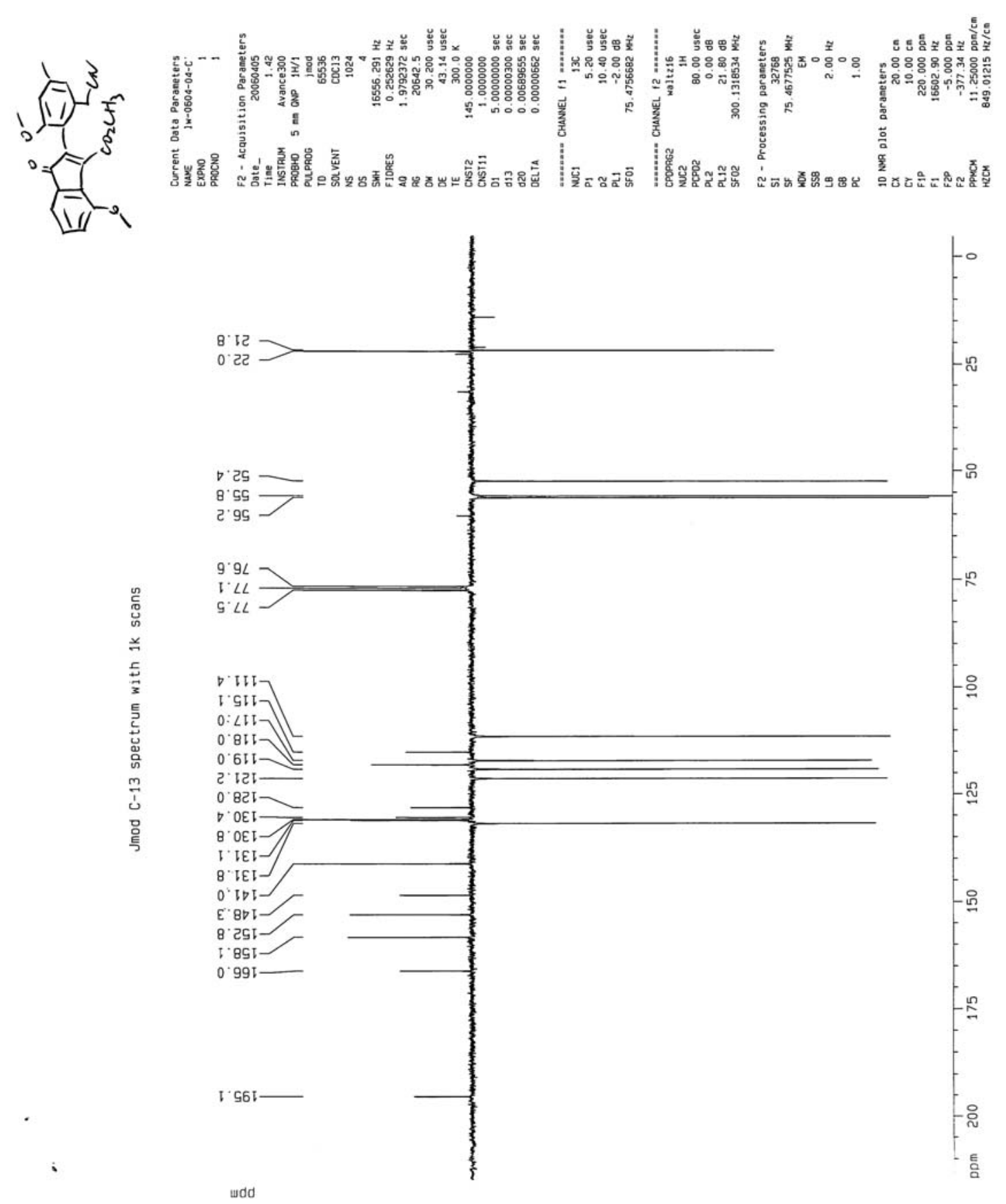


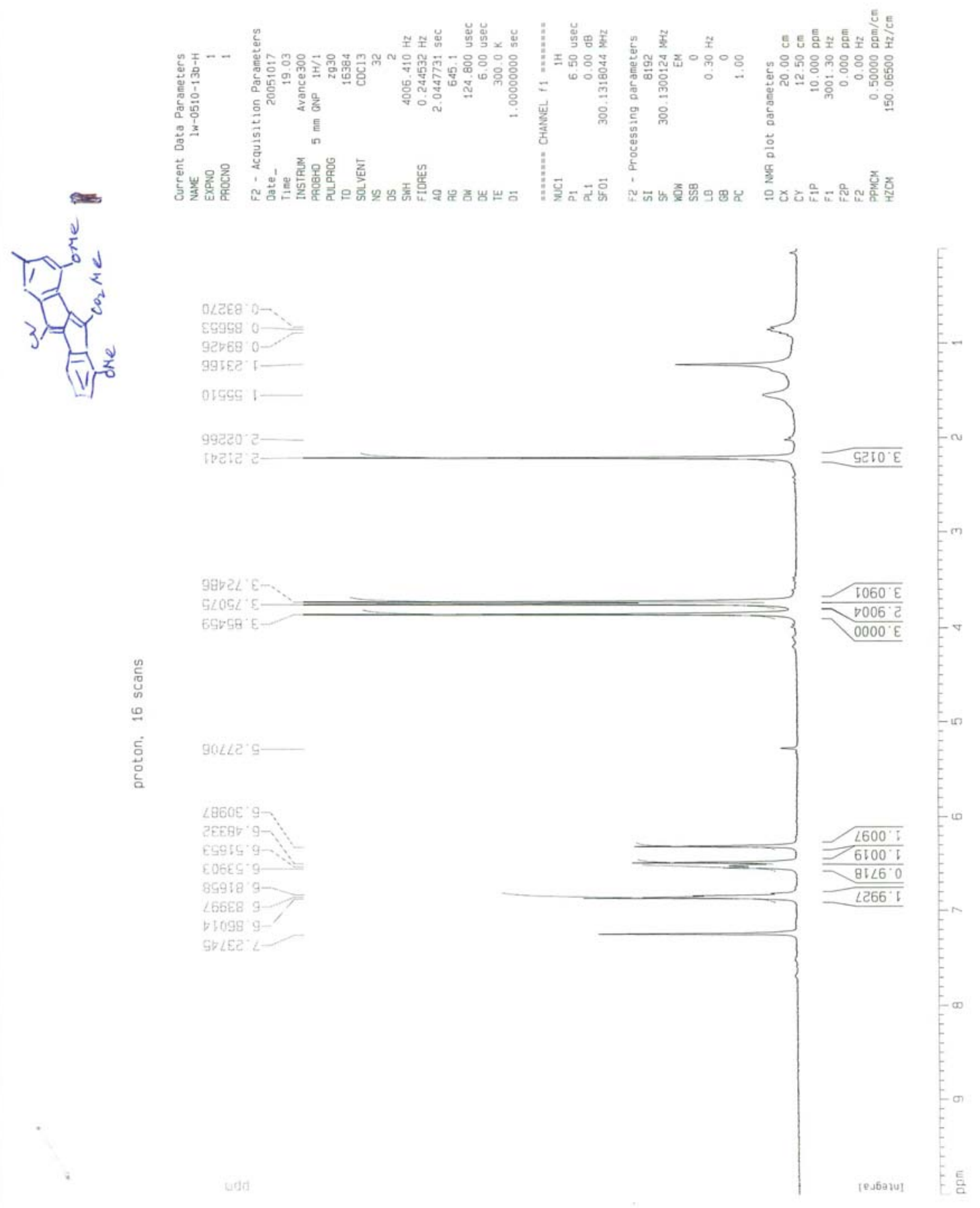



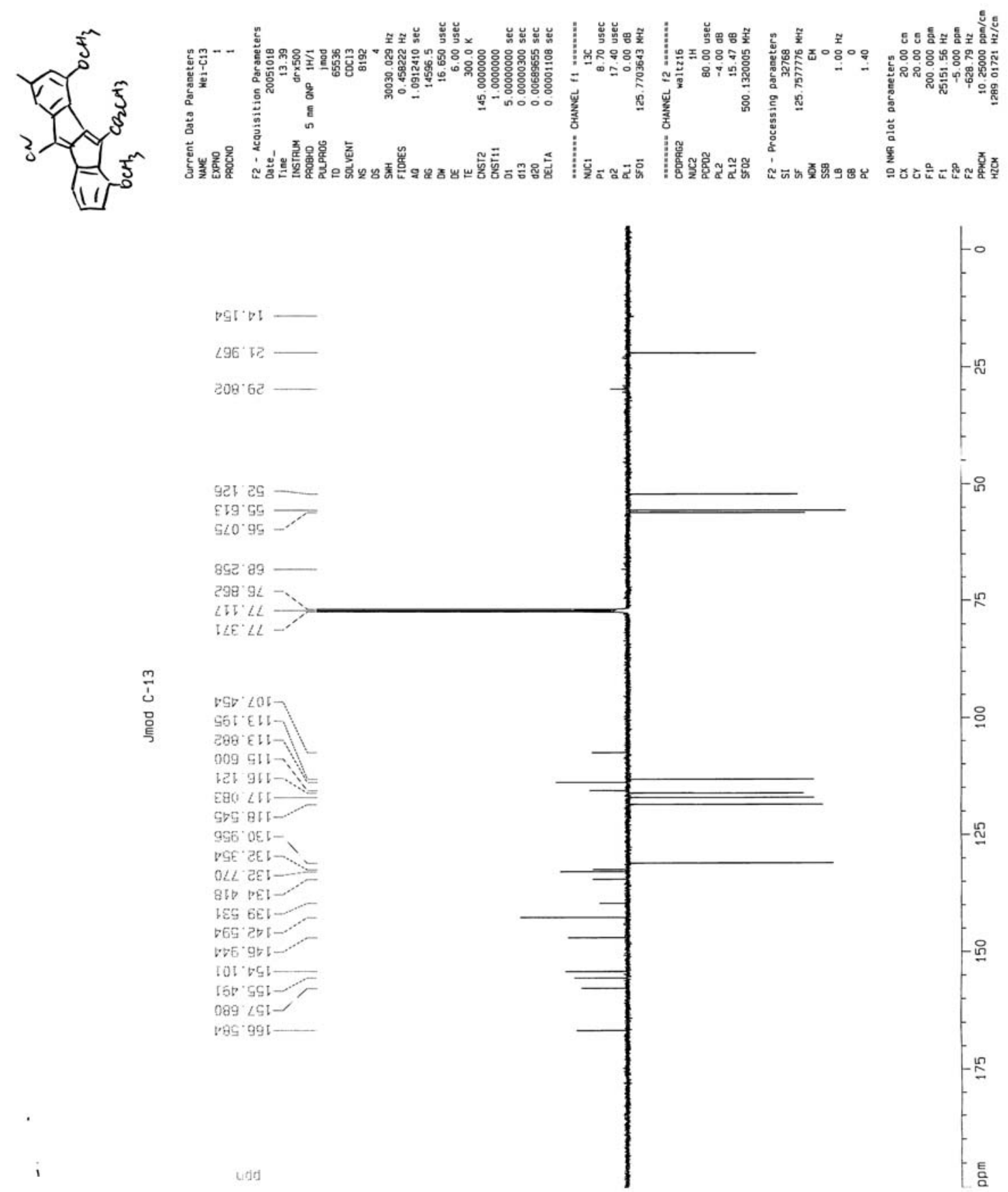


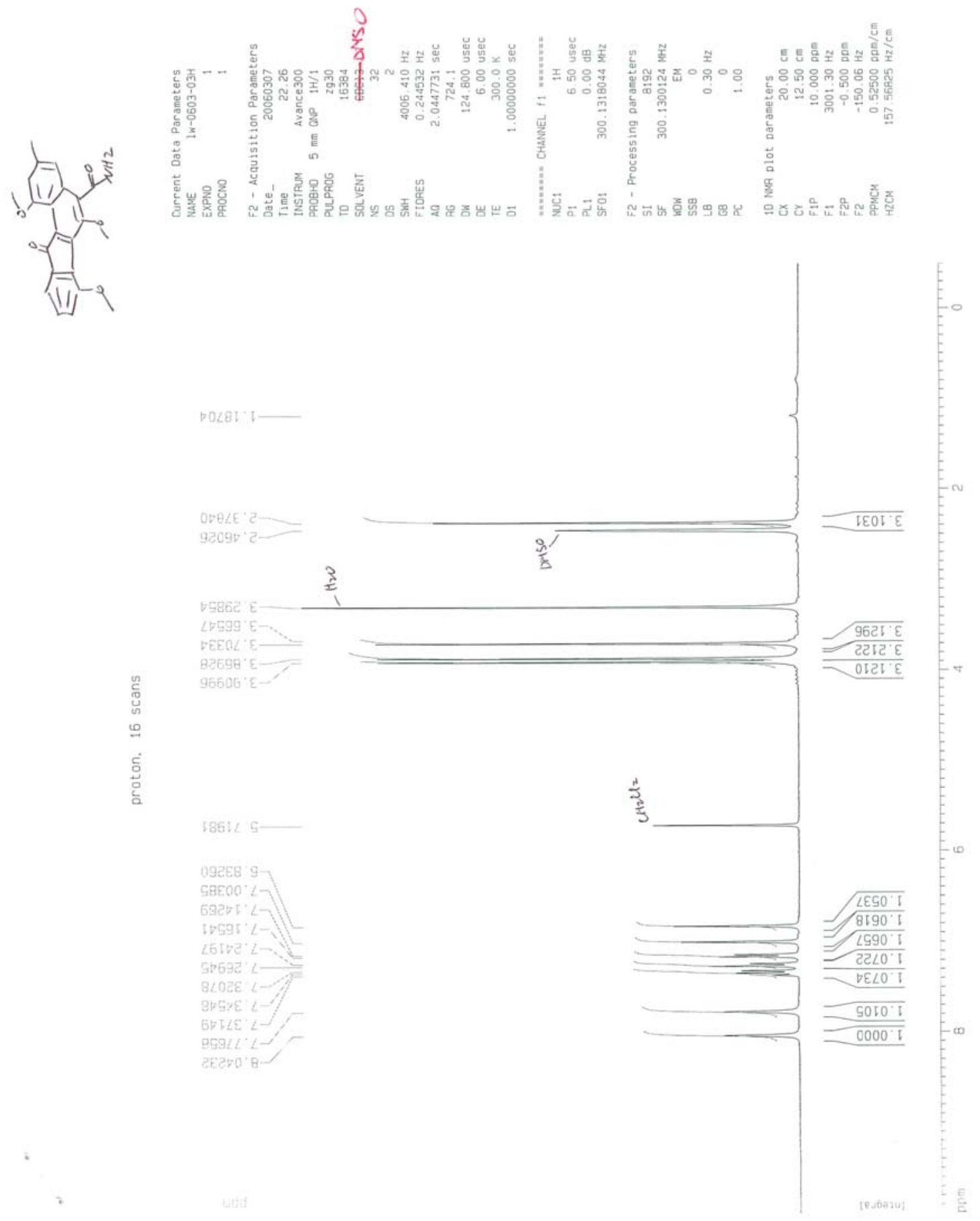




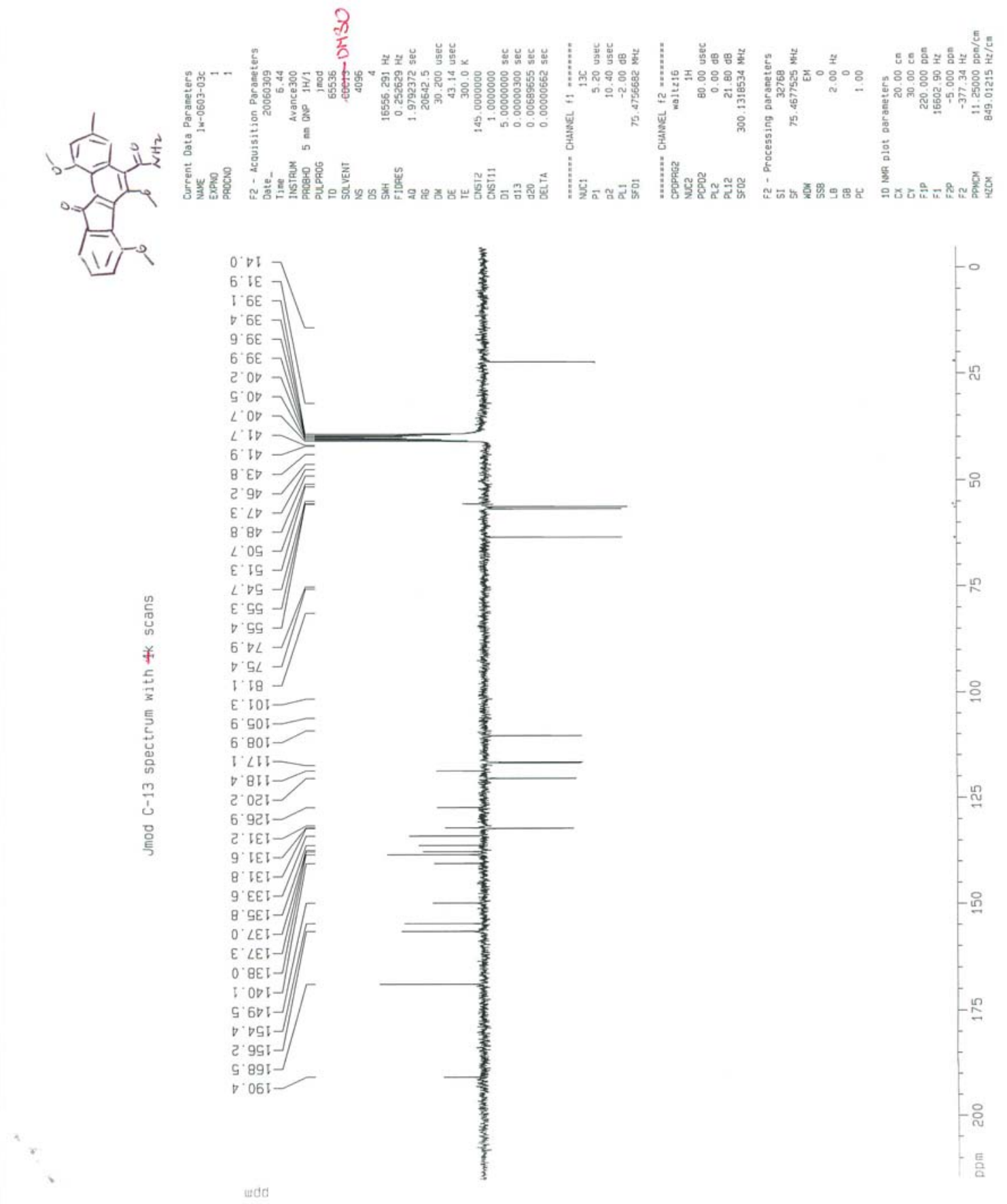




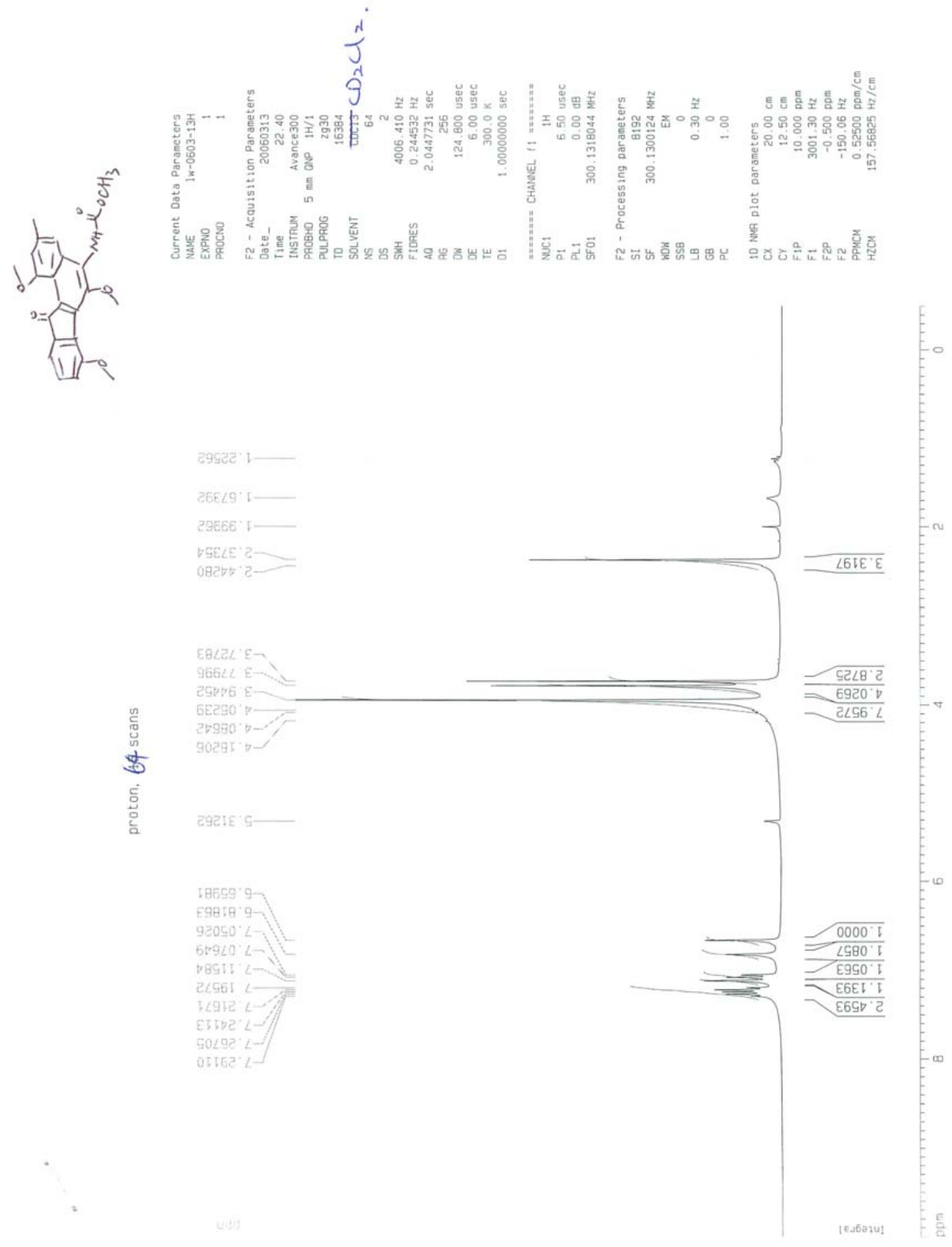



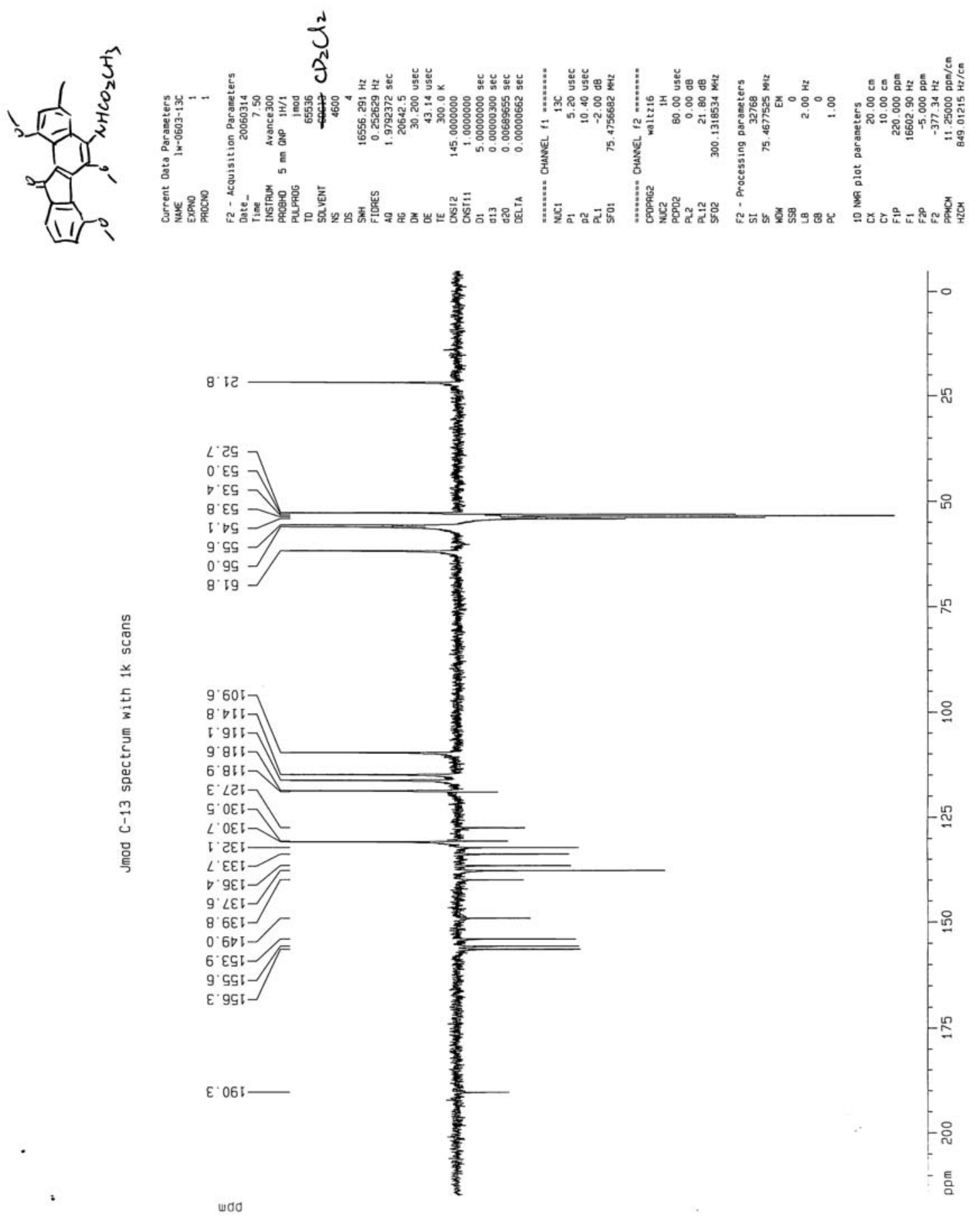


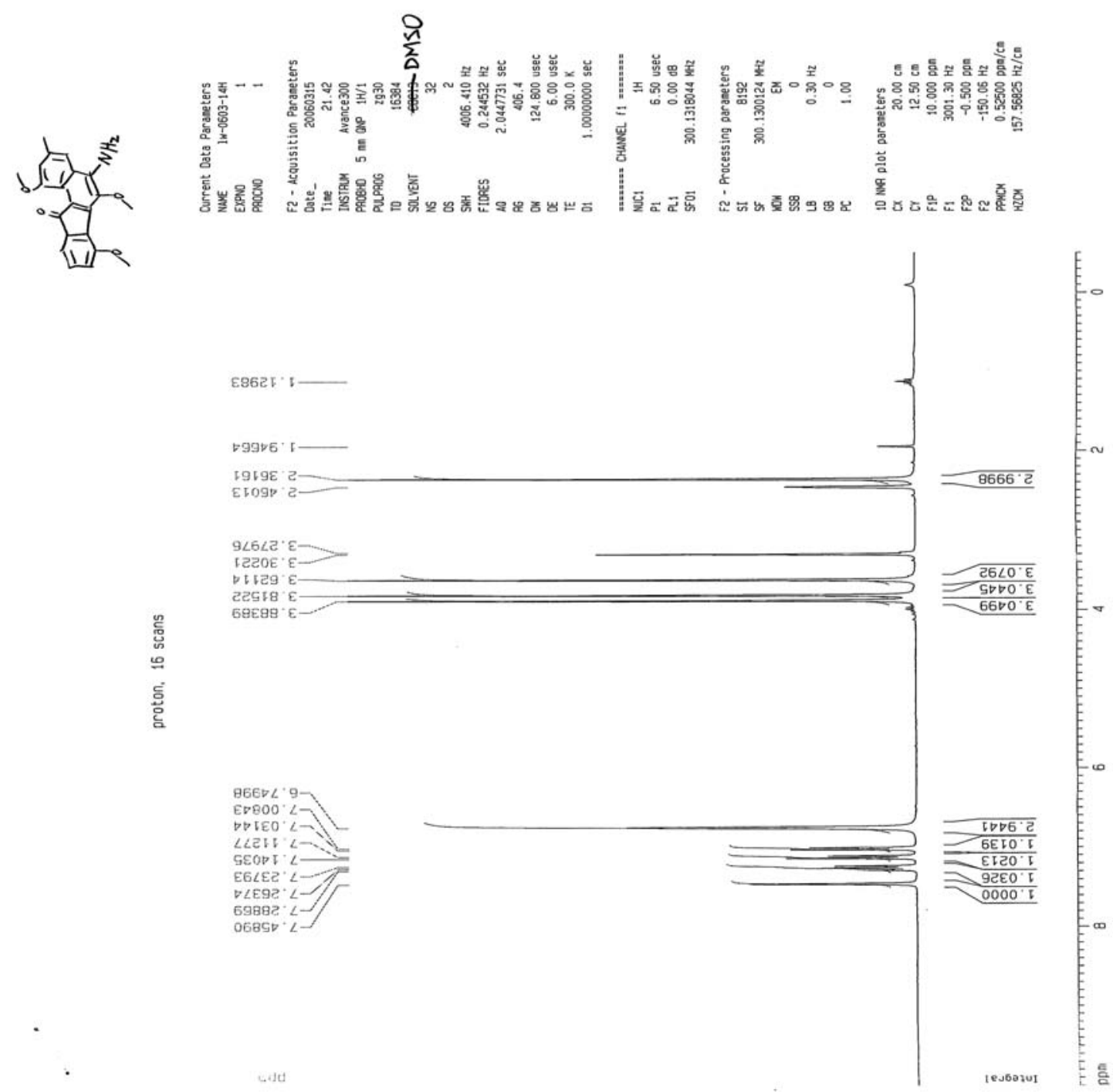




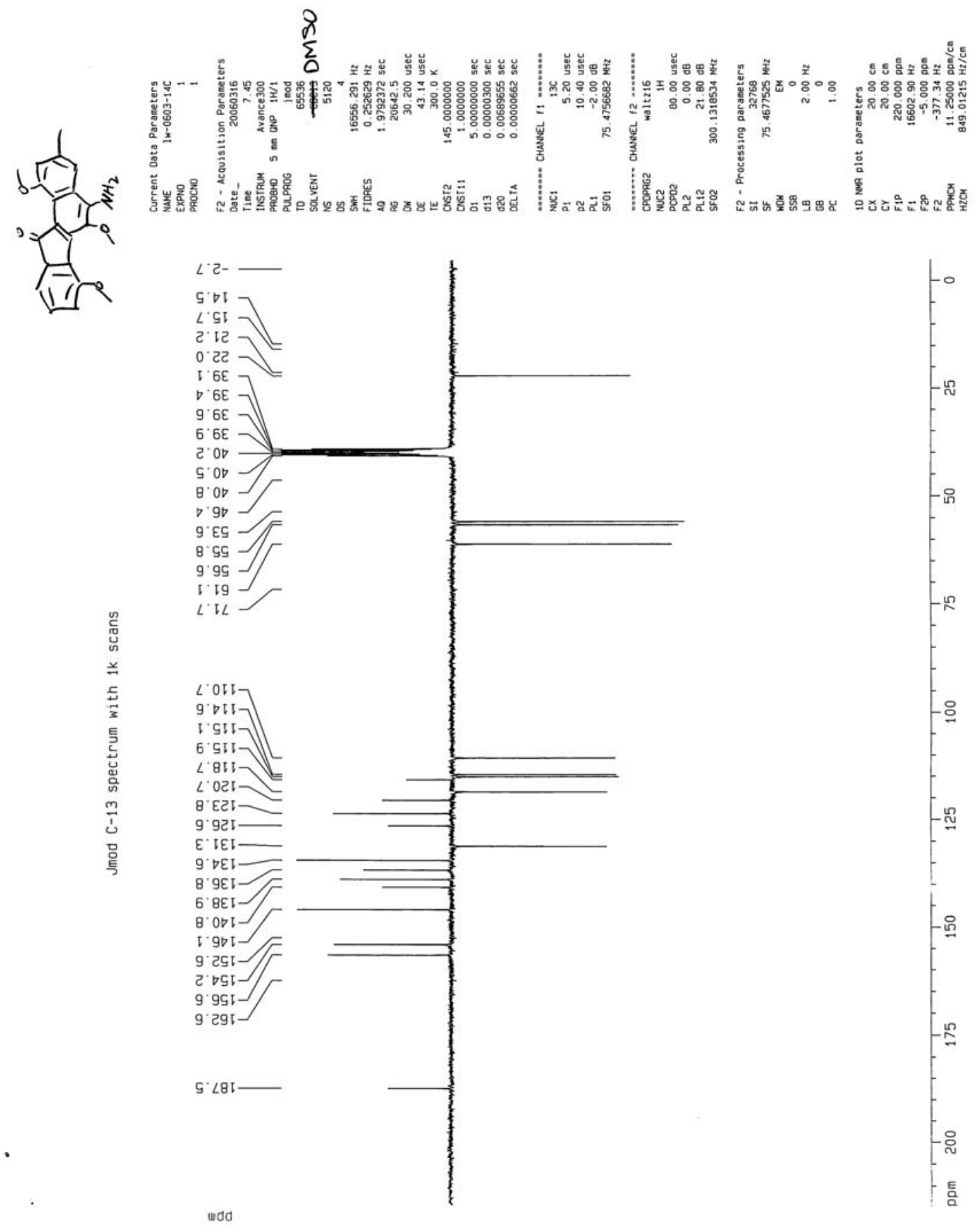




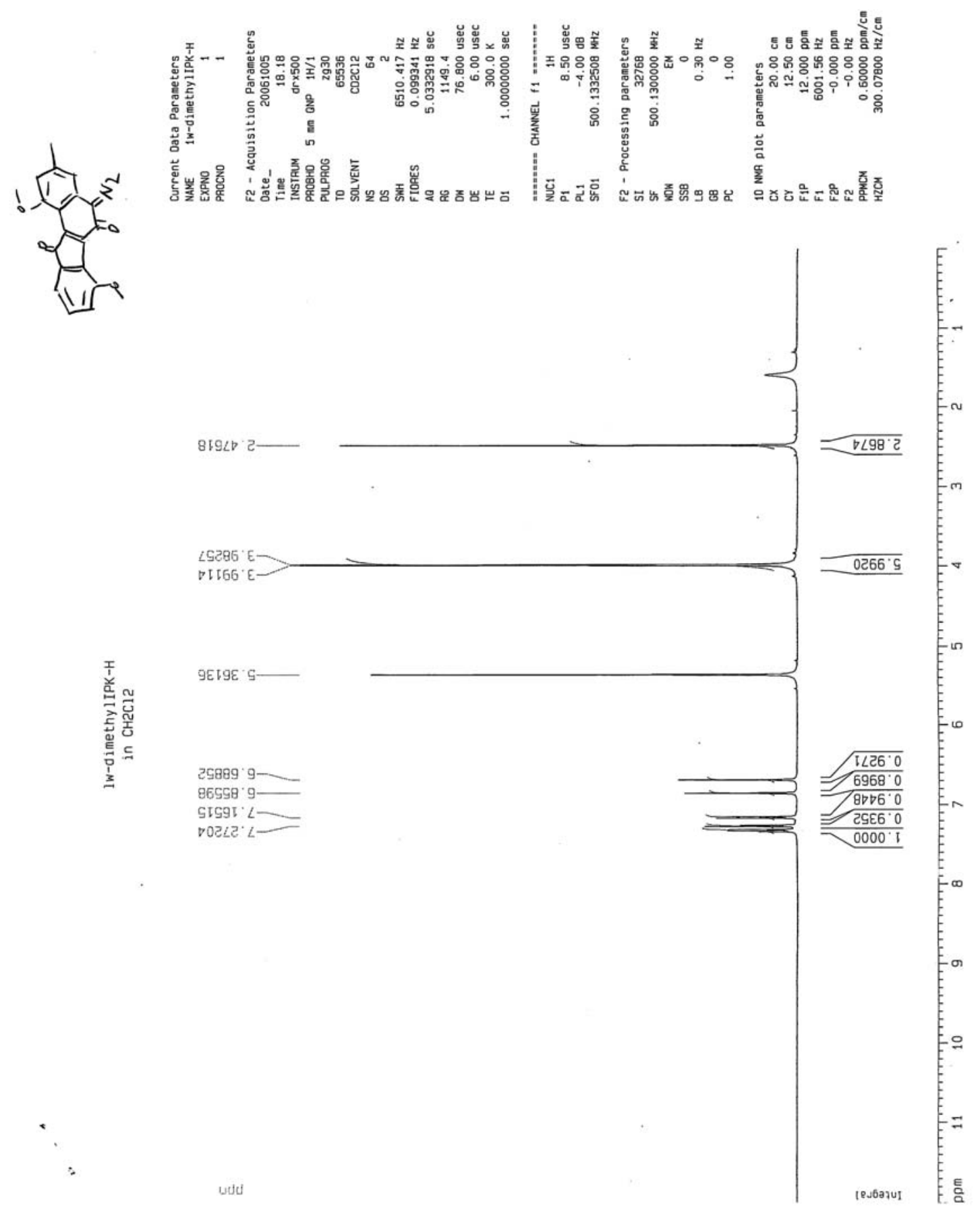



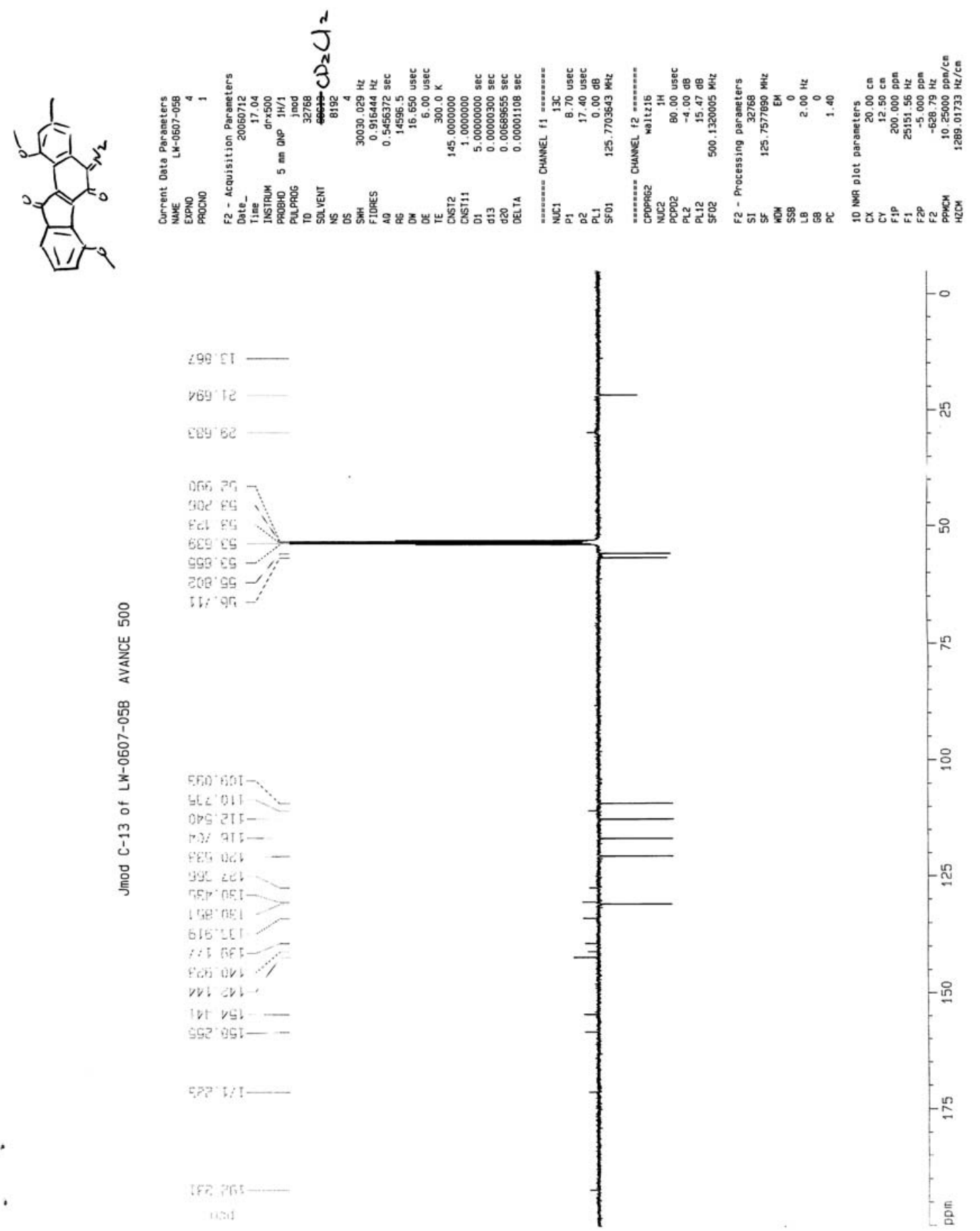


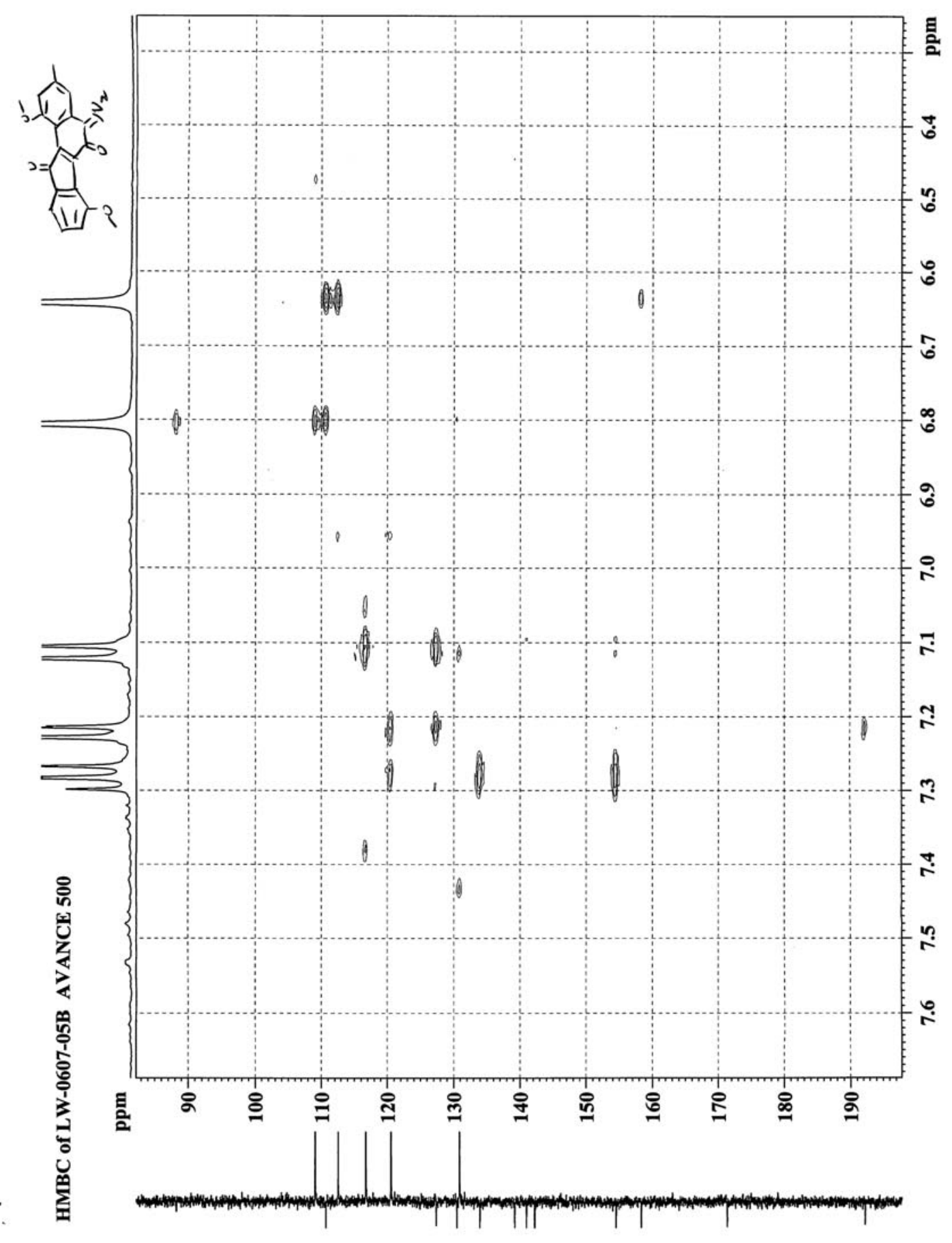




\section{II) Comparison of synthetic and natural isoprekinamycin}

Spectroscopic comparison of the synthetic and natural IPK was carried out in the following manner: (1) for ${ }^{1} \mathrm{H}$ NMR spectral comparison, saturated $\mathrm{CD}_{2} \mathrm{Cl}_{2}$ solutions of the synthetic and natural IPK were examined on a $500 \mathrm{MHz}$ NMR spectrometer; (2) for IR spectral comparison, saturated $\mathrm{CH}_{2} \mathrm{Cl}_{2}$ solutions of the synthetic and natural IPK were examined on a FT-IR spectrometer using a demountable liquid-cell IR kit (Aldrich Z11200-3) with two $\mathrm{CaF}_{2}$ windows $(32 \mathrm{~mm} \times 3 \mathrm{~mm}$ ) and a light path of $0.1 \mathrm{~mm}$, and the solvent and air backgrounds were deducted from the recorded spectra; (3) for HPLC retention time and UV-vis spectra comparison, the synthetic and natural IPK and also a mixture of both compounds were analyzed with a Waters HPLC system equipped with a photodiode array detector.

\section{${ }^{1} \mathrm{H}$ NMR (500 MHz in $\mathrm{CD}_{2} \mathrm{Cl}_{2}$ )}

\begin{tabular}{|c|c|}
\hline Natural IPK (ppm) & Synthetic IPK (ppm) \\
\hline $12.32(\mathrm{~s}, 1 \mathrm{H})$ & $12.32(\mathrm{~s}, 1 \mathrm{H})$ \\
$11.61(\mathrm{~s}, 1 \mathrm{H})$ & $11.61(\mathrm{~s}, 1 \mathrm{H})$ \\
$7.26(\mathrm{dd}, 7.0 \mathrm{~Hz}, 0.7 \mathrm{~Hz}, 1 \mathrm{H})$ & $7.26(\mathrm{~d}, 6.7 \mathrm{~Hz}, 1 \mathrm{H})$ \\
$7.18(\mathrm{t}, 7.6 \mathrm{~Hz}, 1 \mathrm{H})$ & $7.18(\mathrm{t}, 7.6 \mathrm{~Hz}, 1 \mathrm{H})$ \\
$7.06(\mathrm{dd}, 8.3 \mathrm{~Hz}, 0.8 \mathrm{~Hz}, 1 \mathrm{H})$ & $7.06(\mathrm{~d}, 8.3 \mathrm{~Hz}, 1 \mathrm{H})$ \\
$6.71(\mathrm{~s}, 1 \mathrm{H})$ & $6.72(\mathrm{~s}, 1 \mathrm{H})$ \\
$6.69(\mathrm{~s}, 1 \mathrm{H})$ & $6.69(\mathrm{~s}, 1 \mathrm{H})$ \\
$2.41(\mathrm{~s}, 1 \mathrm{H})$ & $2.41(\mathrm{~s}, 1 \mathrm{H})$ \\
\hline
\end{tabular}


IR frequency (saturated $\mathrm{CH}_{2} \mathrm{Cl}_{2}$ solution)

\begin{tabular}{|c|c|}
\hline Natural IPK $\left(\mathbf{c m}^{-\mathbf{1}}\right)$ & Synthetic IPK $\left(\mathbf{c m}^{\mathbf{- 1}}\right)$ \\
\hline 3688.5 & 3686.1 \\
3600.9 & 3600.7 \\
2926.6 & 2926.6 \\
2855.3 & 2855.0 \\
$2126.0^{\star}$ & $2126.1^{\star}$ \\
1733.8 & 1733.9 \\
1686.4 & 1686.8 \\
1611.6 & 1611.5 \\
1559.9 & 1560.5 \\
1466.4 & 1466.5 \\
\hline
\end{tabular}

* Absorption of the diazo group

\section{UV-vis (HPLC)}

\begin{tabular}{|c|c|}
\hline Natural IPK (nm) & Synthetic IPK (nm) \\
\hline 218.1 & 211.0 \\
247.4 & 247.4 \\
284.0 & 284.0 \\
560.1 & 561.3 \\
\hline
\end{tabular}

Synthetic and natural isoprekinamycin exhibited the same $\mathrm{R}_{\mathrm{f}}$ values in the following three different solvent systems: $\mathrm{R}_{\mathrm{f}}=0.8($ EtOAc:Hexane $=3: 2), \mathrm{R}_{\mathrm{f}}=0.38\left(\mathrm{Et}_{2} \mathrm{O}:\right.$ Hexane $=1: 1), \mathrm{R}_{\mathrm{f}}=0.14\left(\mathrm{CH}_{2} \mathrm{Cl}_{2}:\right.$ Hexane $\left.=2: 1\right)$. 


\section{Comparison of ${ }^{1} \mathrm{H}$ NMR:}
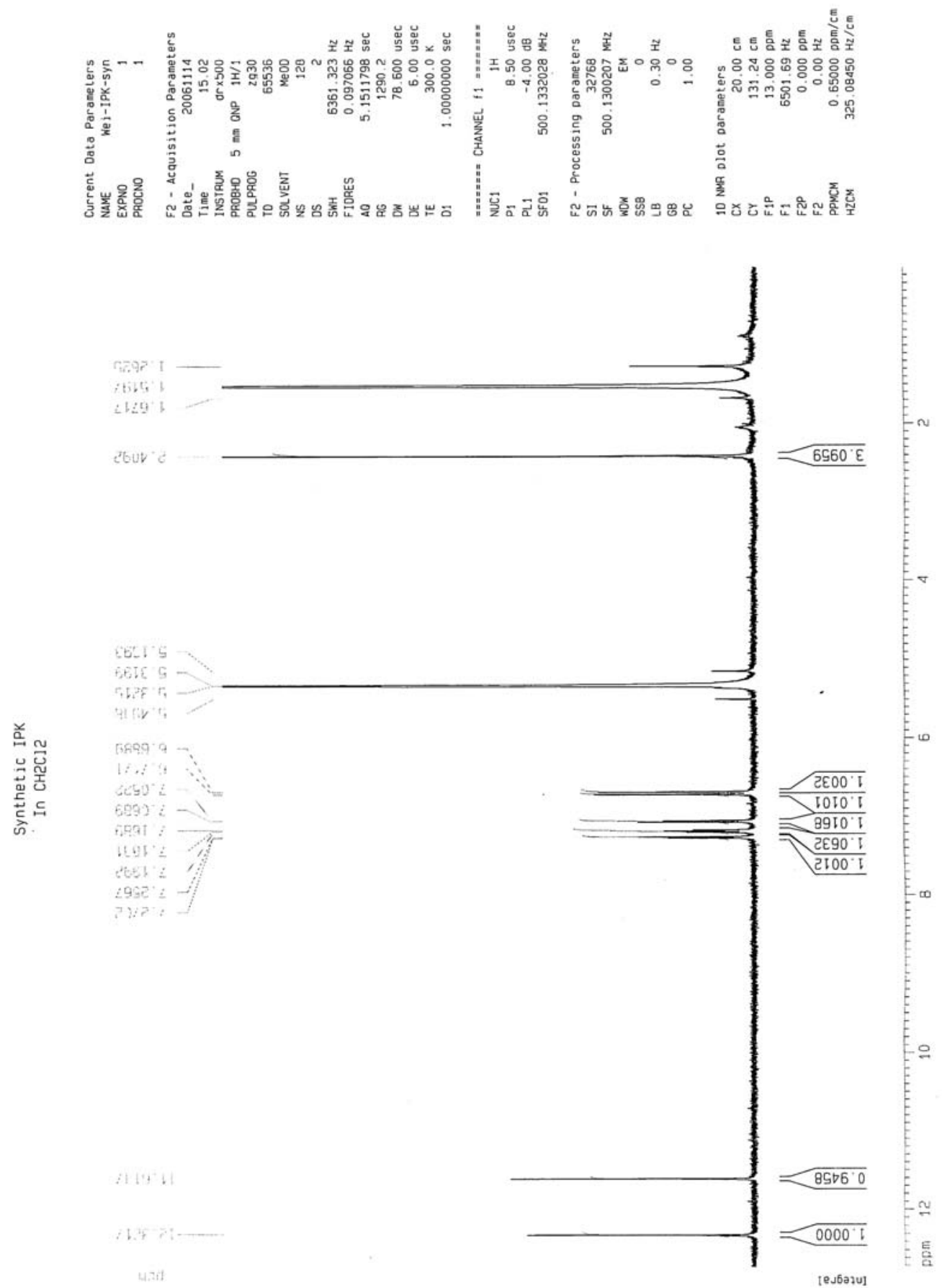

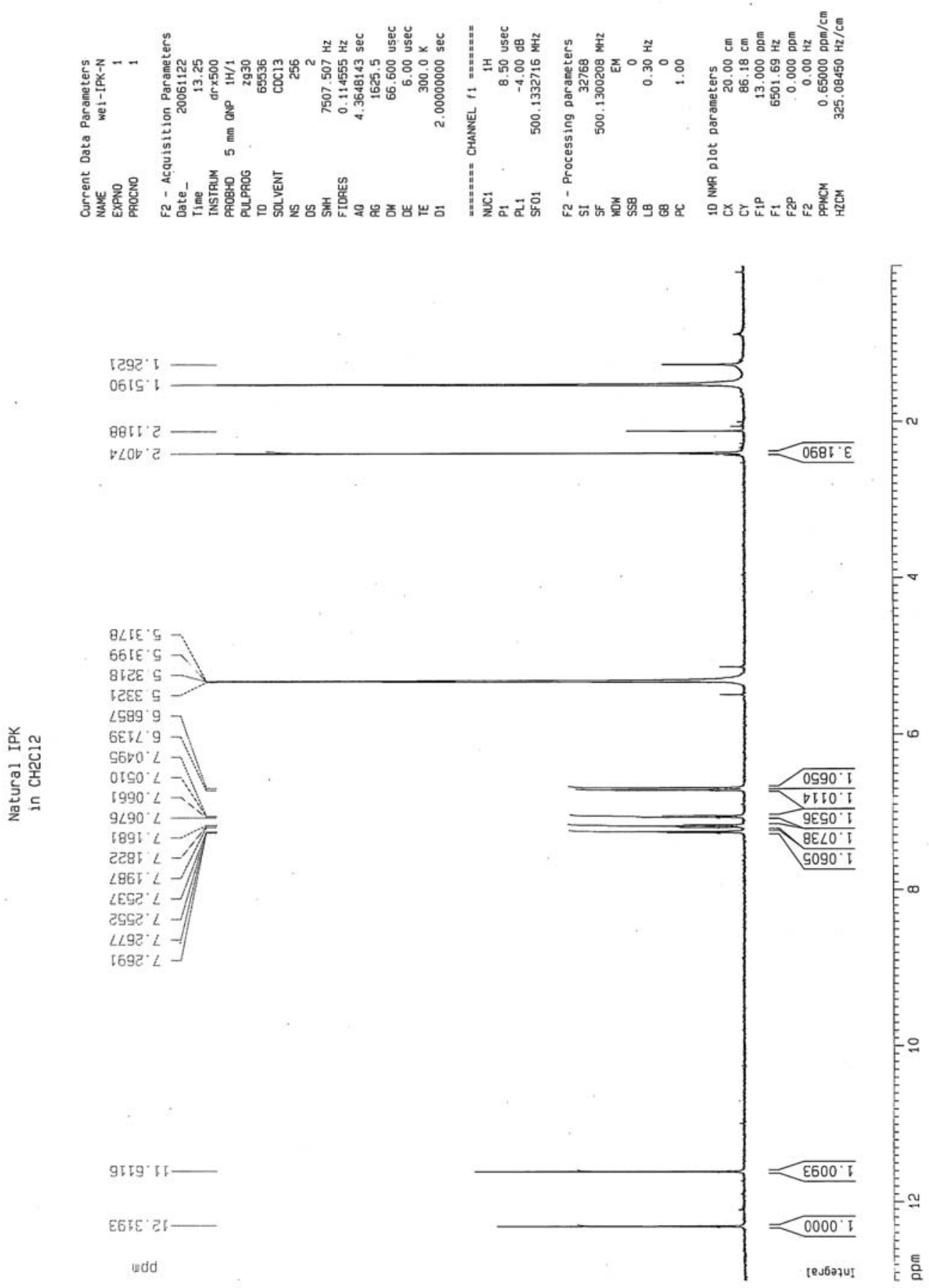


\section{Comparison of IR spectra:}

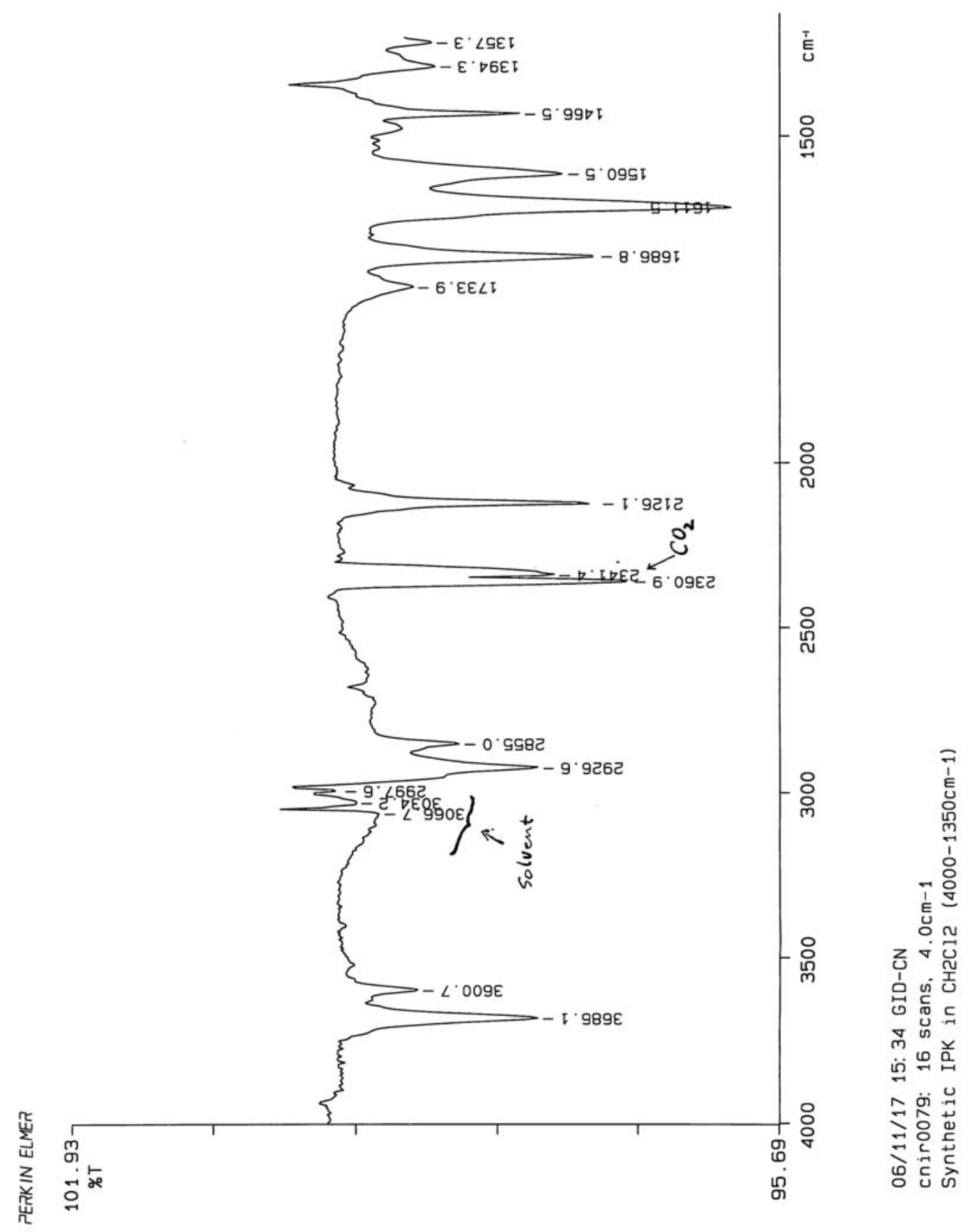




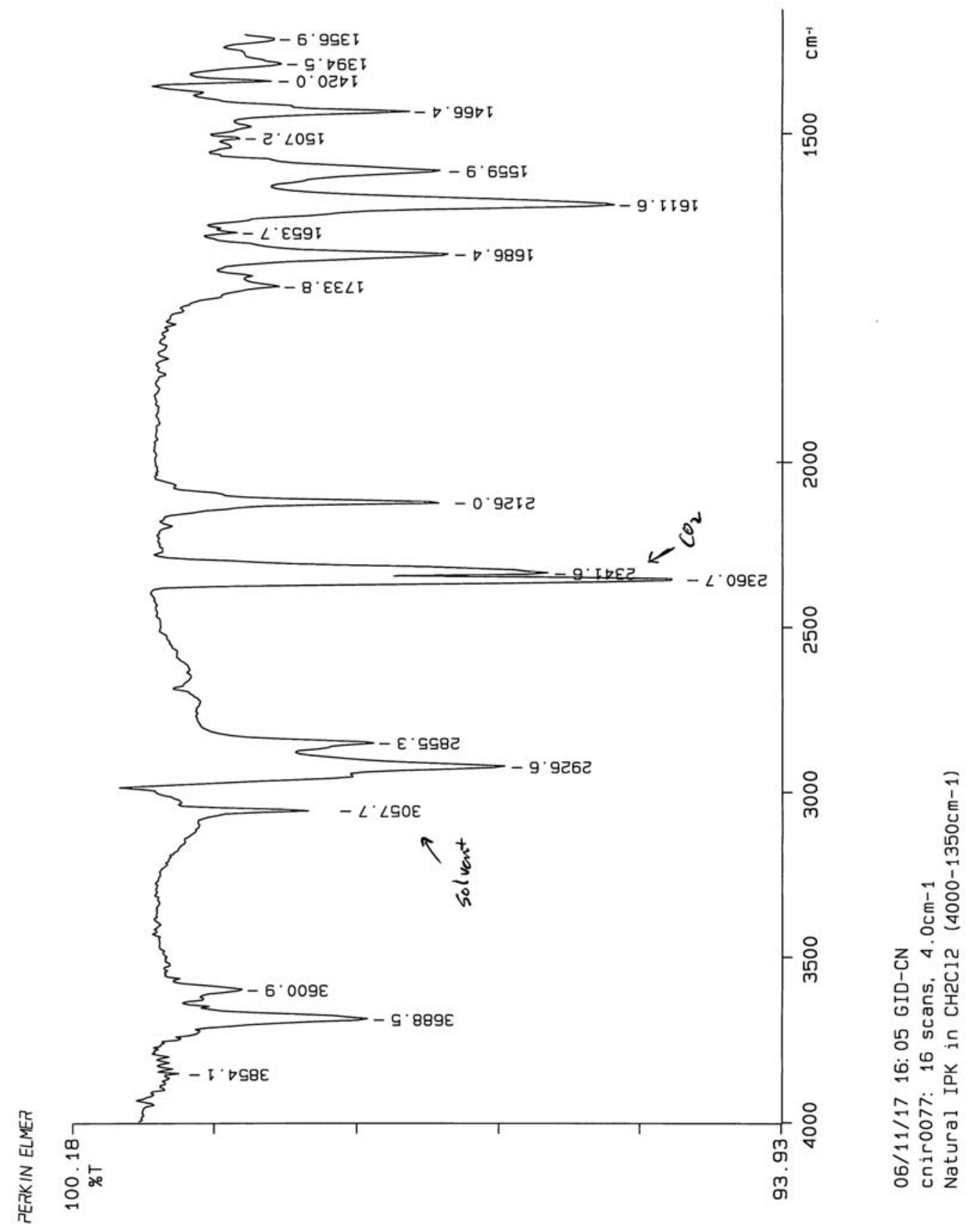




\section{Comparison of HPLC retention time:}
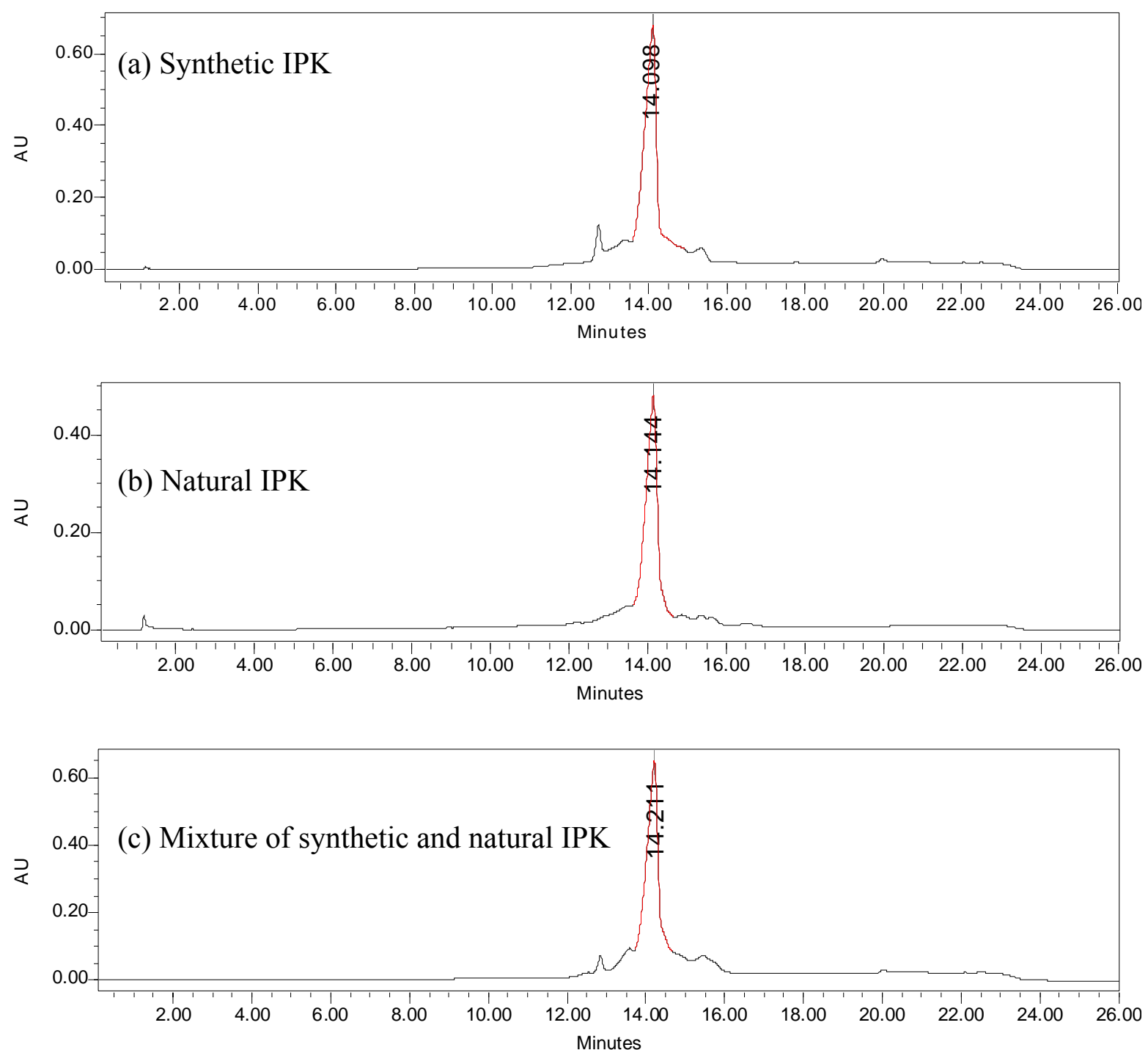

Figure 1. Comparison of the HPLC retention times of the synthetic and natural isoprekinamycin (IPK) with the following experimental setup and conditions: (1) HPLC system: Waters 600 controller, Waters 996 photodiode array detector, Waters Millennium ${ }^{\circledR}$ software; (2) Column: Nova-Pak ${ }^{\circledR}$ C18 $60 \AA 4 \mu \mathrm{m}, 3.9 \times 150 \mathrm{~mm}$; (3) linear gradient (20 minutes): $94 \% \mathrm{H}_{2} \mathrm{O}, 5 \% \mathrm{CH}_{3} \mathrm{CN}$ and $0.1 \% \mathrm{AcOH}$ to $5 \% \mathrm{H}_{2} \mathrm{O}, 94 \%$ $\mathrm{CH}_{3} \mathrm{CN}$ and $0.1 \% \mathrm{AcOH}$ at a flow rate of $1.5 \mathrm{~mL} /$ minute at room temperature. 


\section{Comparison of UV-vis spectra (HPLC):}
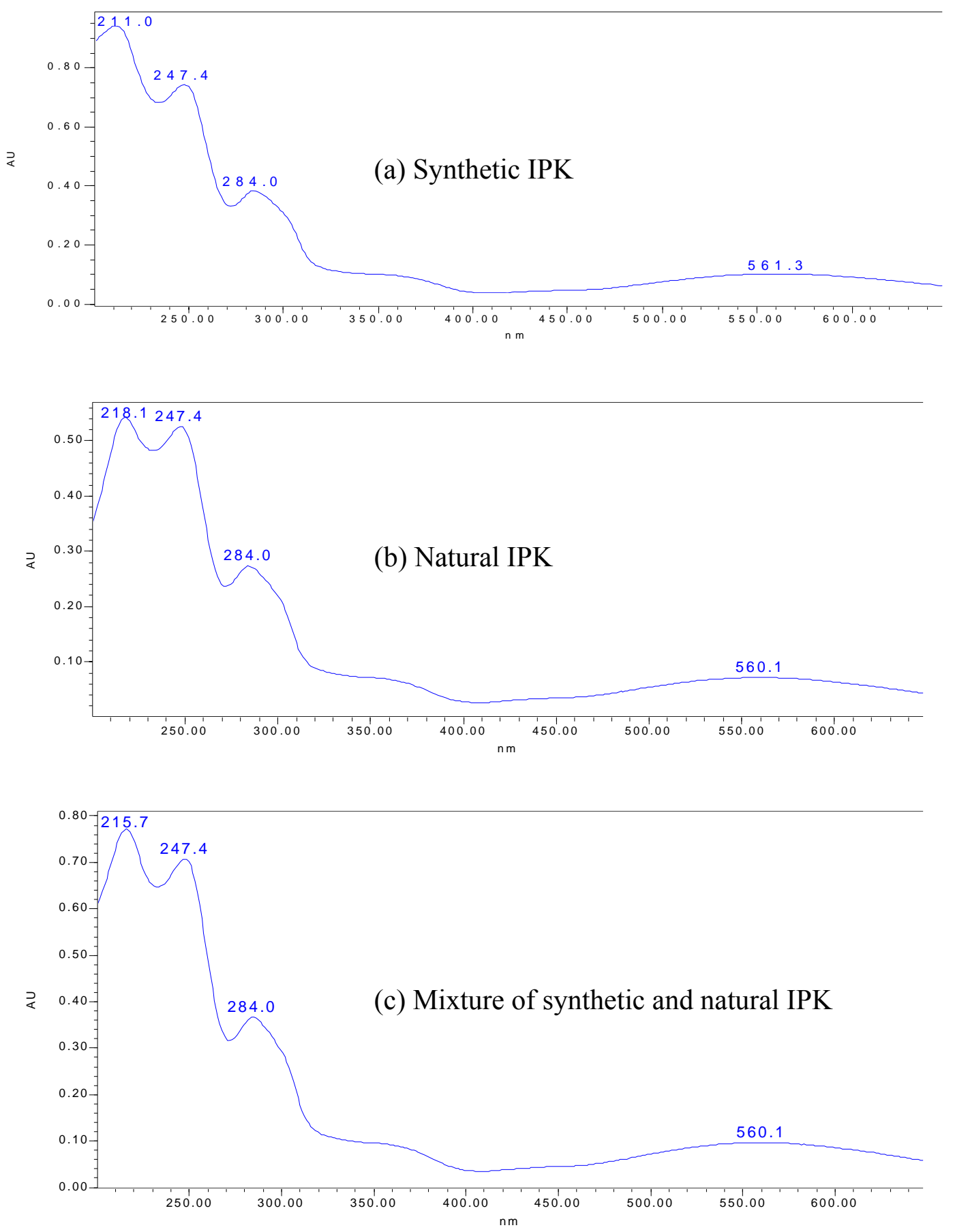

Figure 2. Comparison of the UV-vis spectra (recorded on the HPLC system) of the synthetic and natural isoprekinamycin (IPK). 


\section{III) Biological and Biochemical Assays}

\section{Methods and Materials}

Growth Inhibition Assays:

Unless indicated, all chemicals were from Sigma (Oakville, Canada). The 3-(4,5-dimethylthiazol-2-yl)-5-(3-carboxymethoxyphenyl)-2-(4-sulfophenyl)-2H-tetrazolium (MTS) CellTiter 96 \& AQueous One Solution Cell Proliferation Assay kit was obtained from Promega (Madison, WI, U.S.A.). The errors quoted are standard errors from non-linear least squares analysis (SigmaPlot, Systat, Point Richmond, CA).

\section{Cell culture and growth inhibition assays}

Chinese hamster ovary (CHO) cells (type AA8; ATCC CRL-1859), obtained from the American Type Culture Collection, were grown in alpha minimum essential medium ( $\alpha$-MEM; Invitrogen, Burlington, Canada) containing $20 \mathrm{mM}$ HEPES (4-(2-hydroxyethyl)piperazine-1-ethanesulfonic acid) as described. ${ }^{9}$ Human leukemia K562 cells, obtained from the American Type Culture Collection, were maintained as suspension cultures in DMEM (Invitrogen, Burlington, Canada) containing 10\% fetal calf serum (FCS) and $2 \mathrm{mM} \mathrm{L-glutamine.} \mathrm{The} \mathrm{spectrophotometric} \mathrm{96-well} \mathrm{plate} \mathrm{cell} \mathrm{growth}$ inhibition 3-[4,5-dimethylthiazol-2-yl]-2,5-diphenyl tetrazolium bromide (MTT) (for CHO cells) and MTS (for K562 cells) (Promega, San Luis Obispo, CA) assays, which measures the ability of the cells to enzymatically reduce MTT or MTS after treatment with various concentrations of drugs, have been described. ${ }^{10}$ The drugs were dissolved in DMSO. The final concentration of DMSO did not exceed $0.5 \%(\mathrm{v} / \mathrm{v})$ and was an amount that had no significant effect on cell growth. The cells were incubated with the drugs for 72 hours and then assayed with either MTT or MTS. IC $C_{50}$ values, the concentration of isoprekinamycin that reduces the absorbance of MTT or MTS by one-half, for growth inhibition in both assays were measured by fitting the absorbance-drug concentration data to a three-parameter logistic equation as described. ${ }^{9}$ 


\section{Topoisomerase II $\alpha$ kDNA decatenation inhibition assay}

A spectrofluorometric decatenation assay was used to determine the inhibition of

topoisomerase II $\alpha$ by IPK-diacetate as was done for kinamycin A and kinamycin C. ${ }^{10}$ kDNA consists of highly catenated networks of circular DNA. Topoisomerase II $\alpha$ decatenates kDNA in an ATP-dependent reaction to yield individual minicircles of DNA. The $20 \mu \mathrm{L}$ reaction mixture contained $0.5 \mathrm{mM}$ ATP, $50 \mathrm{mM}$ Tris- $\mathrm{HCl}(\mathrm{pH} \mathrm{8.0)}, 120 \mathrm{mM}$ $\mathrm{KCl}, 10 \mathrm{mM} \mathrm{MgCl} 2,30 \Phi \mathrm{g} / \mathrm{mL}$ bovine serum albumin, $40 \mathrm{ng} \mathrm{kDNA}$, test compound (0.5 $\mu \mathrm{L}$ in dimethyl sulfoxide) and $10 \mathrm{ng}$ of topoisomerase II $\alpha$ protein (the amount that gave approximately $80 \%$ decatenation). Using a high copy yeast expression vector, full-length human topoisomerase II $\alpha$ was expressed, extracted and purified as described previously. ${ }^{11}$ The final dimethyl sulfoxide concentration of $2.5 \%(\mathrm{v} / \mathrm{v})$ was shown in controls not to affect the activity of topoisomerase II $\alpha$. The assay incubation was carried out at $37{ }^{\circ} \mathrm{C}$ for 20 minutes and was terminated by the addition of $12 \mu \mathrm{L}$ of $250 \mathrm{mM} \mathrm{Na} \mathrm{F}_{2}$ EDA. Samples were centrifuged at $8000 \mathrm{~g}$ at $25^{\circ} \mathrm{C}$ for 15 minutes and $20 \Phi \mathrm{L}$ of the supernatant was added to $180 \Phi L$ of 600 -fold diluted PicoGreen ${ }^{\circledR}$ dye (Molecular Probes, Eugene, OR) in a 96-well plate. The fluorescence, which was proportional to the amount of kDNA, was measured in a Fluostar Galaxy (BMG, Durham North Carolina, USA) fluorescence plate reader using an excitation wavelength of $485 \mathrm{~nm}$ and an emission wavelength of $520 \mathrm{~nm}$.

\section{pBR322 DNA topoisomerase II-mediated cleavage assays}

Topoisomerase II-cleaved DNA complexes produced by anticancer drugs may be trapped by rapidly denaturing the complexed enzyme with sodium dodecyl sulfate (SDS). ${ }^{12}$ The cleavage of double-stranded closed circular pBR322 DNA to form linear DNA was followed by separating the SDS-treated reaction products using ethidium bromide gel electrophoresis as described. ${ }^{12}$ The $20 \mu \mathrm{L}$ cleavage assay reaction mixture contained 100 ng of topoisomerase II $\alpha$ protein or topoisomerase II nuclear extract, 80 ng pBR322 plasmid DNA (MBI Fermentas, Burlington, Canada), $0.5 \mathrm{mM}$ ATP in assay buffer (10 
$\mathrm{mM}$ Tris- $\mathrm{HCl}, 50 \mathrm{mM} \mathrm{KCl}, 50 \mathrm{mM} \mathrm{NaCl}, 0.1 \mathrm{mM}$ EDTA, $5 \mathrm{mM} \mathrm{MgCl}_{2}, 2.5 \%$ (v/v) glycerol, $\mathrm{pH} 8.0$, and drug $(0.5 \mu \mathrm{L}$ in dimethyl sulfoxide). The order of addition was assay buffer, DNA, drug, and then topoisomerase II $\alpha$. The reaction mixture was incubated at $37{ }^{\circ} \mathrm{C}$ for 10 minutes and quenched with $1 \%$ (v/v) SDS $/ 25 \mathrm{mM} \mathrm{Na} \mathrm{EDTA}_{2}$. The reaction mixture was treated with $0.25 \mathrm{mg} / \mathrm{ml}$ proteinase $\mathrm{K}$ (Sigma) at $55{ }^{\circ} \mathrm{C}$ for 30 minutes to digest the protein. The linear pBR322 DNA cleaved by topoisomerase II $\alpha$ was separated by electrophoresis ( 2 hours at $8 \mathrm{~V} / \mathrm{cm}$ ) on a TAE (Tris base $(4 \mathrm{mM}) /$ glacial acetic acid $(0.11 \%(\mathrm{v} / \mathrm{v})) / \mathrm{Na}_{2} \operatorname{EDTA}(2 \mathrm{mM})$ buffer $)$ ethidium bromide $(0.5 \mu \mathrm{g} / \mathrm{mL})$ agarose gel $(1.2 \%, w t / v)$. The DNA in the gel was imaged by its fluorescence on an Alpha Innotech Fluorochem 8900 imaging system.

\section{$\underline{\text { Results }}$}

\section{Isoprekinamycin-induced cell growth inhibition}

As shown in Figure 1, below, isoprekinamycin strongly inhibited growth of CHO cells and $\mathrm{K} 562$ cells with $I C_{50}$ values of 5.8 and $6.4 \mu \mathrm{M}$, respectively. These values compare to $I_{50}$ values of 1.4 and $3.4 \mu \mathrm{M}$, respectively for the widely used anticancer drug etoposide (data not shown).

Figure 1. Isoprekinamycin-induced growth inhibition of $\mathrm{CHO}(\mathrm{A})$ and $\mathrm{K} 562$ (B) cells. Attached CHO cells or suspension K562 cells were treated for 72 hours with a range of isoprekinamycin concentrations. The solid lines are three-parameter non-linear least squares calculated logistic fits of the MTT or MTS absorbance-isoprekinamycin concentration data and were used to obtain the $I C_{50}$ values. The error bars were calculated from replicates. 

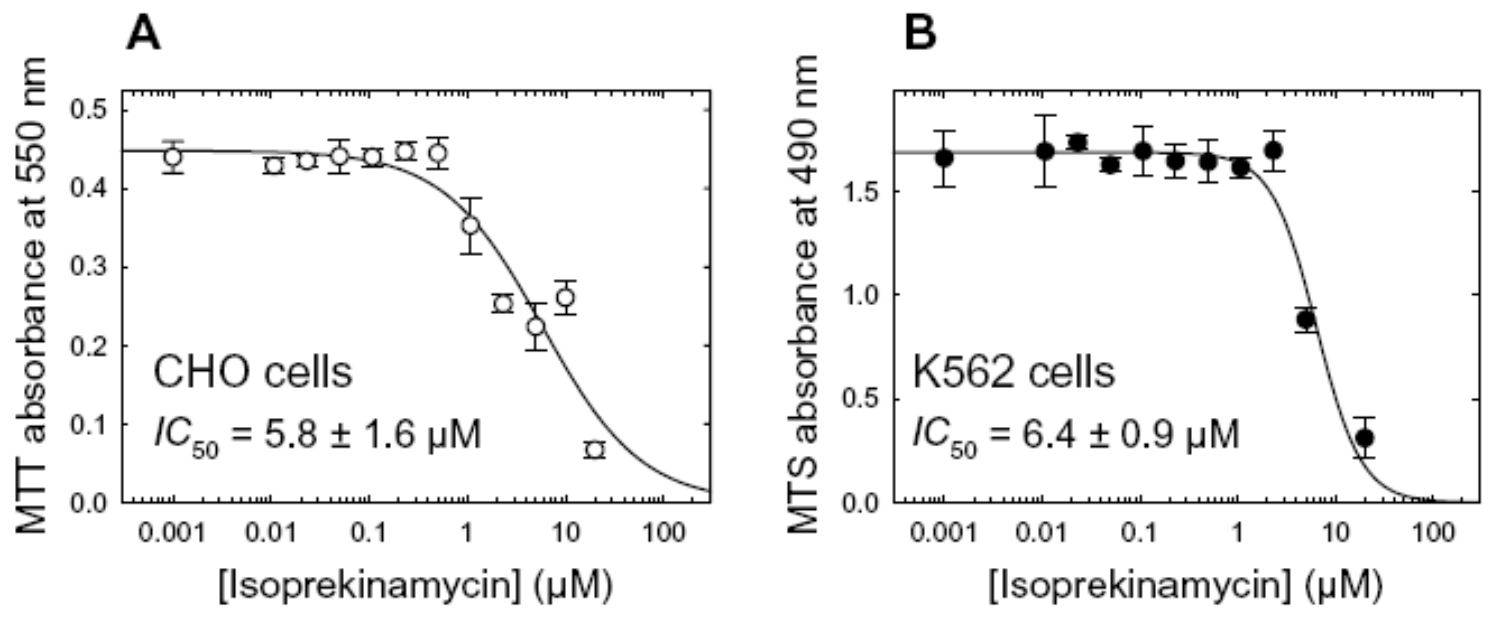

\section{IPK-diacetate inhibits the decatenation activity of topoisomerase II $\alpha$}

As shown in Fig. 2, below, IPK-diacetate strongly inhibited $\left(I C_{50}\right.$ value of $\left.9.7 \mu \mathrm{M}\right)$ the decatenation activity of human topoisomerase II $\alpha$. This assay is a measure of the ability of these compounds to inhibit the catalytic activity only and is not a measure of whether these compounds act as topoisomerase II poisons as do some widely used anticancer drugs. ${ }^{13,14}$ IPK up to a concentration of $120 \mu \mathrm{M}$ did not inhibit topoisomerase II (data not shown).

Figure 2. IPK-diacetate inhibits the decatenation activity of topoisomerase II $\alpha$. The ability of the compounds to inhibit the topoisomerase II $\alpha$-mediated decatenation of highly networked kDNA was measured in an ATP-containing assay mixture at $37{ }^{\circ} \mathrm{C}$ for 20 minutes. The fluorescence measures the amount of decatenated DNA minicircles in the supernatant of the centrifuged quenched $20 \mu \mathrm{L}$ assay mixture. IPK-diacetate inhibited the decatenation activity of topoisomerase II $\alpha$ with $I C_{50}$ values of $9.7 \pm 1.9 \mu \mathrm{M}$. The solid line is a non-linear least squares calculated fits of the fluorescence-concentration data to a three-parameter logistic equation. 


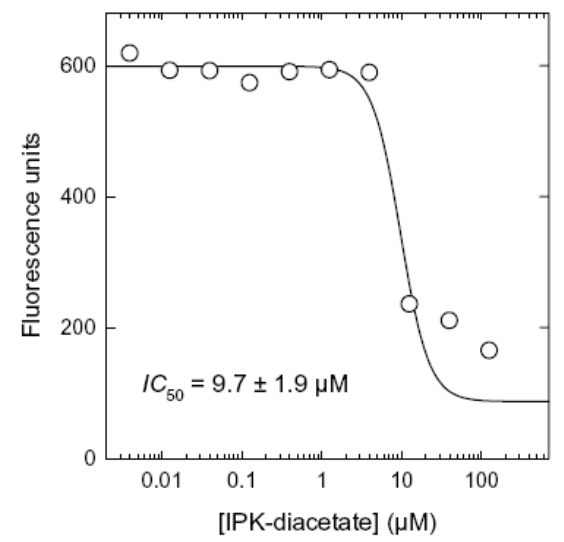

\section{Inhibition of topoisomerase IIa activity by IPK or IPK-diacetate was not accompanied by stabilization of the covalent topoisomerase II $\alpha$-DNA cleavable complex}

Several widely used anticancer agents, including etoposide, are thought to be cytotoxic by virtue of their ability to stabilize a covalent topoisomerase II-DNA intermediate (the cleavable complex). ${ }^{13,14}$ Topoisomerase II alters DNA topology by catalyzing the passing of an intact DNA double helix through a transient double-stranded break made in a second helix and is critical for relieving torsional stress that occurs during replication and transcription and for daughter strand separation during mitosis. ${ }^{13,14}$ Thus, DNA cleavage assay experiments as described ${ }^{4}$ were carried out using etoposide as a control to see whether the test compounds stabilized the cleavable complex. The addition of etoposide to the experimental mixture containing topoisomerase II $\alpha$ and supercoiled pBR322 DNA induced formation of linear pBR322 DNA. Linear DNA was identified by comparison with linear pBR322 DNA produced by action of the restriction enzyme HindIII acting on a single site on pBR322 DNA. The addition of up to $250 \mu \mathrm{M}$ IPK or $125 \mu \mathrm{M}$ of IPK-diacetate to the reaction mixture induced little or no detectable formation of cleaved linear pBR322 DNA (data not shown). 


\section{IV) References}

(1) Loudon, J. D.; Razdan, R. K. J. Chem. Soc. 1954, 4299-4303.

(2) Pang, J. ; Kozikowski, A. P. J. Org. Chem. 1991, 56, 4499-4508.

(3) (a) Littke, A. F. ; Dai, C.; Fu, G.. C. J. Am. Chem. Soc. 2000, 122, 4020-4028. (b) Netherton, M. R.; Fu, G. C. Org. Lett. 2001, 3, No. 26, 4295-4298.

(4) Katritzky, A. R.; Pilarski, B.; Urogdi, L. Synthesis 1989, 949-950.

(5) Moriarty, R. M.; Chany II, C. J.; Vaid, R. K.; Om Prakash; Tuladhar, S. M. J. Org. Chem. 1993, 58, 2478-2482.

(6) Ishii, Y.; Sakaguchi, S. Catal. Surv. Jpn. 1999, 3, 27-35.

(7) Baudoin, O.; Guénard, D.; Guéritte, F. J. Org. Chem. 2000, 65, 9268-9271.

(8) Kim, S. ; Ahn, K. H. J. Org. Chem. 1984, 49, 1717-1724.

(9) Hasinoff, B. B.; Kozlowska, H.; Creighton, A. M.; Allan, W. P.; Thampatty, P.; Yalowich, J. C., Mol. Pharmacol. 1997, 52, 839-845.

(10) Hasinoff, B. B.; Wu, X.; Yalowich, J. C.; Goodfellow, V.; Laufer, R. S.; Adedayo, O.; Dmitrienko, G. I., Anti-Cancer Drugs 2006, 17, 825-837.

(11) Hasinoff, B. B.; Wu, X.; Krokhin, O. V.; Ens, W.; Standing, K. G.; Nitiss, J. L.; Sivaram, T.; Giorgianni, A.; Yang, S.; Jiang, Y.; Yalowich, J. C., Mol. Pharmacol. 2005, 67, 937-947.

(12) Burden, D. A.; Froelich-Ammon, S. J.; Osheroff, N., Meth. Mol. Biol. 2001, 95, 283-289.

(13) Fortune, J. M.; Osheroff, N., Progr. Nucleic Acid Res. Mol. Biol. 2000, 64, 221-253.

(14) Li, T. K.; Liu, L. F., Ann. Rev. Pharmacol. Toxicol. 2001, 41, 53-77. 